UNIVERSIDADE DE SÃO PAULO

FACULDADE DE FILOSOFIA, LETRAS E CIÊNCIAS HUMANAS DEPARTAMENTO DE LETRAS MODERNAS

PROGRAMA DO CURSO DE PÓS-GRADUAÇÃO DE ESTUDOS LINGUÍSTICOS E LITERÁRIOS EM INGLÊS

Janice Gonçalves Alves

\title{
A TERCEIRIZAÇÃO DO ENSINO DE LÍNGUA ESTRANGEIRA EM ESCOLAS DE ENSINO FORMAL
}

SÃO PAULO 
UNIVERSIDADE DE SÃO PAULO

FACULDADE DE FILOSOFIA, LETRAS E CIÊNCIAS HUMANAS DEPARTAMENTO DE LETRAS MODERNAS

PROGRAMA DO CURSO DE PÓS-GRADUAÇÃO DE ESTUDOS LINGUÍSTICOS E LITERÁRIOS EM INGLÊS

\section{A TERCEIRIZAÇÃO DO ENSINO DE LÍNGUA ESTRANGEIRA EM ESCOLAS DE ENSINO FORMAL}

JANICE GONÇALVES ALVES

Dissertação de Mestrado apresentada à Banca Examinadora da Universidade de São Paulo, como exigência parcial para obtenção do título de mestre em Letras.

Agência financiadora: Capes

ORIENTADOR: PROF. ${ }^{a}$ DR. ${ }^{a}$ WALKYRIA MONTE MÓR 
Dedico este trabalho a Deus - minha verdade construída a partir de experiência e fé. 


\section{AGRADECIMENTOS}

Aos meus pais, Pedro e Jane, por me darem a oportunidade da vida e pelos valores que me ensinaram a preservar.

Ao meu esposo querido, Maninho, pelo companheirismo e incentivo constantes.

Aos meus queridos filhos, Felipe e Pedro, por serem minha inspiração, por me darem motivação e alegria, sempre.

À minha orientadora, Prof. ${ }^{a}$ Dr. $^{a}$ Walkyria, por sua dedicação, paciência e capacidade excepcionais que me incentivaram em cada passo deste trabalho.

À Prof. ${ }^{a}$ Dr. ${ }^{a}$ Marília Mendes Ferreira e à Prof. ${ }^{a}$ Dr. ${ }^{a}$ Nara Hiroko Takaki por suas valiosas contribuições, quando do exame de qualificação.

Ao Prof. Dr. Lynn Mário T. Menezes de Souza e à Prof. ${ }^{a}$ Dr. ${ }^{a}$ Anna Maria Carmagnani pela inspiração e conhecimento compartilhados durante as disciplinas assistidas e durante todo o processo de amadurecimento acadêmico.

Aos professores, alunos, coordenadores e diretora das instituições de ensino que me propiciaram a oportunidade de pesquisa em seus espaços.

Aos muitos amigos, antigos e novos, pelo incentivo e suporte durante o caminho.

À agência financiadora CAPES pelo apoio financeiro durante parte do período de pesquisa. 
BANCA EXAMINADORA 


\section{RESUMO}

Este trabalho tem como foco principal analisar o fenômeno da terceirização de ensino de língua estrangeira bem como suas respectivas práticas educacionais no contexto da educação formal.

Trata-se de uma pesquisa qualitativa-interpretativa de cunho etnográfico, realizada a partir de observações de aulas, entrevistas formais e informais com professores, alunos, coordenador e diretor em uma escola particular que pratica a terceirização do ensino de línguas com um instituto de idiomas. As concepções que embasaram as análises realizadas são as das teorias da pedagogia crítica (FREIRE, 1996; GIROUX, 1997) e dos letramentos e multiletramentos ( GEE, 1990; COPE e KALANTZIS, 1996; LANKSHEAR e KNOBEL, 2003).

As análises assinalaram que, sob um contexto neoliberal de mercantilização da educação, a terceirização do ensino de línguas foi uma alternativa que visa garantir a qualidade e a produtividade numa visão linguística estruturalista do que seria um ensino eficaz. No entanto, sob uma perspectiva voltada aos objetivos educacionais e de formação do estudante, pertinentes a uma visão de língua como prática social e um lugar onde valores são construídos, essa prática mostrou-se incompatível, considerando as mudanças percebidas na sociedade atual.

Palavras-chave: terceirização do ensino de línguas; pedagogia crítica; letramentos e multiletramentos; mercantilização da educação. 


\section{ABSTRACT}

This work focuses on analyzing the phenomenon of outsourcing foreign language teaching as well as their respective educational practices in the context of formal education.

It is a qualitative and interpretative ethnographical-oriented research held from observations of lessons, formal and informal interviews with teachers, students, Coordinator and Principal in a private school that practices the outsourcing of language teaching with a language Institute. The conceptions leading the analyses carried out are the theories of critical pedagogy (FREIRE, 1996; GIROUX, 1997) and literacy and multiliteracy studies (GEE, 1990; COPE and KALANTZIS, 1996; LANKSHEAR and KNOBEL, 2003).

The analysis has indicated that, under a neoliberal context of commodification of education, language teaching outsourcing has been an alternative which aims to ensure the quality and productivity in a structuralistic linguistic view of what should be an effective education. However, under educational objectives, relevant to a perspective of language as a social practice and a place where values are built, this practice has signaled to be incompatible, considering the changes observed in the nowadays society.

Keywords: outsourcing of foreign language teaching; critical pedagogy; literacy and multiliteracy; commodification of education. 


\section{SUMÁRIO}

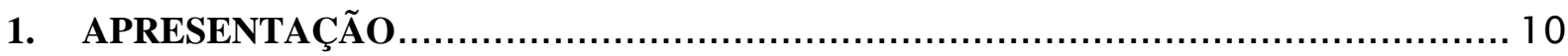

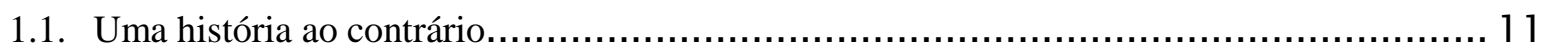

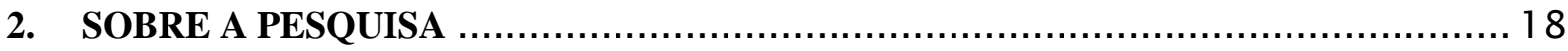

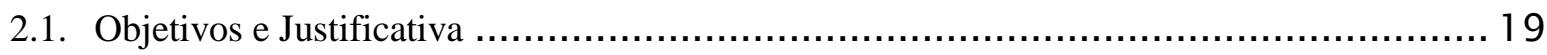

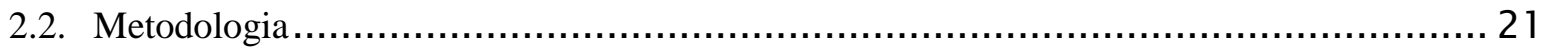

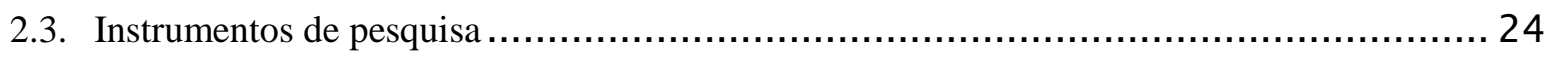

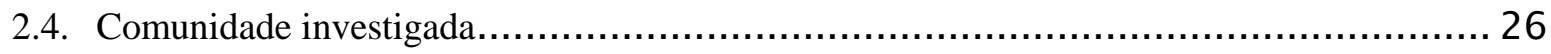

2.5. Em busca da harmonia dos dados: Prelúdio e Interlúdio. ................................... 29

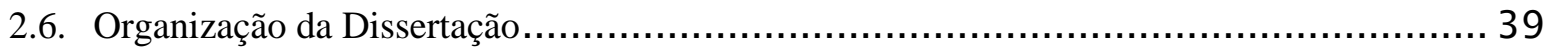

3. CAPÍTULO 1 - AS TEORIAS DOS NOVOS LETRAMENTOS ...................... 41

3.1. O Ensino de L.I. praticado nas últimas décadas ......................................... 41

3.2. Novos projetos de ensino de L.I. - O Ensino de L.I. em uma perspectiva educacional........ 46

3.3. Subsídios teóricos para proposta educacional de L.I......................................... 49

3.3.1. Panorama histórico............................................................... 49

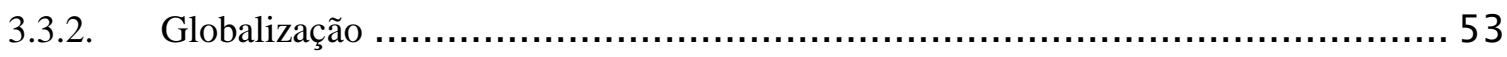

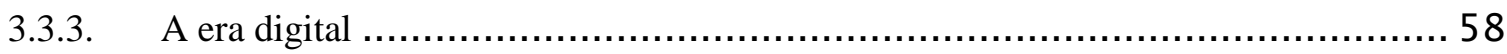

3.3.4. Os Multiletramentos e o ensino de língua estrangeira ................................. 61

\section{CAPÍTULO 2 - A TERCEIRIZAÇÃO DO ENSINO DE IDIOMAS: UMA PROPOSTA}

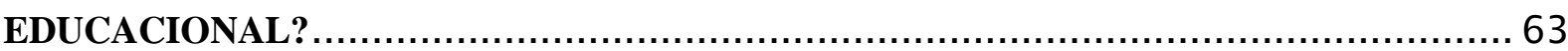

4.1. Neoliberalismo: contextualizando a terceirização do ensino de idiomas ...................... 63

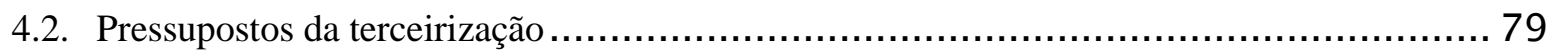


4.3. Os conflitos da terceirização

4.3.1. A influência da publicidade no contexto escolar: disseminação da terceirização do ensino de idiomas através da mídia. 86

4.3.2. Outros conflitos: analisando os objetivos 96

5. CAPÍTULO 3 - A PRÁTICA DA TERCEIRIZAÇÂO 102

5.1. Dificuldades para se lidar com a heterogeneidade na escola de educação formal; a padronização e o modelo

5.1.1. A quebra da homogeneidade e a presença de conflitos: uma possibilidade para a revisão de objetivos educacionais

5.2. A formação docente na parceria terceirizada: treinamento ou posicionamento crítico? ..... 120

5.2.1. A possibilidade de uma brecha na terceirização: a agência docente? 125

5.3. Análise das perspectivas atuais: a terceirização chega à escola pública.

6. CONSIDERAÇÕES FINAIS

7. REFERÊNCIAS BIBLIOGRÁFICAS

8. APÊNDICES

9. ANEXOS 


\section{A TERCEIRIZAÇÃO DO ENSINO DE LÍNGUA ESTRANGEIRA EM ESCOLAS DE ENSINO FORMAL}

\section{APRESENTAÇÃO}

Em boa parte da classe de professores de língua estrangeira, principalmente do Inglês, tem ocorrido uma incessante busca por metodologias, abordagens, materiais didáticos revolucionários, técnicas motivacionais inovadoras, tentativas de utilização das mais recentes tecnologias, enfim, o que é reconhecido como "receitas" que possam resolver a ineficácia do ensino de línguas na escola de educação formal.

Como professora de língua inglesa, trabalhando por vários anos em escolas de educação formal, incluo-me nessa classe de profissionais insatisfeitos com o resultado de seu próprio trabalho e sempre a procura de alguma inovação que pudesse resolver o "problema" do ensino de Inglês na escola.

Embora muitas vezes ciente de que estava tentando fazer um bom trabalho, participava meio que inconscientemente do discurso generalizado de que não se aprende inglês na escola de educação formal, que as soluções para o problema do ensino de inglês estavam fora daquela instituição.

Em uma dessas tentativas, a rede de escolas onde trabalhava, buscou a "solução" para o ensino de inglês de forma eficaz, fazendo uma parceria com um instituo de idiomas, de atuação conceituada no mercado de ensino de línguas. Esta parceria na verdade, era uma terceirização do ensino de inglês em todas as escolas da rede, visando tornar esse ensino mais eficaz, fidelizar os clientes (alunos e pais de alunos), tornando-os mais satisfeitos com essa disciplina, considerada um problema, até então.

Nesse processo de terceirização, entre as muitas mudanças estruturais ocorridas, alguns professores foram descartados porque não se adaptaram aos novos métodos propostos pelo instituto de idiomas que ora direcionaria as aulas de inglês. No meu caso, fui aproveitada e me mantive lecionando naquela instituição.

Foi assim, que durante dois anos, tive contato intenso com essa nova modalidade educacional, porque tive a visão de quem está dentro do processo, de como se efetuaria a terceirização do ensino de línguas.

Nesse processo, tive a oportunidade de conhecer toda a metodologia, o aparato tecnológico, o treinamento, os recursos didáticos, bem como a filosofia que permeava essa, 
até então, nova possibilidade de solucionar o fracasso do ensino de inglês das escolas de educação formal.

E foi assim que nas muitas idas e vindas das reuniões de reciclagem e avaliação junto ao instituto de idiomas, que nos altos e baixos do meu dia a dia com os alunos, nas muitas tentativas de tentar entender qual era o meu papel como educadora, surgiu a vontade de refletir sobre esse fenômeno da terceirização, que já havia se tornado bastante comum em muitas escolas particulares.

Esse foi o resumo do caminho percorrido por mim e de como cheguei à escolha do tema de minha dissertação. Ao ter a oportunidade de voltar aos bancos universitários, senti a necessidade de buscar algumas respostas, questionar algumas certezas, refletir sobre posições, enfim, pesquisar, para uma ação transformadora.

Portanto, o foco desta pesquisa é a análise do fenômeno da terceirização do ensino de inglês nas escolas de educação formal pelos institutos de idiomas, em seu formato intracurricular, ou seja, aquele no qual todas as prerrogativas educacionais ligadas a esse ensino ficam a cargo do instituto de idiomas, desde concepções pedagógicas, metodologia, professores e seu treinamento, bem como todo tipo de materiais didáticos.

\subsection{Uma história ao contrário}

Já na fase final de minha dissertação, ao repensar meu trajeto como pesquisadora, organizando os temas de cada capítulo, senti uma vontade, uma quase necessidade, de montar minha história; não como de praxe, num resumo introdutório para dar sentido ou justificar a escolha do tema, mas como uma espécie de catarse, que só agora, nesse momento quase final, surge como uma narrativa.

A propósito, há poucos dias por acaso, conheci o livro de literatura infantil de Ana Maria Machado (1996), Uma História Meio ao Contrário, o qual, parafraseio no subtítulo e de alguma forma na composição deste capítulo, em dois aspectos: primeiro, pelo fato de que, cronologicamente, essa vontade/necessidade de narrar meu percurso, veio ao contrário, quando já estou finalizando minha pesquisa, o começo perto do fim; e segundo, pelo fato de que ao interpretar minha trajetória, percebo que da mesma forma que a autora nesse conto desloca o famoso " e viveram felizes para sempre..." para o começo da história e o "era uma vez...", tradicional de todo início de conto de fadas, para o final, também estão deslocados 
dessa forma a minha experiência com a terceirização e toda a transformação que dela decorreu, meio ao contrário.

"E viveram felizes para sempre..." era justamente essa ideia que eu tinha diante da oportunidade de trabalhar em parceria com um instituto de idiomas numa escola de educação formal. Durante mais de dez anos de experiência como professora de inglês numa rede de escolas de educação formal bem conceituada, tive oportunidade de trabalhar com variadas turmas, da pré-escola ao ensino médio, passando por algumas fases de implementação de novidades e metodologias, que iam desde a euforia até a mais completa frustração.

Como rede, a escola sempre oferecia a oportunidade de cursos de reciclagem e de apoio pedagógico, com novidades e tendências de variados educadores, o que era bastante interessante, porque me ajudou a voltar a estudar, a ter contato com novas teorias e a interpretá-las de acordo com a minha realidade.

Lembro-me de uma determinada fase em que uma famosa educadora veio implementar uma nova tendência educacional na rede - o trabalho por projetos - que visava à interdisciplinaridade e à construção do conhecimento pelo aluno. A unidade onde eu trabalhava foi a escolhida para ser a primeira a desenvolver o trabalho por projetos, a partir do ensino fundamental II ( $5^{\mathrm{a}}$ a $8^{\mathrm{a}}$ séries ou $6^{\mathrm{o}}$ ao $9^{\circ}$ ano).

Fazíamos estudos e reuniões para compor os projetos de forma interdisciplinar e delimitávamos nossas ações definindo o passo a passo da implementação do projeto por cada professor. Numa dessas reuniões ficou definido o primeiro passo de implementação do projeto, que seria descobrir o tema a partir das ideias e interesses dos alunos e, a partir daí então, cada disciplina poderia desenvolver seus conteúdos. A educadora que nos orientava passou a dar vários exemplos de possibilidades de desenvolvimento de variados conteúdos em temas diferentes para cada disciplina. Comentou Matemática, ilustrou Física e Biologia, com Português, até Educação Física e Arte, mas não exemplificou nada na área de língua estrangeira. Pedi então, a ela, que me desse um exemplo para que eu pudesse ter uma ideia melhor de como seria minha atuação como professora de inglês, ao que ela respondeu, que sendo língua estrangeira apenas um ferramenta ${ }^{1}$, e que como a maioria dos alunos não tinha

\footnotetext{
1 Essa visão da língua de caráter instrumental é a base para muitas metodologias amplamente difundidas especialmente na década de 80 . No entanto, autores como Pennycook, Giroux, Fairclough, entre outros, têm a visão de língua como prática social além de ser também constitutiva dos sujeitos. Nos dizeres de Revuz (1996): "Muito antes de ser objeto de conhecimento, a língua é o material fundador de nosso psiquismo e de nossa vida
} 
nível linguístico para ir além do vocabulário básico, esta disciplina estaria "margeando" o projeto, e deu como exemplo de atividade a sugestão de "passar para o inglês" um texto coletivo produzido por qualquer outra área.

À margem - era exatamente assim que me sentia. Eu e milhares de professores de língua estrangeira, que viam seu papel de educador transformar-se em assessoria técnica; mas ao mesmo tempo, incapazes de dar conta de tal incumbência, a saber, ensinar uma língua estrangeira de forma eficaz e fluente, em condições de tempo e espaço consideradas pela maioria de nós, professores, como inadequadas e, apontada como um dos principais fatores para essa frustração.

Comentando sobre esse estado contraditório do professor, que ora se vê tolhido de sua agência como educador e ora assume sua culpabilidade diante do próprio fracasso, Carmagnani (2004) ressalta que os discursos que permeiam a sociedade é que acabam por constituir também o discurso do sujeito professor, que ora concorda com sua desmoralização como educador e ora resiste a essa culpa, especialmente fomentada pelos discursos da mídia. E ainda nos seus dizeres, esses discursos tornam-se em dispositivos de controle e de subjetivação, pois o sujeito-professor vai "de uma desejada agência ao assujeitamento, da resistência à docilização, do ser ao não-ser: movimentos contraditórios e, ao mesmo tempo constitutivos do sujeito; interdições que imobilizam e também são produtivas (CARMAGNANI, op. cit).

Essa passagem ilustra que eu me incluía nessa classe de profissionais que embora tentando fazer um bom trabalho, sentem-se insatisfeitos com os resultados e estão como que a procura de algo novo, uma metodologia, uma técnica, que possa resolver o "problema" do ensino de inglês na escola. Assim, acabei por participar meio inconscientemente do discurso generalizado de que não se aprende inglês na escola de educação formal, por conta das condições que tínhamos - duas aulas semanais, livro didático ultrapassado, falta de recursos tecnológicos, salas de 40 alunos, todos com níveis linguísticos muito diferentes - embora nunca além do básico - e que, portanto, as possibilidades de alguma solução para o problema do ensino de inglês, deveria estar fora daquela instituição.

Essa visão, também compartilhada pela direção da escola, acabou por facilitar um processo de mercantilização do ensino que já vinha sendo implementado por outras escolas da

relacional. Se não se escamoteia essa dimensão, é claro que não se pode conceber a língua como um simples instrumento de comunicação" (p. 217 ). 
rede, especialmente no interior, acabou chegando à minha unidade. Nessa ocasião, o diretor de minha unidade chamou-me para comentar sobre a possibilidade de realizar uma parceria com um instituto de idiomas, de atuação conceituada no mercado de ensino de línguas, querendo saber qual era a minha opinião, já que era uma professora com uma certa experiência, em cujo trabalho ele parecia confiar.

Nessa ocasião, vislumbrei uma possibilidade de solução para o "problema" do ensino de língua estrangeira naquela escola, pois ao mostrar-me o prospecto de venda da parceria, estavam ali, justamente alguns dos fatores que eu julgava serem os "culpados" pelo suposto fracasso do ensino. As "soluções" previstas eram a montagem de um laboratório de línguas com a utilização de um aparato tecnológico de ponta, que iam desde fones individuais, TV e DVD, até um pequeno centro multimídia, além de material didático especialmente elaborado e que garantiam uma metodologia eficaz, e além de tudo isso, um treinamento mensal organizado pela equipe pedagógica do instituto de idiomas parceiro, com todos os professores das unidades que fizessem a parceria.

Esse seria um plano para ser implantado no próximo ano, mas naquele mesmo final de ano as salas já começaram a ser reformadas e reestruturadas para se transformarem no English $L a b$, em várias unidades da rede onde a parceria foi comprada. Além disso, todos os professores de inglês dessas unidades foram submetidos a testes escritos, orais e entrevistas, junto ao pessoal do instituto de idiomas. Alguns professores não puderam ser "aproveitados" depois dessa triagem e foram dispensados, sendo alegado que eles não se adequavam às novas exigências da metodologia utilizada, segundo a equipe pedagógica da parceria.

E assim, no ano seguinte, começava uma história de terceirização, que para mim, tinha um sabor de "e viveram felizes para sempre..."

Embora bastante animada e envolvida com a parceria, imaginava que haveria alguma necessidade de adaptação tanto de minha parte quanto dos meus alunos. Logo a princípio soube que uma das adaptações seria o fato de que a divisão em níveis proposta pelo instituto no momento da parceria, não seria feita por questões de custo. Embora essa fosse uma das características do pacote de implementação, eles aceitaram essa questão, alegando que todos começariam do básico adaptado a cada série e assim iriam progredindo.

As duas aulas semanais eram realizadas no English Lab que constava de uma ampla sala de aula adaptada com oito mesas redondas de quatro lugares, as quais possuíam quatro fones individuais no centro, e mais uma mesa onde havia um computador com quatro lugares 
também, além de fones para a realização de exercícios com CD-ROM. Havia também aparelho de TV e DVD, além de uma lousa branca.

Os livros, reproduzidos e fornecidos pelo instituto de idiomas, eram na verdade, uma coleção antiga (uma edição de mais ou menos sete anos anteriores) de renomada editora, a qual havia vendido os direitos de reprodução para aquele instituto. Preparados originalmente para cursos livres em institutos de idiomas, os livros não tiveram nenhuma adaptação ou revisão de conteúdo, sendo apenas divididos em duas partes (A e B) para que se pudesse dar conta daquele conteúdo em duas aulas semanais.

Os treinamentos de professores eram realizados mensalmente, onde os professores terceirizados de determinada região da rede de escolas reuniam-se com uma equipe pedagógica do instituto de idiomas. Nessas reuniões revíamos o passo a passo de cada aula e a utilização do material, além disso, éramos solicitados a preparar uma determinada unidade do livro, e assim, apresentá-la, para logo após ter uma avaliação da equipe, com vistas a corrigir possíveis diferenças de interpretações de uso do material e de aplicação da metodologia.

Tínhamos também uma visita mensal de supervisores do instituto, que apareciam de surpresa para assistir um dia de nossas aulas. Nessas visitas também havia uma avaliação pessoal, além da verificação da adequação da agenda de aulas, a qual deveria ser rigorosamente seguida.

As aulas deveriam transcorrer dentro de um molde desenhado pelo livro, constando de um warm up com um vocabulário básico, texto com listening e reprodução oral. Essas atividades eram dirigidas pelo professor a toda a turma, que tinha em média 40 alunos, os quais eram dispostos em grupos de quatro, nas mesas com seus respectivos fones. Depois dessas atividades, todas as outras que iam desde a reprodução de diálogos, exercícios de estrutura gramatical, até pequenas produções, eram feitas nos grupos ao mesmo tempo, em formato de rodízio, até que todos tivessem passado por cada etapa, inclusive os exercícios na estação multimídia. Cabia ao professor auxiliar cada grupo nas atividades diferentes, avaliar a participação individual, além de ficar muito atento com a utilização adequada dos aparelhos, que eram de nossa responsabilidade.

A princípio, os alunos ficaram muito empolgados com as novidades tecnológicas, que à época eram atraentes, as quais rapidamente foram se desgastando com o passar dos dias e acabaram por se tornar um empecilho à manutenção da disciplina e da atenção por parte dos alunos durante as aulas. As limitações de tempo das atividades eram bastante rígidas e o uso 
dos aparelhos também era limitado, o que muitas vezes gerava a sensação de insatisfação, pois eles queriam sempre explorar mais.

Participei com muito empenho de todas as reuniões e dediquei bastante tempo e muita energia durante a preparação e realização das aulas. Aliás, energia era a necessidade número um diante de uma turma de $6^{\text {a }}$ série, por exemplo, dividida em grupos de quatro, cada um fazendo uma atividade diferente, as quais eu tinha que instruir e avaliar, além de manter todos os aparelhos intactos.

Com o passar do tempo, foi acontecendo um grande desgaste, tanto em nível disciplinar quanto em nível de cobrança, que a esta altura vinha de todas as frentes: as usuais cobranças dos pais de alunos que haviam criado grande expectativa em relação às novidades implantadas, e também da direção da escola em relação ao retorno do investimento realizado; porém, mais e, principalmente, por parte do instituto, que de forma direta interferia na atuação de cada professor.

Apesar de algumas frustrações aqui e ali, prosseguia, repetindo para mim mesma, que algumas adaptações eram mesmo necessárias e, perseguia então, o ideal do conto de fadas de ser feliz para sempre junto à parceria...

Numa determinada aula, uma dupla de supervisores chegou de surpresa para assistir minhas aulas, como já era de costume. A turma era uma $5^{\mathrm{a}}$ série com mais de quarenta alunos e estávamos na etapa de atividades diversificadas nos grupos. Muitos grupos solicitavam a minha presença ao mesmo tempo, problemas paralelos aconteciam, enquanto outros grupos tentavam fazer outras coisas alheias à aula, e houve até algum problema em relação aos aparelhos. E então, uma das supervisoras, a qual era a coordenadora geral das terceirizações, resolveu interferir. Pediu-me licença para conversar com os alunos e passou a proferir uma "palestra' de mais ou menos uns vinte e cinco minutos. Sua fala girava em torno da oportunidade de ascensão social de vida, que ora eles desperdiçavam por não aproveitarem as aulas para aprender inglês "de verdade". Entre seus exemplos de vida, para tentando um "choque reflexivo", expôs que, pelo caminho ao vir para a escola, tinha visto alguns meninos como eles, morando embaixo de uma ponte, e indagava se era esse tipo de futuro que queriam escolher. Além disso, citou a profissão de lixeiro como exemplo, para incentivá-los a aproveitar a oportunidade de aprender inglês "de verdade" que lhes estava sendo oferecida, e de como tudo isso lhes proporcionaria melhorias sociais e profissionais no futuro.

Confesso que, embora eu nunca tivesse lido uma linha sequer da pedagogia crítica de Giroux ou Pennycook, mas eu já havia lido Paulo Freire, aquilo me chocou, fazendo-me 
refletir que aquilo tudo poderia ser muito mais do que uma posição pessoal daquela pessoa, pois ela tinha total influência nas decisões e objetivos daquela instituição. Além disso, aquele discurso não estava de acordo com alguns ideais educacionais que eu procurava manter, mesmo muitas vezes sentindo-me à margem do processo - como aquela outra educadora dos projetos me fez crer - de construção da criticidade e percepção dos meus alunos.

$\mathrm{Na}$ fala daquela supervisora podemos perceber o discurso ideológico que permeia as instituições sociais do último século, as idéias neoliberais que redefinem a natureza de valores políticos e sociais, fundamentadas na economia de mercado. Giroux (2006) declara que essa fé num futuro melhor e essa possibilidade sustentável de ascensão social é apresentada como uma das duas tarefas do neoliberalismo: treinar trabalhadores para os empregos vigentes e produzir consumidores leais por toda a vida.

Dentro dessa mesma perspectiva, Althusser (1971) argumenta que as escolas representam um importante local para a reprodução das relações de produção capitalistas. Através da reprodução de habilidades e regras de trabalho definidas muitas vezes dentro do contexto do próprio currículo formal, o mesmo autor afirma que os estudantes aprendem o tipo de conhecimento que valida essas relações de produção, bem como as regras de ordem estabelecidas pela dominação de classes.

Esse episódio foi muito marcante para mim, pois me fez de alguma forma, refletir em toda aquela prática metodológica, que até então me parecia a resposta que conduziria a um ensino eficaz e produtivo. Comecei a desconfiar das minhas próprias práticas e de como elas poderiam estar reproduzindo nos meus alunos, sem nenhuma possibilidade de reflexão crítica, alguns valores da sociedade nos quais eu não acreditava.

E pouco a pouco, o castelo da terceirização começou a desmoronar para mim...

Relato a seguir, outro episódio que também contribuiu para que eu refletisse sobre algumas das minhas "certezas educacionais". Numa certa reunião mensal de treinamento, nas quais eu participava juntamente com o grupo de professores de inglês terceirizados, após a apresentação de um dos professores, na hora da avaliação de sua atuação sobre alguns pontos da aula, pronunciei-me sugerindo a possibilidade de vincularmos alguns temas transversais citados nos PCNs (1998) que fossem gerados por algumas unidades do livro. Nessa ocasião, estavam presentes duas coordenadoras do instituto de idiomas (uma delas, aquela do discurso de ascensão social para a $5^{\mathrm{a}}$ série), além da diretora geral, que por sinal era uma das sócias proprietárias do instituto, cuja sede era no interior de São Paulo, e que naquela data, avançava 
para a capital, através das franquias e também das terceirizações dentro das escolas formais, como no nosso caso.

Ao final da reunião, a diretora geral procurou-me para que eu esclarecesse a ela, a minha sugestão anterior, pois ela não sabia o que eram PCNs e do que tratavam. Fiquei bastante surpresa com essa declaração, porque imaginava que uma instituição que previa a educação em língua estrangeira, tivesse uma base fundamentada em alguns conhecimentos teóricos que aquele documento continha. Contei-lhe rapidamente o que conhecia sobre o documento, pois havia estudado parte do mesmo nas reuniões pedagógicas em minha unidade escolar, juntamente com todos os outros professores de outras disciplinas, dirigidos pela orientadora pedagógica da escola. Ela contou-me então, que havia uma equipe de assessoria didática que estava trabalhando na composição de um novo material didático para o instituto, e que gostaria que eu fosse participar de uma reunião com eles para falar-lhes sobre PCNs, o que não aceitei, pois não me sentia preparada para isso.

E assim, mais alguns tijolinhos do meu castelo com a terceirização caíram por terra.

Por mais algum tempo, tantas outras experiências, por vezes bastante desgastantes, foram desconstruindo meu castelo de certezas, alicerçado no desejo de ser o outro, o instituto de idiomas, achando que ele tinha os fundamentos que acabariam com as minhas frustrações enquanto professora de inglês.

Ao final de dois anos de trabalho com a terceirização, deixei todas as aulas do ensino Fundamental I e II, as quais faziam parte da parceria com o instituto de idiomas, ficando com as aulas do Ensino Médio, que não participava da terceirização.

Embora consciente da impossibilidade de neutralidade da linguagem em qualquer relato, nessa minha narrativa, não tive como objetivo julgar ou avaliar questões metodológicas ou mesmo filosóficas em relação à terceirização. Intencionei, outrossim, rever o caminho percorrido para explicitar o meu locus de enunciação, de onde falo e de como cheguei à escolha do tema de minha dissertação.

A partir desse ponto, senti a necessidade de buscar respostas, questionar certezas, refletir sobre posicionamentos e, ao ter a oportunidade de voltar à universidade, de pesquisar, e assim, de continuar a contar e recontar a história.

Era uma vez...

\section{SOBRE A PESQUISA}




\subsection{Objetivos e Justificativa}

O ensino de línguas deve propiciar ao aluno a oportunidade de engajamento e interação no mundo social (acadêmico, científico, tecnológico, humano), e também permitir o contato com outras civilizações e culturas, competência enfatizada como um dos principais eixos do ensino (FAIRCLOUGH, 1989). Devem ser observadas as diferenças de valores e costumes que permeiam a linguagem, podendo o entendimento dessas diferenças interferir de forma positiva ou negativamente na comunicação e harmonia entre os povos ou até mesmo entre os grupos sociais de um país, pois a linguagem é usada no mundo social como reflexo e como lugar de formação de crenças e valores. Esse enfoque social do ensino de língua permite uma melhor compreensão da importância da percepção da pluralidade cultural que hoje deve direcionar o seu ensino (op. cit.).

Embora o conhecimento de línguas estrangeiras seja altamente prestigiado na sociedade em geral, como disciplinas, parecem encontrar-se deslocadas da escola. A proliferação de cursos particulares, o fenômeno das parcerias de escolas de educação formal com institutos de idiomas, são evidências desse fato.

Há muitos que postulam a melhoria do ensino de língua estrangeira nas escolas regulares através da prática das parcerias com escolas de idiomas; fazem-no, baseando-se na retórica da educação com qualidade, sem a abordagem dos aspectos ideológicos e políticos que subjazem a esses discursos, os quais, não só simbolicamente ou terminologicamente, podem indicar uma prática política e social concreta. Não omitimos com isso a necessidade da qualidade no ensino de língua estrangeira, mas trata-se de, nas palavras de Gentili (1999), “construir um novo sentido que leve a qualidade da educação ao status de direito inalienável que corresponde à cidadania, sem nenhum tipo de restrição ou segmentação de caráter mercantil" (op. cit. p.172).

Em se tratando do discurso da qualidade, alguns aspectos do Neoliberalismo, cenário econômico e social do fenômeno em questão, contribuiram ao longo de sua implantação e história, na criação de condições favoráveis para um progressivo abandono dos discursos democratizadores no campo educativo, decorrendo num processo de transposição, onde a qualidade e a educação passaram a ser encaradas como na lógica produtivista mercantil, como no âmbito empresarial (GENTILI, 1997). Essa questão será expandida mais adiante. 
Um dos aspectos destacados na pesquisa é a investigação sobre a compatibilidade da visão de ensino privado, das escolas de idiomas, com a visão educacional do ensino formal de língua estrangeira das escolas de educação regular, em termos de objetivos.

Sendo assim, a investigação compara e também contrasta, as escolas de idiomas, estruturadas de forma concentrada na disciplina única "línguas estrangeiras", as quais certamente têm seu espaço e valor na sociedade, focalizando seus objetivos no aspecto linguístico ou instrumental da língua, com a escola de educação formal, pública ou particular, cujos objetivos devem assumir um caráter formativo em interação com o conjunto das disciplinas.

Esse estudo comparativo e contrastivo sustenta-se nas pesquisas de estudiosos dessa área, na educação formal. Segundo esses, o aspecto linguístico do ensino de língua estrangeira não deveria se sobrepor à função educacional, a qual deve ser prioritária (OCEM, 2006). Entendemos aqui como função educacional o trabalho reflexivo e crítico com os aspectos sociais, culturais, políticos e ideológicos, os quais devem estar inseridos no estudo de línguas.

$\mathrm{Na}$ proposta de revisão dos objetivos educacionais do ensino de línguas, conforme encontramos nas OCEM (2006), ganha muita relevância a educação geral do estudante como indivíduo e como cidadão, tornando-o capaz de ter uma visão de mundo reflexiva e crítica, para assim, conseguir situar-se dentro da sociedade, sabendo o seu lugar nela, compreendendo porque está ali. Esse aluno-cidadão deverá entender também a possibilidade e eventuais limitações de deslocamento a partir de suas escolhas e contribuir para a formação e transformação da comunidade em que vive.

Com base nessas perspectivas, tornam-se objetivos desta investigação:

a) Identificar e analisar os objetivos educacionais formativos previstos pelas escolas formais quando estas praticam o ensino de idiomas no formato terceirizado.

b) Analisar a prática de terceirização do ensino de língua estrangeira e suas respectivas práticas educacionais no contexto da educação formal.

Em função desses objetivos formulei a seguinte pergunta de pesquisa:

A terceirização do ensino de língua estrangeira é compatível às expectativas desse ensino na escola de educação formal?

A justificativa para essa pesquisa se deve ao fato de ela concentrar-se numa questão observada há poucos anos em escolas da cidade de São Paulo, uma ocorrência para a qual encontram-se poucos estudos acadêmicos até o momento. Entende-se que a contribuição deste trabalho seja identificada na abordagem dos vários aspectos localizados na questão aqui 
proposta, a presença do ensino terceirizado de línguas estrangeiras na escola de educação formal, e a análise da mesma no que concerne aos objetivos de ensino/aprendizagem de idiomas estrangeiros na escola de ensino fundamental e médio, da adequação da mencionada proposta de terceirização aos propósitos educacionais previstos nas escolas regulares.

Pretende-se que esta pesquisa represente uma expansão de perspectiva a respeito da temática focalizada, propiciando visão reflexiva e crítica aos estudiosos dessa área.

\subsection{Metodologia}

A construção deste trabalho de pesquisa pretende realizar-se a partir de análises qualitativas, de cunho etnográfico, segundo as bases teóricas interpretativas de Geertz (1987).

Fazer etnografia, em uma linha semiótica segundo Geertz (1987), equivale a uma análise antropológica como forma de conhecimento. Vale ressaltar que não se trata de uma questão de métodos; etnografia não se resume em métodos para estabelecer relações, selecionar informantes, transcrever textos, estabelecer genealogias, traçar mapas da área, manter um diário, etc. Esses são os procedimentos para se chegar àquilo que Geertz (1987), apoiando-se em Gilbert Ryle chama de "descrição densa". A descrição densa define o objeto da etnografia; parafraseando Geertz, uma hierarquia estratificada de estruturas significativas entendendo-as onde elas se produzem e como se produzem.

O autor ainda declara que aquilo que chamamos de dados, na verdade são interpretações de interpretações de outras pessoas sobre o que elas e seus compatriotas pensam e sentem. Portanto, dados são interpretações de interpretações. O que o etnógrafo faz na realidade, é encarar uma multiplicidade de estruturas complexas que são ao mesmo tempo estranhas, irregulares, não explícitas, às quais o etnógrafo deve apropriar-se de alguma maneira, para primeiro captá-las e depois entendê-las.

Segundo Fonseca (1998), muitas pessoas têm procurado na antropologia, especialmente no método etnográfico, uma saída para as tipologias massificantes e teorias abstratas, tentando fechar a lacuna entre a teoria e a realidade. Para estas, o método etnográfico parece uma técnica ao alcance de praticamente todo mundo, garantindo a interação entre o pesquisador e seu objeto de estudo, com ênfase no cotidiano e no subjetivo, com uma técnica investigativa para combater os males da quantificação.

Fonseca (1998), como antropóloga na linha semiótica de Geertz, acredita que além de ser um instrumento importante para a compreensão intelectual de mundo, também pode ter 
uma utilidade prática. Especificamente na educação, onde o sucesso depende do diálogo estabelecido entre o agente e seu interlocutor, a metodologia de pesquisa pode atuar.

Sob essa perspectiva de atuação da etnografia especificamente no campo educacional, André (2003) declara que há que se fazer algumas adaptações da etnografia em seu sentido estrito, que para os antropólogos tem que cumprir alguns requisitos básicos, como por exemplo, uma longa permanência em campo. Segundo a autora acima citada, essa adaptação nos leva a concluir que, o que se faz em termos educacionais, na verdade, são estudos do tipo etnográfico, caracterizados especialmente pelo uso das técnicas que tradicionalmente são associadas à etnografia. Essas técnicas são as seguintes: observação participante, assim denominada porque o pesquisador age num grau de interação muito próxima do objeto estudado, afetando-o e sendo também afetado por ele; entrevistas, que têm por objetivo aprofundar e esclarecer questões nas situações observadas; e análise documental, que deve contextualizar o fenômeno, além de completar informações coletadas através de outras fontes.

No caso de minha pesquisa especificamente, ao estudar a terceirização do ensino de línguas dentro das escolas formais, esses procedimentos de fato foram utilizados, através da observação e descrição das aulas terceirizadas na forma presencial da pesquisadora; também entrevistas formais e informais foram realizadas com professores, com a diretora da escola terceirizada e com a coordenadora do instituto de idiomas. Além disso, foram realizadas também algumas análises documentais, utilizando material de propaganda disposta na mídia eletrônica.

Outra característica muito importante que permeia esses procedimentos etnográficos de modo constante é a interação entre o pesquisador e o objeto pesquisado (GEERTZ, 1987; FONSECA, 1998; ANDRÉ, 2003). André chega a declarar que "o pesquisador é o instrumento principal na coleta e análise dos dados” (p. 28). O pesquisador diferencia-se dos demais instrumentos de pesquisa por seu caráter pessoal, pois sendo um instrumento humano, responde de forma ativa e muitas vezes transformadora às circunstâncias que cercam a pesquisa, podendo muitas vezes modificar técnicas, rever questões que orientam a mesma, ou até rever a metodologia empregada durante todo o processo de investigação.

Sobre a importância do olhar do pesquisador na pesquisa etnográfica, Fonseca (1998) declara ainda que a subjetividade do mesmo é assumida como um componente essencial para a análise. Por envolver em geral, um número pequeno de informantes e por insistir na 
importância do contato pessoal do pesquisador com seu objeto de estudo, o método etnográfico propicia a subjetividade, porém os sentimentos e emoções que são a matéria prima dessa subjetividade, não são os da psicologia individual, ressaltando-se que os conceitos teóricos devem sempre se constituir em um embasamento forte para o pesquisador, pois se tornam ferramentas que o ajudam na interpretação dos dados da pesquisa. No entanto, sempre há limites para as posições metodológicas. Estar aberto às novidades que se apresentam ao longo da pesquisa é sempre útil. O pesquisador não deve levar seus preconceitos ao campo de pesquisa, mantendo-se sempre disposto a quebrar modelos e paradigmas anteriores (FONSECA, 1998).

Descrevemos até aqui, as características de cunho etnográfico que permearam esta pesquisa, dando uma visão geral desta metodologia. Passamos então a justificar a abordagem qualitativa também subjacente à metodologia escolhida para a pesquisa em questão.

Segundo André (2003), o termo "pesquisa qualitativa" tem sido empregado de forma equivocada e extremista, para designar a abordagem de qualquer estudo que não envolva números, ou seja, quantidade, criando uma dicotomia irregular que não expressa a real significação da mesma. Os termos qualitativo e quantitativo estariam ligados muito mais ao uso e à análise dos dados coletados, do que ao tipo de dados utilizados na pesquisa e análise. Assim sendo, pode-se utilizar números, quantidade, para se fazer uma análise não positivista, desde que esses números sejam analisados sob uma perspectiva de referência subjetiva, marcada pela posição teórica do pesquisador, de seus valores e de sua visão de mundo. Ao se reconhecer essas marcas da subjetividade na pesquisa, ainda que os dados sejam numéricos, distancia-se de uma postura positivista, que reconhece apenas os dados quantitativos como essenciais para a conceituação e posterior generalização, característica do método quantitativo.

Historicamente, a abordagem qualitativa de pesquisa tem suas raízes no final do século XIX, quando os cientistas começaram a questionar se os métodos de investigação científica empregados nas ciências físicas e naturais, fundamentados numa perspectiva positivista de conhecimento, poderia ser também empregado com a mesma eficácia para os estudos das ciências chamadas humanas, que estudavam os fenômenos humanos e sociais.

Ainda de acordo com André, estudiosos como Dilthey e Weber, contribuíram de forma significativa para a configuração da perspectiva qualitativa de pesquisa nas ciências humanas 
e sociais, deslocando o foco, ou o objetivo da pesquisa, da explicação da causa de um fato, para o entendimento deste fato em particular. Entram, portanto, em questão, a abordagem metodológica da hermenêutica, que se preocupa com a interpretação dos significados contidos num fato, levando em conta todas as interrelações deste fato, entre si e em seu contexto. Outros estudiosos também se juntaram a essas ideias, e ao final da década de 1980, debates entre o quantitativo e o qualitativo se prolongaram, uns defendendo a corrente idealistasubjetivista que valorizava a maneira própria de entendimento da realidade pelo indivíduo, enquanto que os outros, em oposição, mantinham uma visão empiricista da ciência, de mensuração, de constatação, de neutralidade do pesquisador para uma posterior generalização.

Para a experiência de análise de um fenômeno que ocorre em um espaço escolar, pretendida por este trabalho, as concepções acima descritas serão norteadoras da pesquisa, ressaltando que a visão de que a captação de dados também já é uma interpretação onde as concepções do olhar do pesquisador sobre o objeto pesquisado têm relevância sobre as representações que serão criadas a partir de suas conclusões.

$\mathrm{Na}$ pesquisa qualitativa, com essas bases etnográficas, há a possibilidade de se desenvolver as interpretações, não separando o pesquisador de suas emoções, dos seus próprios valores, intenções e de sua própria história. Portanto, não está previsto que as informações coletadas em entrevistas, observações e análises, se tornem estatísticas para quantificação. As interpretações, avaliações e análises das observações e relatos dos sujeitos da pesquisa, dependerão do olhar da pesquisadora e dos próprios sujeitos e de sua constituição, num contexto bastante particular.

Acredito que esta pesquisa poderá trazer contribuições acadêmicas na reflexão sobre o assunto, bem como poderá ser utilizada em comparações com outras pesquisas e interpretações construídas por outros pesquisadores em contextos parecidos.

Explicito ainda que, nesta pesquisa, dado o objeto de estudo ser a compatibilidade do ensino de língua estrangeira terceirizado na estrutura escolar, o enfoque se concentra muito mais no contexto, no entorno, na prática em si, do que nos sujeitos que dela participam, pois o foco estará muito mais no enredo do que na agência dos atores, embora esta não possa ser isolada do enredo em questão e a busca indagará sobre isso.

\subsection{Instrumentos de pesquisa}


Com base no que já foi colocado a respeito da escolha da metodologia para a realização desta dissertação, a saber, uma pesquisa qualitativa interpretativa de cunho etnográfico, reafirma-se que as análises serão feitas sempre a partir de interpretações, e dependerão do olhar da pesquisadora e do pesquisado, bem como de toda a contingência do objeto observado em seu contexto único e particular.

Um dos instrumentos de pesquisa que fornecerá uma fonte de dados para análise são as descrições das observações das aulas de língua estrangeira terceirizadas, feitas pela pesquisadora. Nestas observações foi levado em conta todo o contexto da realização da aula, desde o espaço físico, materiais didáticos utilizados, atitudes dos alunos e dos professores, até a proposta de ensino propriamente dita.

Além disso, entrevistas com professores, coordenadores e diretores que participam da terceirização, bem como questionários escritos respondidos por alunos e pais de alunos das escolas terceirizadas, fazem parte do arcabouço de dados que serviram para análise. A maioria das entrevistas foi realizada de maneira formal, oralmente, gravadas e transcritas; no entanto, entrevistas informais, como algumas "conversas" entre a pesquisadora e os professores, e entre a pesquisadora e alunos, também foram consideradas como diário da pesquisadora, portanto, fonte de dados para análise.

Instrumentos documentais, como o planejamento das aulas terceirizadas utilizado pelos professores do instituto de idiomas, embora estivessem previstos em cronograma para fazerem parte do arcabouço de dados, não puderam ser analisados em relação aos objetivos educacionais do ensino de língua estrangeira propostos pela comunidade escolar, pois houve recusa dessa possibilidade por parte do instituto de idiomas, fato que certamente foi relevante como dado para análise.

Além disso, visto o objeto de pesquisa ser o estudo do fenômeno ligado à terceirização de um ensino dentro de um estabelecimento de educação formal - o ensino de línguas estrangeiras - considerei que as propagandas poderiam ser também uma fonte de dados documentais, trazendo uma visão dos dois lados da moeda, pois mostrariam as propostas dos institutos de idiomas terceirizados, bem como os interesses ou necessidades das escolas formais no que se refere ao ensino da língua estrangeira, criando assim um panorama ampliado de todo o contexto da terceirização desse ensino na escola regular. Portanto, as propagandas dos institutos de idiomas que oferecem os referidos serviços de terceirização de ensino de línguas estrangeiras no formato intracurricular, as quais estão disponibilizadas em sites institucionais na internet, foram também utilizadas. 


\subsection{Comunidade investigada}

Várias foram as comunidades escolares com as quais entrei em contato para a realização da pesquisa. A princípio, procurei via internet, através de sites institucionais das escolas de idiomas que ofereciam o serviço de terceirização do ensino de Inglês, os nomes de algumas escolas que faziam essa parceria no formato intracurricular, ou seja, onde a escola de idiomas atuava dentro do currículo básico da escola de educação formal. Encontrei várias opções, porque os sites dispunham essas informações, na maioria das vezes, como forma de propaganda de seus serviços de terceirização.

No entanto, ao contatar as escolas terceirizadas, deparei com várias dificuldades, como por exemplo, a falta do poder de decisão para que a permissão do encaminhamento da pesquisa acontecesse naquela instituição. Invariavelmente, todas as instituições escolares reportaram-se ao instituto de idiomas solicitando que a autorização final a respeito da observação das aulas, entrevistas e demais conversas, fosse deles. Esse fato certamente merece uma interpretação mais detalhada, que será realizada junto das análises da pesquisa, posteriormente.

A escola onde atuei como pesquisadora é uma instituição com vários anos de experiência como instituição educacional particular, atuando em uma região de classe média alta, na cidade de São Paulo, nos níveis de educação infantil - maternal, jardim e pré-escola e também no ensino fundamental I e II $-1^{\circ}$ ao $5^{\circ}$ anos (antigo pré e $1^{\mathrm{a}}$ a $4^{\mathrm{a}}$ séries), e também do $6^{\circ}$ ao $9^{\circ}$ anos (antiga $5^{\mathrm{a}}$ a $8^{\mathrm{a}}$ séries).

Essa escola possui uma característica diferenciada, pois trabalha com regime de horário integral para grande parte de seu alunado. Na parte da manhã, as matérias do currículo comum são oferecidas a todos os níveis, com intervalo para lanche matutino; no meio do dia, encerra-se o período de estudo das matérias do currículo comum, havendo um período para almoço, feito num refeitório próprio da escola, refeições estas, produzidas ali mesmo, por equipe especializada. No período da tarde, atividades diversificadas como natação, esportes, ballet, judô, iniciação musical, teatro, artes específicas, entre outras, são oferecidas aos alunos de período integral. No entanto, grande parte da clientela frequenta apenas o período da manhã, onde são ministradas as disciplinas do currículo comum de educação básica.

Vale ressaltar que, as aulas de inglês e espanhol, terceirizadas nesta instituição, são realizadas durante o período matutino, dentro das disciplinas de currículo comum. As aulas 
terceirizadas são ministradas no próprio espaço da escola, nas classes normais de cada turma, que após o nível inicial básico, normalmente a partir do ensino fundamental II, são divididas em níveis de conhecimento linguístico. Essas aulas são ministradas pelos professores do instituto de idiomas que vêm até a escola, seguindo a grade curricular normal, ou seja, duas aulas semanais de 50 minutos.

Nesta pesquisa, a escola onde acontece a terceirização será denominada de I.S., enquanto que o instituto de idiomas receberá o pseudônimo de English Center.

As tabelas seguintes apresentam os participantes da pesquisa, elencados respectivamente em entrevistas formais - tabela 1 - e informais - tabela 2; além disso, apresentam também o formato, a etapa de realização da entrevista, bem como sua importância para o contexto geral da pesquisa.

Tabela 1 - Entrevistas Informais

\begin{tabular}{|c|c|c|c|c|}
\hline $\begin{array}{ll}\text { Sujeito } & \text { de } \\
\text { pesquisa } & \end{array}$ & $\begin{array}{l}\text { Contexto } \\
\text { situação }\end{array}$ & Formato & $\begin{array}{ll}\text { Etapa } & \text { de } \\
\text { realização } & \end{array}$ & Importância \\
\hline $\begin{array}{l}\text { a)Professores } \\
\text { teceirizados. } \\
\text { (não } \\
\text { denominados na } \\
\text { pesquisa) }\end{array}$ & $\begin{array}{l}\text { Horários dos } \\
\text { intervalos das } \\
\text { aulas, na sala } \\
\text { dos professores } \\
\text { da escola I.S. }\end{array}$ & $\begin{array}{l}\text { Bate-papo } \\
\text { informal entre } \\
\text { os professores e } \\
\text { a pesquisadora. }\end{array}$ & $\begin{array}{l}\text { Dias } \\
\text { estabelecidos } \\
\text { para observação } \\
\text { de aulas } \\
\text { terceirizadas na } \\
\text { escola I.S. }\end{array}$ & $\begin{array}{l}\text { Reação } \\
\text { espontânea, sem } \\
\text { respostas } \\
\text { dirigidas ou } \\
\text { previamente } \\
\text { preparadas, sem } \\
\text { a interferência } \\
\text { hierárquica da } \\
\text { direção ou da } \\
\text { coordenação do } \\
\text { English Center. }\end{array}$ \\
\hline
\end{tabular}




\begin{tabular}{|l|l|l|l|l|}
\hline b)alunos & Durante as & Bate-papo & Dias & Reação \\
terceirizados. & observações das & informal entre & estabelecidos & espontânea, sem \\
(não & aulas & aluno(s) & e & para observação \\
denominados na & terceirizadas ou & pesquisadora. & de aulas. & presença da do \\
pesquisa) & em encontros & & & \\
professor. & \\
& casuais nos & & & \\
\hline
\end{tabular}

Tabela 2 - Entrevistas formais

\begin{tabular}{|c|c|c|c|c|}
\hline $\begin{array}{l}\text { Sujeito } \\
\text { pesquisa }\end{array}$ & $\begin{array}{l}\text { Contexto / } \\
\text { situação }\end{array}$ & Formato & $\begin{array}{ll}\text { Etapa } & \text { de } \\
\text { realização } & \end{array}$ & Importância \\
\hline $\begin{array}{l}\text { a)Diretora da } \\
\text { escola } \\
\text { terceirizada } \\
\text { (nome fictício: } \\
\text { Prof. }{ }^{\text {a Rosa) }}\end{array}$ & $\begin{array}{lr}\text { Data marcada } \\
\text { pela própria } \\
\text { diretora } & \text { após a } \\
\text { leitura } & \text { do } \\
\text { projeto } & \text { de } \\
\text { pesquisa } & \text { em } \\
\text { questão, } & \text { na } \\
\text { escola I.S. } & \end{array}$ & $\begin{array}{l}\text { Conversa entre a } \\
\text { pesquisadora e a } \\
\text { diretora da I.S., } \\
\text { dirigida por } \\
\text { esta, com } \\
\text { questionamentos } \\
\text { da pesquisadora. }\end{array}$ & $\begin{array}{l}\text { Etapa inicial da } \\
\text { pesquisa, após } \\
\text { contatos virtuais } \\
\text { e telefônicos } \\
\text { antes das } \\
\text { observações de } \\
\text { aulas. }\end{array}$ & $\begin{array}{l}\text { Conhecimento } \\
\text { das } \\
\text { características } \\
\text { gerais da } \\
\text { comunidade } \\
\text { investigada, } \\
\text { bem como de } \\
\text { características } \\
\text { físicas } \\
\text { pedagógicas da } \\
\text { mesma. }\end{array}$ \\
\hline $\begin{array}{l}\text { b)Professores } \\
\text { que participam } \\
\text { da terceirização, }\end{array}$ & $\begin{array}{l}\text { Data marcada } \\
\text { previamente } \\
\text { pela }\end{array}$ & $\begin{array}{lr}\text { Entrevista } & \text { oral, } \\
\text { gravada } & \mathrm{e} \\
\text { transcrita, } & \text { com }\end{array}$ & $\begin{array}{l}\text { Algumas } \\
\text { semanas após as } \\
\text { observações de }\end{array}$ & $\begin{array}{l}\text { Visões } \\
\text { educacionais } \\
\text { pessoais, }\end{array}$ \\
\hline
\end{tabular}




\begin{tabular}{|c|c|c|c|c|}
\hline $\begin{array}{l}\text { escolhidos pela } \\
\text { coordenação do } \\
\text { English Center } \\
\text { (denominados } \\
\text { P1 e P2). }\end{array}$ & $\begin{array}{l}\text { coordenadora } \\
\text { do English } \\
\text { Center, na } \\
\text { escola I.S. }\end{array}$ & $\begin{array}{l}\text { questões } \\
\text { elaboradas pela } \\
\text { pesquisadora } \\
\text { (apêndice....); } \\
\text { duração de } 40 \text { a } \\
50 \text { minutos. }\end{array}$ & $\begin{array}{l}\text { aulas já terem } \\
\text { sido realizadas. }\end{array}$ & $\begin{array}{l}\text { embora } \\
\text { possivelmente } \\
\text { delimitadas pelo } \\
\text { treinamento } \\
\text { metodológico } \\
\text { aplicado pelo } \\
\text { English Center, } \\
\text { ou ainda pela } \\
\text { interferência } \\
\text { provável da } \\
\text { coordenadora. }\end{array}$ \\
\hline $\begin{array}{l}\text { c)Coordenadora } \\
\text { do English } \\
\text { Center } \\
\text { (denominada } \\
\text { C1) }\end{array}$ & $\begin{array}{l}\text { Solicitação de } \\
\text { encontro } \\
\text { pessoal não } \\
\text { possível. }\end{array}$ & $\begin{array}{l}\text { Questionário } \\
\text { escrito } \\
\text { elaborado pela } \\
\text { pesquisadora } \\
\text { (apêndice ...), } \\
\text { enviado e } \\
\text { respondido via } \\
\text { e-mail, pela } \\
\text { coordenadora do } \\
\text { English Center. }\end{array}$ & $\begin{array}{l}\text { Algumas } \\
\text { semanas após o } \\
\text { término das } \\
\text { observações de } \\
\text { aulas. }\end{array}$ & $\begin{array}{l}\text { Conhecimento } \\
\text { das } \\
\text { características } \\
\text { gerais do } \\
\text { programa de } \\
\text { terceirização } \\
\text { implantado pelo } \\
\text { English Center, } \\
\text { bem como os } \\
\text { objetivos desta } \\
\text { prática. }\end{array}$ \\
\hline
\end{tabular}

O diário da pesquisadora contendo todas as informações e conversas realizadas durante as observações de aula está disponível em registro escrito, no apêndice (p. 142).

Embora tenha sido prevista uma entrevista formal por escrito com pais e alunos terceirizados, em cronograma inicial da pesquisa, esta não pode ser realizada devido a ausência da autorização por parte da direção da escola I.S. Esse fato será tratado posteriormente no item 2.5 deste trabalho.

\subsection{Em busca da harmonia dos dados: Prelúdio e Interlúdio.}


Ao longo de uma pesquisa, não raro, nos deparamos com alguns obstáculos e revezes muitas vezes não previstos quando da intenção do planejamento e organização. Assim ocorreu com esta pesquisa em relação a pelo menos duas fases programadas para a obtenção de dados, a saber, numa fase inicial, as várias tentativas de contato com escolas terceirizadas que permitissem a entrada de um pesquisador em seu cotidiano escolar e, numa fase posterior, a obtenção de dados específicos através de entrevistas com pais e alunos terceirizados, bem como a tentativa da obtenção de um plano descritivo dos objetivos pedagógicos das aulas terceirizadas do instituto de idiomas.

Embora estas fases estivessem previstas numa pré-organização e no cronograma da pesquisa, as previsões não aconteceram como o esperado, causando, num primeiro impacto, uma certa frustração por um lado, mas por outro, uma possibilidade de interpretação, pois os fatos tornaram-se objeto de análise e fonte de dados.

Chamarei a primeira fase - as tentativas de entrada em campo e o contato com as escolas terceirizadas para a efetuação da pesquisa - de prelúdio; e de interlúdio, a tentativa da obtenção de dados através de entrevistas com pais e alunos terceirizados, bem como a obtenção do plano de objetivos pedagógicos do instituto de idiomas.

Registro, primeiramente, as tentativas de contato com as escolas terceirizadas, o prelúdio. Considero esta fase da pesquisa uma das mais difíceis de se realizar, devido às dificuldades de se conseguir contatos e autorizações em ambientes tão dinâmicos como são as escolas. Creio ser importante descrever esses acontecimentos, interpretando essa dificuldade já como uma fonte de análise para a pesquisa.

Em um dos sites de uma famosa escola de idiomas, que neste trabalho recebe o pseudônimo de English Center, conforme já mencionado, encontramos uma boa quantidade de escolas com esse perfil, a maioria conhecida e renomadamente atuante na área de ensino informal de Inglês e outros idiomas.

Nosso primeiro contato com as escolas elencadas foi feito por e-mail, através dos endereços eletrônicos disponíveis no referido site da escola de idiomas English Center. Isso aconteceu em final de agosto de 2007 e aguardamos resposta de quatro escolas, escolhidas a princípio, por facilidade na localização. Depois de algum tempo, uma escola respondeu à solicitação, dispondo um telefone de contato para marcar um encontro com a coordenação pedagógica. 
Na data marcada, fui muito bem recebida pela coordenadora pedagógica que mostrouse interessada em colaborar com a pesquisa, ressaltando que qualquer acerto final, deveria ter a autorização da escola de idiomas English Center. No entanto, ao conversarmos sobre o tipo de pesquisa a ser realizada, percebemos que havia um mal-entendido em relação ao tipo de parceria que era o objeto da mesma, a saber, a terceirização no formato intracurricular, onde o instituto de idiomas passa a realizar todas as ações pertinentes ao ensino de língua, dentro da grade curricular do curso, e infelizmente naquela escola, esse processo atuava em nível de convênio e no formato extracurricular, onde o instituto de idiomas oferece as aulas de língua, fora da grade curricular do curso, normalmente em horário oposto ao das aulas e normalmente utilizando as instalações da escola parceira; portanto não serviam para minha observação, que tem como foco o meio escolar.

A partir dessa impossibilidade tentei novamente contato com as demais escolas, duas das quais me responderam com um contato telefônico da coordenação pedagógica. Chamarei essas escolas respectivamente, pelo pseudônimo de colégio I.P. e colégio I.S.

Com a escola I.P. tive contatos telefônicos durante mais ou menos três semanas tentando marcar um encontro com a coordenação pedagógica, que na época estava muito envolvida com provas de bolsa para o Ensino Médio (tipo cursinho) para o ano seguinte.

Após três semanas, consegui contato com a coordenadora do Ensino Médio, que tinha quatro turmas com o Inglês terceirizado no formato intracurricular pela escola English Center, assegurando que eu poderia fazer a pesquisa assim que a gerência do English Center desse a autorização para a mesma.

Infelizmente, depois de várias ligações para contatos com a coordenação tanto da escola I.P., quanto da English Center, essa autorização não veio. Foi-me enviado um e-mail contando da impossibilidade da pesquisa devido ao curto espaço de tempo que restava até o final do ano.

Concomitantemente a esses acontecimentos, mantive contatos telefônicos e por e-mail com a outra escola contactada, a escola I.S. Houve uma abertura bastante grande por parte da escola I.S., com a qual passei a manter contatos com a própria diretora, que, visando preservar as identidades na investigação, chamarei de Rosa. Esta sugeriu-me aguardar contato posterior, pois a escola estava muito envolvida com uma atividade especial na instituição.

Como outros contatos não estavam sendo bem sucedidos, depois do tempo solicitado pela diretora, após a atividade especial, voltei a fazer o pedido de solicitação de observação das aulas de Inglês, ao que ela me respondeu que enviasse um resumo de minha pesquisa para 
que se inteirasse do assunto, e assim me receberia para uma entrevista pessoal. Disse-me também que deveria fazer o mesmo, para a gerente da escola English Center, enviando também uma cópia a ela, da qual dependeria a autorização para a realização das observações das aulas.

Depois de vários contatos por e-mail e telefone, consegui a primeira entrevista com a Diretora da escola, Prof. ${ }^{\text {a }}$ Rosa, que me recebeu para que eu detalhasse aspectos da pesquisa e também para que entregasse em mãos a autorização da universidade.

Enquanto eu detalhava aspectos essenciais da pesquisa resumidamente, ela escrevia no próprio papel do projeto, dizendo que era para não esquecer nada, pois haveria um encontro com a supervisora do English Center, para tratarem do assunto.

Contei em poucas palavras sobre os pressupostos da pesquisa, a percepção da ineficácia do ensino de língua estrangeira na escola formal e o interesse em pesquisar uma das formas utilizadas pelas escolas para tentar resolver o problema: a terceirização ou parceria com os institutos de idioma.

A Prof. ${ }^{a}$ Rosa contou-me sobre a especificidade de sua escola, que é o trabalho em período integral, como opção e não apenas como necessidade. Contou-me também, a respeito da visão multidisciplinar que me pareceu a base da filosofia da escola. Relatou-me que para o I.S. é tão importante aprender matemática, quanto ter habilidade para atuar em uma dramatização, e o mesmo valor que é dado para uma produção artística também é dado para uma produção acadêmica. Num primeiro momento, essa preocupação com a interdisciplinaridade destacada pela diretora remeteu-me ao fato explicado por Usher e Edwards (1994) de que as escolas, sob o impacto das mudanças epistemológicas geradas pela pós-modernidade, passam a buscar na interdisciplinaridade, alternativas para o ato de ensinar e aprender. Assim, deixam de buscar respostas prontas e receitas, pois a partir dessa perspectiva pós-moderna, a busca por um discurso alternativo, com respostas locais e contextualizadas passa a fazer mais sentido.

Nessa entrevista informal, a Prof. ${ }^{a}$ Rosa destacou também, que nada na escola é terceirizado - desde o ensino até a alimentação e limpeza da escola - todos os profissionais são especificamente preparados para "entrarem" na visão de educação que a escola tem, com exceção do ensino de inglês. Interessante notar a ênfase dada na unidade de visão pedagógica, de falas e procedimentos que é buscado pela escola, preparando cada funcionário como um educador em potencial, para que todos falem a "mesma língua", excetuando-se literalmente, o ensino de língua estrangeira. Através desse fato, contruindo uma primeira impressão sobre a 


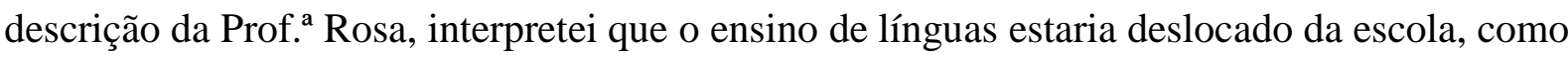
se ele não fizesse parte da constituição educacional comum a todas as outras disciplinas escolares. Uma impressão a ser investigada, logicamente. A referida descrição remeteu-me a uma visão do ensino de línguas concentrada em técnicas e metodologias, pois a língua estrangeira em si seria vista como uma ferramenta, como um bem de consumo e não como sendo parte da constituição do sujeito e, portanto, passível de objetivos formativos. Corroborando esse sentido, Giroux (2004) destaca ser a língua um espaço de negociação dos elementos mais fundamentais das identidades dos sujeitos, das suas relações com os outros e com o resto do mundo, tratando-se de uma prática moral e política relacionada com sua atuação crítica dentro de seu contexto social.

$\mathrm{Na}$ continuidade da conversa, a diretora relatou que há cerca de três anos, mais ou menos, preocupados com o aparente fracasso do ensino do Inglês, com a qualidade das aulas e principalmente com a diferença de níveis que os alunos de uma mesma turma tinham, a escola optou por terceirizar esse ensino junto a uma instituição que fosse renomada e experiente dentro do mercado. Disse: "não conseguíamos fazer bem, com qualidade, e queríamos alguém que pudesse fazê-lo". Destacamos nessa fala três aspectos bastante relevantes:

a) a escolha pela terceirização junto a uma instituição renomada e experiente dentro do mercado do ensino de línguas, denota uma das principais características desse fenômeno empresarial. Amato Neto (1995) explica que esse fenômeno caracteriza-se pela necessidade de a empresa moderna focalizar seus esforços nas atividades que realmente possam se traduzir em vantagens competitivas. Ou seja, no mercado educacional, sob essas perspectivas empresariais competitivas, o ensino de línguas numa escola de educação formal não conseguiria comparar-se ao ensino de línguas num instituto de idiomas;

b) a busca da qualidade sendo destacada como uma das razões para a procura da terceirização, sendo que a melhora da qualidade e dos resultados além da redução de custos, são objetivos empresariais conseguidos através da focalização, que é a dispensa de atividades que não sejam atividades-fim, sendo estes delegados para contratados especializados naquele serviço (AMATO NETO, 1995).

c) uma certa impotência, uma sensação de fracasso, nos dizeres "não conseguíamos fazer bem" demonstrando a adequação ao discurso generalizado de que não se aprende língua estrangeira na escola de educação formal (OLIVEIRA, 2005; MARTINEZ, 2007). 
Vale citar que a preocupação com a qualidade, preocupação proeminente na fala da diretora, no mundo escolar assim como no mundo dos negócios, não é nova, possui uma história. O significado de qualidade na educação já mudou da aplicação de bons recursos humanos, materiais dos sistemas escolares, e sua relação com custos (mais recursos, mais qualidade), para depois focar-se na eficácia do processo: conseguir resultados máximos com o mínimo de custos, e daí para hoje, para a avaliação dos resultados obtidos pelos estudantes, qualquer que seja a forma de medi-los (GENTILI, 1994).

$\mathrm{Na}$ verdade, essa preocupação deriva-se da necessidade de ajustar a educação ao mercado. Citando Gentili (op. cit.), percebe-se então, que a disseminação do princípio do mercado fará com que no final do seu trabalho como educador, a competitividade desse produto é que determinará o seu valor.

Não há dúvida que deve haver pontos de intersecção e cooperação entre a educação e o mercado. Contudo, parece ser muito diferente a pretensão política da nova retórica da qualidade no campo educacional, que subordina a educação ao mercado, convertendo-a em mais um instrumento da complexa maquinaria de dualização e polarização social, que são características do projeto neoconservador.

Em grande parte da fala da Prof. ${ }^{\text {a }}$ Rosa somos levados a ver como as instituições Mercado e Escola, não só no campo discursivo, mas também no pragmático, se relacionam, se intersectam, se interpenetram.

Ao continuar seu relato, contou-me também que as turmas são divididas em níveis, a seu ver uma das melhores coisas que a parceria trouxe; relatou também que os professores são treinados pela instituição todo o tempo, e que dos professores anteriores, apenas um foi mantido, porque optou por fazer um treinamento na instituição English Center. Ressaltou que sua grande preocupação é justamente o fato de que um maior número de professores muitas vezes não consegue entrar no espírito da escola, por não conviverem com a filosofia diariamente. Referiu-se também ao fato de que os institutos de idiomas, na hora da seleção de professores, privilegiam o aspecto linguístico do candidato, ou seja, este tem que ser fluente na língua, e não há ênfase na sua formação como educador. Ela sugeriu que muitos professores são proficientes, mas não têm formação pedagógica, não são educadores. Diz ser essa sua grande preocupação em relação à parceria, por isso mostrou-se interessada nos resultados de minha pesquisa. Interessante notar nessa fala, uma quase contradição na preocupação da diretora com o privilégio dado ao aspecto línguístico do ensino de línguas estrangeiras, sendo que em sua fala anterior, a preocupação com a qualidade do ensino de 
língua remetia-nos justamente a esse aspecto, embora interpretemos isso do não-dito. Sua preocupação com os aspectos educacionais do ensino de língua é também notada, referindo-se à provável falta de formação pedagógica dos professores, apesar de sua proficiência.

No restante da conversa, relatou-me que em recente pesquisa de opinião sobre a escola feita com os pais, para sua surpresa, o ensino de inglês ainda aparece como uma preocupação, fato que a surpreendeu, pois achava que a parceria diminuiria essa expectativa dos pais. Ressaltou, porém, que a seu ver, os alunos garantidamente estão possuindo maior desenvoltura depois da parceria, pois em contato com atividades desenvolvidas pela própria instituição de idiomas, English Center, eles se comparam aos demais alunos que frequentam os cursos normais de idiomas e seu nível de aprendizagem é igual ou melhor que o dos outros. Notamos aqui, uma certa postura avaliativa do processo de terceirização, tentando verificar se houve melhora no ensino de línguas terceirizado. A surpresa da diretora ao notar a preocupação dos pais demonstra uma certa decepção na tentativa de buscar soluções para o "problema" do ensino de língua estrangeira, conforme já apontado em pesquisa de Uechi (2006), através da terceirização pelo instituto de idiomas. Há uma evidente busca da escola em se completar no outro, o instituto de idiomas, que será capaz de completar a presente falta, um ensino eficaz da língua. Grigolleto (2004), comentando sobre a constituição do sujeitoprofessor e do sujeito-aluno frente a comparações, denota um sujeito desejante através da presença marcante do discurso da falta, descrita em muitas pesquisas como a falta de aptidão, falta de competência, falta de conhecimento, falta de treino. Assim, retomando a fala da diretora, observa-se que a auto-avaliação dos seus próprios alunos é feita através da comparação com o outro, o aluno do instituto de idiomas, interpretando que lá o aluno é mais completo e mais conhecedor, transparecendo a idéia de "falta" que caracteriza o ensino de línguas na escola regular. Em contrapartida, na avaliação dos pais, a qual surpreendeu a diretora, não há essa certeza de melhora e de eficácia. No entanto, a mesma preocupação de busca pela eficácia é percebida neles. Em pesquisa sobre o discurso de pais e alunos sobre o ensino de línguas, Oliveira (2005) destaca que a posição dos sujeitos pais, como responsáveis pela educação e consequente sucesso dos filhos, obriga-os a defenderem um ensino de língua que permita que seus filhos tenham mais chances de realização na sociedade globalizada. Pensa-se, portanto, na valoração dos objetivos linguísticos e técnicos da língua, numa visão ideológica neoliberal, onde a educação é vista como preparação para o mercado de trabalho. 
Terminamos nosso encontro, com a promessa de que ela me ligaria para dar a certeza sobre datas e horários para minha observação, após a autorização da gerência da escola English Center.

Após esse encontro, em alguns dias recebi o contato da gerente da escola English Center de determinada região de São Paulo, que autorizou a realização de minha pesquisa na escola I.S., determinando todos os pormenores para a mesma. Ela marcou dias e horários, níveis e professores onde eu faria a observação.

Vale destacar que a entrada em campo para a pesquisa, foi delineada pela escola de idiomas e não pela diretora e proprietária da escola. Todas as permissões foram concedidas pela escola de idiomas English Center, para a qual parecem ter sido delegadas todas as decisões em relação ao ensino de língua na escola e, esta definiu as questões relacionadas à minha estada na escola terceirizada. Segundo Focault (1987), o poder deve ser analisado como algo que circula, ou como algo que ocorre em cadeia; nunca está totalmente localizado aqui ou ali, mas funciona e se espalha em rede. Dessa forma, o exercício de poder esperado da I.S. como proprietária em termos de posse do capital, contratante do serviço do English Center, e responsável pela autorização para pesquisa por si só, considerando-se as definições das prerrogativas da pesquisa, não aconteceu. Este foi transferido para o instituto de idiomas, que no caso, não tinha o poder do capital, mas o poder do saber, no caso, o conhecimento da língua estrangeira e o poder da promessa do sucesso. Essa dominação é descrita por Foucault (1987), da seguinte forma:

Por dominação eu não entendo o fato de uma dominação global de um sobre o outro, ou de um grupo sobre o outro, mas as múltiplas formas de dominação que podem se exercer na sociedade. Portanto, não o rei em sua posição central, mas os súditos em suas relações recíprocas: não a soberania em seu edifício único, mas as múltiplas sujeições que existem e funcionam no interior do corpo social (p. 181).

Já em outra fase da pesquisa bem mais adiantada, metaforicamente denominada de interlúdio, conforme previsto no cronograma e na organização das obtenções de dados, tínhamos como previsão, a realização de entrevistas formais com os pais e com os alunos terceirizados. Essa entrevista seria no formato escrito para viabilizar de forma mais eficiente o contato com os pais, pois encontrá-los pessoalmente seria bastante difícil. Era nosso objetivo interpretar as diferentes visões de todos os envolvidos no processo de terceirização. Assim, solicitamos à coordenadora pedagógica do I.S., que era a pessoa com a qual mantínhamos contato dentro da escola, a permissão para fazermos as entrevistas. Enviamos o modelo da 
entrevista, a qual está disponível nos anexos deste trabalho, que dispunha de perguntas simples sobre aspectos gerais da aprendizagem de língua estrangeira na escola, antes e depois da terceirização, pontuando a opinião tanto dos pais quanto dos alunos sobre sua visão dos resultados dessa prática. Ela solicitou então, um tempo para conversar a respeito com a diretora, Prof. ${ }^{a}$ Rosa, que nos daria essa permissão, marcando a data adequada para isso.

Passadas algumas semanas sem haver uma resposta, procuramos novamente a coordenadora pedagógica do I.S. buscando a necessária permissão para as entrevistas, no entanto, ela solicitou mais algum tempo, pois segundo ela, a diretora da escola não tomaria essa decisão sozinha; havia a necessidade de reunir uma chamada comissão pedagógica para que a permissão fosse concedida. Enviamos novamente o modelo das entrevistas e nos dispusemos a conversar sobre ajustes nos questionamentos, caso fosse necessário, bem como a estar presente nessa reunião para explicarmos nossos objetivos de pesquisa.

Durante alguns meses foram realizados muitos contatos via e-mail repetindo a solicitação das entrevistas. Por variadas vezes, obtivemos respostas evasivas para que aguardássemos a reunião do conselho. Não havendo decisão, nem afirmativa nem negativa, as respostas acabaram por silenciar-se e entendemos que nossa entrevista não poderia ser realizada, visto haver um prazo para a pesquisa, tornando-se inviável que esperássemos mais por essa permissão.

Ao analisarmos esse fato, uma negativa de contato com os pais e alunos terceirizados, embora não explicitamente, interpretamos que numa relação comercial, entre prestador de serviço e sua clientela, é de se esperar que haja certa resistência de que terceiros interfiram num suposto processo de avaliação, sugerido pelas entrevistas da pesquisa. As relações mercadológicas advindas dessas parcerias de escolas formais com instituições do mercado de ensino de língua estrangeira, os institutos de idiomas, tornaram pais e alunos em clientes, a escola, na figura do professor especificamente, em prestador de serviços, e o conhecimento, no caso a língua estrangeira, em mercadoria (GENTILI, 1996). Um estudo mais aprofundado sobre as características do neoliberalismo e sua influência nos meios educacionais será feito posteriormente neste trabalho.

Sob um contexto neoliberal, em variadas esferas, segundo Bueno (2003), vive-se num momento de aumento vertiginoso das tendências capitalistas à mercantilização, transformando tudo, compulsivamente, em mercadoria. Nas suas palavras, 
Uma a uma, todas as esferas da vida humana - educação, saúde, cultura, esportes - vão sendo infectadas pelo vírus insidioso que reduz todas as relações e transações mercantis, ao reino do cálculo e do interesse individual... No domínio da educação o processo infeccioso salta aos olhos (op. cit. p.9).

Assim, interpretamos que a negativa à realização do contato com os pais e alunos terceirizados, num caráter avaliativo, foi vista como uma interferência dentro desse círculo mercadológico entre cliente e prestador de serviço, podendo sugerir uma possível ineficiência de gestão ou questionamento de qualidade, quando feita por terceiros, no caso a pesquisadora. Inferimos também, que muito provavelmente, essa decisão de não permitir as entrevistas com os pais e alunos terceirizados, também tenha tido a influência do instituto de idiomas English Center, posto que todas as decisões sobre as visitas da pesquisadora, escolha de aulas e professores a serem observados, foram feitas pelo instituto, como já descrito anteriormente.

Ainda fazendo parte dessa busca da harmonia metafórica, pela obtenção de dados, durante o interlúdio, como previsto em cronograma e organização da pesquisa, buscamos o instituto de idiomas English Center, para viabilizarmos a possibilidade de acesso a um material pedagógico que contivesse o planejamento educacional da escola terceirizada, onde aparecessem os objetivos de ensino. Nossa intenção era fazer uma análise desses documentos com a prática já constatada através das observações de aulas já realizadas até então, bem como compará-los com os documentos dos PCNs e OCEM em termos de objetivos, visto que, os professores que foram entrevistados, afirmarem que, estar de acordo com a linha desses documentos, era uma preocupação de seu planejamento (entrevistas no apêndice p. 142-152).

Ao procurarmos a coordenadora do instituo de idiomas English Center, a qual era nosso contato para todas as permissões de pesquisa de dados, ela nos disse que não havia a possibilidade de acesso a nenhum material de planejamento da instituição, visto tratar-se de um documento mantido em sigilo, com acesso permitido somente aos profissionais devidamente ligados à instituição.

Essa postura de não abertura a qualquer possibilidade de divisão ou amostra do material de produção do instituto de idiomas, evidencia uma postura bastante comum no mundo empresarial, onde certamente, regidos pela competição do mercado, as condições de produção de seus próprios bens comerciais, seriam obviamente vedados, a fim de garantir o "segredo" de qualidade dos seus produtos. Sendo o conhecimento da língua estrangeira um 
produto comercializado por esta instituição, o acesso a ele, na forma do planejamento, seria regulado apenas por relações comerciais de compra e venda, legitimados neste caso específico, pela terceirização do ensino. A possibilidade de troca ou mesmo de intercâmbio, numa relação onde os objetivos educacionais estivessem em evidência, posto tratar-se de uma investigação científica legitimada por uma universidade no pedido feito pela pesquisadora, foi subjugado pela proposição capitalista da competitividade nas relações comerciais.

Gómez (2001), ao comentar sobre a crescente e até mesmo já instituída política educativa neoliberal, destaca que a descentralização e a competitividade entre as instituições educativas são os primeiros passos para uma desregulação desse sistema, para a privatização das instituições ou seus serviços, bem como para a consideração e "o tratamento da educação como uma mercadoria a mais no cenário competitivo do livre mercado" (op. cit. p.138). Essa já é uma realidade, não só nas escolas particulares, como trata esta pesquisa, mas atualmente, já evidencia-se essa prática terceirizadora também nas instituições educacionais públicas, fato a ser especialmente analisado em capítulo posterior.

\subsection{Organização da Dissertação}

A primeira parte do trabalho até aqui desenvolvida teve um caráter introdutório para que o leitor se situasse em relação ao tema desenvolvido, a metodologia escolhida para a pesquisa e também em relação à perspectiva do meu locus de enunciação como pesquisadora. Foram apresentados também os instrumentos de pesquisa e a comunidade investigada.

A partir dessa introdução, o trabalho será desenvolvido em três capítulos, os quais descrevo a seguir:

Capítulo 1- As Teorias dos Novos Letramentos: esse capítulo pretende mostrar as bases teóricas nas quais se fundamentaram as análises feitas no decorrer de toda a pesquisa.

Há uma subdivisão em três itens, a saber:

1.1- $\quad$ O ensino de língua inglesa praticado nas últimas décadas, que pretende dar uma visão geral dos caminhos trilhados pelo ensino de língua estrangeira, através de variadas tentativas de mudanças metodológicas e adaptações à modernidade tecnológica;

1.2- O ensino de língua inglesa numa perspectiva educacional, que aponta para uma nova visão de ensino onde os objetivos educacionais se sobrepõem às técnicas e objetivos linguísticos até então tomados como prioridade no ensino de LI. Nesse item, entre outros 
aspectos serão revistas as propostas de documentos renovados da educação brasileira, como as OCEM (2006).

1.3- Subsídios teóricos para a proposta educacional de língua inglesa, que apresenta um panorama histórico das teorias dos Letramentos e dos Multiletramentos, discutindo sua aplicabilidade numa perspectiva educacional de ensino de língua na atual sociedade brasileira.

Capítulo 2- A Terceirização do Ensino de Idiomas: uma proposta educacional?

Esse capítulo destaca o fenômeno da terceirização discutindo sua implantação tida como uma possível solução para o "problema" do ensino de língua estrangeira nas escolas formais. Subdivide-se nos itens:

2.1- Contextualizando a Terceirização do ensino de língua inglesa, onde são apresentados os aspectos do Neoliberalismo como pano de fundo para toda a dinâmica de mercado envolvendo não apenas instituições econômicas, como também instituições outras, como a escola;

2.2- Pressupostos da terceirização, onde destaca-se a visão mercadológica como fundamento desta prática;

2.3- Os conflitos da terceirização, onde são apresentadas a busca da qualidade e melhoria do ensino como justificativas para a prática da terceirização, através da análise de algumas propagandas da mídia digital deste tipo de empreendimento, além do enfoque de outros conflitos vividos num ambiente escolar, o qual em nossa sociedade, assume o papel de preservar e repassar ideologias e valores.

Capítulo 3- A Prática da Terceirização: esse capítulo discute a prática da terceirização em si, através das análises dos dados coletados na pesquisa, subdividindo-se em:

3.1- Dificuldades para se lidar com a heterogeneidade na escola de educação formal: a padronização e o modelo. Há uma subdivisão onde se analisa a possibilidade de conflitos, a qual pode levar revisão de objetivos educacionais.

3.2- A formação docente na parceria terceirizada: treinamento ou posicionamento crítico? Neste item há uma subdivisão onde são analisadas as possibilidades de brecha nas práticas de terceirização a partir da agência docente. 
3.3- Análise das perspectivas atuais: a terceirização chega à escola pública. Analisa-se aqui, a lei recém assinada pelo governador de São Paulo que prevê a possibilidade da terceirização do ensino das línguas estrangeiras também nas escolas públicas.

\section{CAPÍTULO 1 - AS TEORIAS DOS NOVOS LETRAMENTOS}

\subsection{O Ensino de L.I. praticado nas últimas décadas}

No cenário brasileiro atual, o ensino de língua estrangeira tem sofrido grandes mudanças, especialmente em relação ao ensino formal, notando-se uma insatisfação generalizada em todos os envolvidos no processo educacional: professores, alunos, pais, administradores-educadores.

Pesquisas recentes dentro da área de ensino-aprendizagem de língua estrangeira (UECHI, 2006; OLIVEIRA, 2005; MARTINEZ, 2007), dão conta de que os alunos passam pelos anos escolares sem conseguir ter uma aprendizagem efetiva de uma segunda língua, seja no aspecto linguístico propriamente dito, seja no aspecto comunicativo ou mesmo no aspecto cultural. Alunos, pais e professores repetem discursos de insatisfação propagados vastamente 
pela mídia e pela própria escola, como um discurso já institucionalizado, o qual assegura que língua estrangeira não se aprende na escola. Essa mesma insatisfação reflete-se também em documentos preparados por comissões governamentais como nos Parâmetros Curriculares Nacionais (1998, p.65), como destacado a seguir: “deve-se encontrar maneiras de garantir que essa aprendizagem deixe de ser uma experiência decepcionante, levando à atitude fatalista de que língua estrangeira não pode ser aprendida na escola.”

Embora todos os envolvidos reconheçam o papel fundamental da aprendizagem de língua estrangeira na formação do estudante, os aspectos ressaltados sobre a importância dessa aprendizagem, limitam-se, principalmente, à preparação para o exame vestibular, a possibilidade de maior sucesso no mercado de trabalho ou uma formação continuada em qualquer área profissional.

Nesses mesmos discursos, além desses aspectos, outra grande preocupação em relação ao ensino de língua estrangeira, especialmente o ensino de Inglês, é a globalização. É fato que, nas últimas décadas houve uma relevância acentuada na questão da globalização e na utilização de novas tecnologias que em seus estudos privilegiam também o Inglês. Ao comentar sobre a globalização, Rajagopalan (2003) acentua que aprender uma língua estrangeira, principalmente o Inglês, parece uma atividade natural e ideal para aqueles que querem ter sucesso nesse mundo globalizado, tendo acesso a recursos diferenciados. Em dissertação de mestrado sobre a formação de professores de língua inglesa, ao comentar sobre a atualidade do ensino de línguas no Brasil, Martinez (2007), citando o mesmo autor referido acima (RAJAGOPALAN, 2005), destaca uma outra implicação sobre a língua inglesa que é a de que esta carregaria o status de "língua mais importante do mundo", por causa da globalização. Segundo a citada pesquisadora, essa visão passa por alto o fato de que esta seria uma implicação muito mais de cunho de dominação, e dependendo de como professores e alunos interpretem esses valores intrínsecos ao ensino de língua inglesa, muitas vezes ao terminar o curso, o aluno poderá ter a impressão de que "cresceu culturalmente" e por isso terá mais valor na sociedade pelo fato de ter aprendido uma língua estrangeira com mais status.

Nesse contexto, compreendendo que esse é um quadro que apresenta histórias de sucesso, mas também de acentuadas frustrações, não só na escola pública como também na escola particular, de acordo com os estudos já mencionados, o ensino de língua estrangeira - 
predominantemente o Inglês - tem sido visto como um problema para o qual se tem buscado muitas soluções, das mais simplistas às mais sofisticadas.

Por ser visto como um "problema", o ensino da língua inglesa tem buscado "soluções" para a sua operacionalização. Pesquisando sobre essas possibilidades de soluções para o problema do ensino de Inglês, Uechi (2006), em dissertação de mestrado, analisa em seu estudo - no qual revelou que a língua inglesa foi muitas vezes interpretada como disciplinaproblema - algumas alternativas buscadas como solução. Nas escolas investigadas, as alternativas destacadas na pesquisa foram: a criação de um centro de línguas próprio dentro de um colégio; a utilização de uma disciplina-projeto para o ensino de Inglês em um colégio de ensino médio da rede pública; aulas de revisão para alunos do terceiro ano do ensino médio de escolas públicas visando o ensino de leitura; a parceria entre um colégio particular de ensino fundamental e médio e uma escola de línguas e a terceirização do ensino de Inglês em colégio de ensino fundamental e médio. Esta última proposta será justamente o objeto de estudo desta atual pesquisa.

Essa insatisfação já destacada anteriormente ocorreu também em boa parte da classe de professores os quais empreenderam uma incessante busca por metodologias, abordagens, materiais didáticos revolucionários, técnicas motivadoras, utilização das mais recentes tecnologias de multimídia, enfim, "receitas" que pudessem resolver a percebida ineficiência do ensino de línguas na escola formal. Essa busca por metodologias e abordagens, obviamente, não é uma novidade. Historicamente, a aprendizagem de línguas manteve-se em uma dinâmica de transformação, sempre tendo influência nas formações sociais e vice-versa, de acordo com as mudanças de conceitos e valores não só restritos aos da educação, mas aos valores de escola, conhecimento e aprendizagem, bem como economia e cultura, como um todo. Comentando esse fato, Grigoletto (2004), ressalta em artigo, baseando-se em estudos de Carneiro Leão, que já em 1935, havia uma preocupação com a ineficácia do ensino de idiomas nas escolas brasileiras. Esse professor propunha a aplicação do método direto para o ensino das línguas vivas, a mesma metodologia adotada na França trinta anos antes, que privilegiava a ministração das aulas na própria língua alvo, desde o início do aprendizado. A autora declara que o ensino das línguas vivas sempre foi um dos pontos mais fracos da educação secundária brasileira, colocando também a questão do elitismo em relação ao seu ensino, pois comenta que, fora os filhos de famílias abastadas, ninguém deixava os Liceus ou 
Ginásios sabendo francês ou inglês e que ninguém saia compreendendo a língua oral, quanto mais falando-a ou escrevendo-a (op. cit. p. 454).

Considerando o insucesso de língua estrangeira na escola de educação formal, como já comentado, a busca por metodologias e abordagens de ensino que pudessem ser uma resposta favorável a esse "problema", reforçou-se no próprio fenômeno da terceirização do ensino de língua. Nos institutos de idiomas há uma focalização especial para as metodologias de ensino, as quais são vistas como uma marca particular e tratadas como um diferencial, pois são consideradas um dos principais fatores que conduzirá ao sucesso o processo de ensino.

A fim de destacarmos essa preocupação metodológica sempre presente no ensino de línguas estrangeiras, faremos um breve resumo de como alguns métodos e abordagens se destacaram no ensino/aprendizagem de línguas, considerando o estudo de Richard \& Rodgers (1986).

Os citados autores explanam que na primeira parte do século $\mathrm{XX}$, quando havia uma procura pela objetividade das ciências exatas, criou-se uma nova área de pesquisa, buscando eficiência e método. Foram então desenvolvidos os fundamentos para o ensino de línguas estrangeiras, quando os teóricos, linguistas aplicados, pensaram em procedimentos para o ensino/aprendizagem de línguas baseados em critérios científicos.

Os primeiros métodos desenvolvidos a partir dessa idéia, tiveram como base a gramática, não no sentido tradicional clássico, anteriormente utilizado no ensino de línguas clássicas, mas a partir de estruturas modelares, levando ao surgimento dos métodos situacionais e audiolinguais. Retomando essa época de pré-objetividade, na qual ainda não havia a preocupação científica com o ensino de línguas, citamos o Método Gramatical, que se desenvolveu no século XIX até o século XX, sendo utilizado no ensino de línguas clássicas e, posteriormente direcionado também ao ensino de línguas modernas. Este método tinha como características principais o estudo de regras, a memorização de listas de palavras e a tradução de sentenças, muitas vezes descontextualizadas, a produção oral não era objetivo e a língua real não era considerada; para os professores não havia a exigência de competência comunicativa na língua alvo. Esse modelo do latim clássico para o ensino de línguas modernas começou a ser questionado no início do século XIX devido a fatores variados como mudanças numa sociedade onde o ensino já não era mais tão elitista, onde o intercâmbio com o mundo começava a se tornar imprescindível - uma espécie de primórdio da globalização de 
hoje - surgindo então um mercado para novos métodos de conversação, nos quais se utilizavam frases incipientes e descontextualizadas. Era o início de um programa estrutural, surgido efetivamente na década de 40/50 do século XX. A fonética passava a ter um papel preponderante nessa metodologia de reforma, pois nessa fase, a fala tornava-se mais central. Diferentemente do Método de Gramática e Tradução, a língua materna era evitada. No final do século XIX surge então o método Direto que tinha como características os seguintes princípios: ensinar sempre na língua alvo; utilizar vocabulário e frases do dia-a-dia; ensinar habilidades de fala e compreensão oral, com turmas pequenas; ensinar gramática indutivamente, onde os professores tinham que ter excelente proficiência, ou de preferência serem nativos. Esse conjunto de procedimentos de ensino - que definem um caminho, ou a procura desse melhor caminho para o ensino/aprendizagem de língua estrangeira - inaugurou a era dos Métodos.

Da segunda década do século XX em diante, até os anos 60, desenvolveu-se a Abordagem Oral ou Ensino Situacional, que envolvia alguns princípios sistemáticos de seleção, gradação (organização e a sequência do conteúdo) e a apresentação (conteúdo lexical e gramatical). A teoria de aprendizagem utilizada no Ensino Situacional baseava-se no desenvolvimento de hábitos, portanto um tipo de teoria behaviorista, que pretendia formar hábitos corretos de linguagem através de exercícios de drills e de uma abordagem indutiva para o ensino de gramática. $\mathrm{O}$ professor atuava como modelo perfeito e a aula girava em torno dele - que comandava todas as atividades - das mais complexas às mais livres.

Segundo Maciel (2004), na época da Segunda Guerra Mundial, o exército americano criou um programa de treinamento linguístico, pois havia um grande número de estudantes estrangeiros que precisavam aprender inglês nos Estados Unidos, objetivando a proficiência em conversação. Os princípios aplicados eram estruturalistas e a língua era ensinada através da repetição, dos drills, dos modelos básicos de sentença, que eram memorizados pelos alunos através da repetição estímulo-resposta. Essa metodologia está ligada ao estruturalismo americano, na análise contrastiva e na psicologia behaviorista. Por volta de 1950, essa influência estendeu-se pelo mundo afora, chegando a muitos outros países. O método audiolingual tinha como objetivo principal formar novos hábitos linguísticos no aluno, a fim de levá-lo a comunicar-se, sendo que caberia ao professor controlar esse processo tentando evitar ao máximo, o erro do aluno, pois o erro seria um reforço negativo. A possibilidade de interação era mínima, pois criatividade por parte do aluno poderia fugir do controle pré- 
estabelecido, o qual deveria ser mantido. Destaca-se nesse contexto, o foco na pronúncia e a montagem dos laboratórios de língua para a prática e a repetição, reforçando o aspecto reprodutivo do ensino de língua, segundo um tipo de conceito do que significa interagir. Com o passar do tempo, por suas características estruturalistas, esse método passou a ser questionado, pois já não dava mais conta das reais necessidades dos alunos além de que a própria linguística estrutural enfrentava críticas com o surgimento de novos paradigmas que questionavam teorias behavioristas de aprendizagem.

Surgiu então, o que se conhece como abordagem comunicativa, que embora não sendo considerado um método em si, inaugurou novos pressupostos teóricos onde o poder funcional e comunicativo da linguagem se tornaram o centro da discussão. Os pressupostos teóricos que servem à abordagem comunicativa têm origem em várias áreas disciplinares como a filosofia da linguagem, a pragmática, a sociolinguística e a análise do discurso. Para Richard e Rodgers deve-se citar contribuições de Bakhtin, no conceito de dialogia da língua, Halliday e Widdowson, com questões sobre contextualização e privilégio do uso sobre a forma. As principais crenças dessa abordagem sustentam que a competência linguística ou o domínio da língua por si só, não levam à competência comunicativa; crê-se que há que se desenvolver estratégias e habilidades comunicativas a partir do uso real da língua. A partir dessas idéias centrais, vemos como características dessa abordagem, a tolerância ao erro, sendo ele agora visto como parte de um processo de desenvolvimento de habilidades; além disso, o contexto surge como algo relevante, ao qual os significados e funções da língua devem ser adaptados, num processo de negociação de significado; nesse processo, como afirma Bakhtin, surge o dialogismo do discurso, onde o significado é construído na interação com o outro; nessa busca de significados, o aluno passa a ter um papel como sujeito participante e coautor, não mais passivo; há então a ênfase no trabalho de grupos ou duplas. Embora haja muitas divergências no nível de implementação e no nível dos procedimentos, atualmente, esta abordagem tem sido uma das mais utilizadas e difundidas entre os cursos de idiomas, materiais didáticos, bem como por estudiosos da área.

\subsection{Novos projetos de ensino de L.I. - O Ensino de L.I. em uma perspectiva educacional}


Depois deste breve resumo histórico das metodologias, voltamos a abordar a respeito de como o ensino e aprendizagem de língua estrangeira tem sido considerado algo problemático, agora em âmbito mais amplo. Essa mesma insatisfação, descrita entre os protagonistas da educação, como alunos e professores, também pode ser sentida através da criação de novos documentos pelo Ministério da Educação, propondo uma nova visão e uma nova abordagem para o ensino de língua estrangeira com os Parâmetros Curriculares Nacionais, tanto para o Ensino Fundamental, a partir de 1998, como para o Ensino Médio, a partir de 1999. Recentemente em 2006, uma nova proposta foi elaborada, tendo sido apresentada como orientações curriculares e não mais como parâmetros.

Conforme já mencionado, no trecho a seguir, reitero o destaque dos Parâmetros Curriculares Nacionais de Língua estrangeira do Ensino Fundamental (1998, p.65), ao comentar sobre objetivos, o documento declara explicitamente essa mesma percepção de insatisfação, como nos outros segmentos: “deve-se encontrar maneiras de garantir que essa aprendizagem deixe de ser uma experiência decepcionante, levando à atitude fatalista de que língua estrangeira não pode ser aprendida na escola."

No mesmo documento acima citado, podemos notar ainda uma preocupação com uma mudança de paradigmas em relação aos objetivos do ensino de língua estrangeira, a saber, uma ênfase especial no aspecto educacional do ensino de línguas.

Delineia-se assim, que o ensino de língua estrangeira deve contribuir para o processo educacional como um todo, indo muito além da aquisição de habilidades linguísticas específicas. A descrição dos objetivos vai desde uma nova percepção da natureza e funcionamento da linguagem, apreciação de costumes e valores de outras culturas para desenvolvimento da percepção da própria cultura, até a promoção da aceitação de diferenças interculturais.

Destaca-se ainda que:

A aprendizagem de língua estrangeira no Ensino Fundamental não é só um exercício intelectual... é sim, uma experiência de vida pois amplia as possibilidades de se agir discursivamente no mundo. O papel educacional da Língua estrangeira é importante, desse modo, para o desenvolvimento integral do indivíduo, devendo seu ensino proporcionar ao aluno essa nova experiência de vida (1998, p.37). 
No trecho dos PCNs supra citado, ao se comentar sobre o desenvolvimento integral do indivíduo, pode-se passar a impressão de que o ensino de línguas estrangeiras poderia suprir as necessidades do mesmo, com conteúdos, preenchendo-o até que se tornasse "completo". No entanto, interpretamos que o desenvolvimento do sujeito não visaria a ser integral, tendo como prerrogativa a heterogeneidade constitutiva dos sujeitos, e que significa, outrossim, permitir que o indivíduo se envolva por experiência em todos os processos ideológicos e discursivos da sociedade na qual está inserido, a fim de que ele compreenda sua posição dentro da mesma, porque ocupa este lugar e suas possibilidades de mudança e transformação.

Há que se destacar que o conceito de indivíduo-sujeito ao qual nos referimos aqui, é aquele cindido, constituído de forma heterogênea, marcado sócio-historicamente por variados discursos que se inscrevem em formações ideológicas. (CORACINI, 2000). A construção de suas identidades são um processo sócio-histórico-ideológico ininterrupto, heterogêneo, contraditório, fragmentado, inacabado e contingente (HALL, 1997; PENNYCOOK, 2001).

Em outro documento, nas OCEM, 2006, com as mesmas prerrogativas de orientação para o ensino de línguas para o ensino médio, já um pouco mais recente, visto tratar-se de uma revisão feita em 2006, podemos notar a mesma preocupação a respeito da insatisfação com o ensino de línguas na escola formal, através de citações de duas pesquisas, as quais salientam os resultados desiguais no ensino de Inglês na escola formal e o ensino na escola de idiomas. A primeira citação descreve que

o sistema educacional brasileiro coloca no mercado de trabalho professores despreparados e muitos recorrem aos cursos de especialização em busca de uma regraduação, o que naturalmente não encontram. Esse contexto reforça, dia-a-dia, o preconceito de que só se aprende língua estrangeira em cursos livres (apud DUTRA e MELLO, 2004, p. 37).

A segunda pesquisa (UECHI, 2006) destacada no documento ressalta a busca de soluções para o fracasso do ensino de inglês da escola formal através da implementação de estruturas paralelas como convênios com cursos de idiomas, montagem de centro de línguas e terceirização do ensino.

Neste documento verifica-se ainda, um conflito de objetivos do ensino de língua estrangeira, contrapondo a escola de educação formal e a escola de idiomas, esta última, vista muitas vezes como sendo um modelo de eficiência na aprendizagem de línguas. No entanto, observa Uechi, os objetivos da escola formal e da escola de idiomas são diferentes, pois sua 
finalidade é diferenciada: a primeira devendo se concentrar nos aprendizes e na formação desses; já a segunda, concentrando-se nos aspectos linguísticos e instrumentais do ensino de línguas (OCEM, 2006, p.89-91).

Como vimos, nos variados níveis do processo educacional, desde a preocupação governamental na produção das orientações curriculares, passando por pesquisadores, da formação de professores até os próprios alunos, incluindo pais, professores e pedagogos, a insatisfação ou inadequação do ensino de língua estrangeira nas escolas formais tem, em consequência da frustração nos envolvidos, gerado uma busca por solução.

Entre essas buscas de solução para o problema da ineficácia do ensino de línguas na escola de educação formal, soluções essas aparentemente rápidas, eficazes e de fácil implantação, surgiram as parcerias com as escolas de idiomas já atuantes no ensino de língua estrangeira. Retomando o objeto desta pesquisa, este constitui-se, portanto, no estudo de uma dessas parcerias de um instituto de idiomas com uma escola regular, visando ao ensino de língua estrangeira.

As escolas de idiomas, na percepção da ineficiência do ensino de línguas nas escolas de educação formal, identificaram na abertura para a terceirização uma grande oportunidade de atuação. A partir dessa percepção, foram então disseminadas as parcerias em várias modalidades, sendo oferecidos os seguintes serviços: implantação de um núcleo de idiomas na própria escola; parceria com a instituição de ensino em caráter extracurricular ou intracurricular; ou ainda no formato de convênio, onde os alunos têm descontos especiais nas unidades da escola de idiomas. São oferecidos ainda, vários tipos de assessoria como: material didático e material de apoio (vídeos, CD-ROMs, etc), treinamento de professores, workshops.

Esta pesquisa focaliza especificamente a parceria ou terceirização de serviços no formato intracurricular, onde o contratante - a escola particular - delega a disciplina - no caso, língua estrangeira, Inglês - para a instituição contratada, uma escola de idiomas, que dispõe de seus métodos, recursos didáticos e professores no ensino de língua estrangeira contratado.

\subsection{Subsídios teóricos para proposta educacional de L.I.}

\subsubsection{Panorama histórico}


O termo Letramento, traduzido do inglês literacy, passou a ser usado em Português com os estudos da Educação e das Ciências Linguísticas, a partir da segunda metade dos anos 80. Na língua inglesa o termo illiteracy tem sido corrente desde 1660 , segundo registro do Oxford English Dictionary, mas seu antônimo literacy surgiu apenas no final do século XIX, em resposta às mudanças históricas das práticas sociais, com as novas necessidades sociais do uso da leitura e da escrita (SOARES, 2005).

Em contraponto à noção de alfabetização como simples aquisição da tecnologia de decodificação do código da leitura e da escrita, o novo termo letramento surgiu para dar conta de uma nova realidade social onde não basta apenas ler e escrever, mas sim, atribuir sentidos, a partir dos contextos e dos meios de sua produção, possibilitando que o sujeito interaja e seja agente nas práticas sociais. Além disso, com o avanço da tecnologia e a multiplicação de possibilidades de produção de sentido, a leitura e a escrita ultrapassaram os limites do código alfabético, sendo que outros códigos, visuais, auditivos, sensitivos, participam da produção de sentidos fazendo parte integrante das práticas sociais dos indivíduos.

Importante salientar que todo esse processo embasa-se em profundas mudanças epistemológicas nas quais a visão de linguagem tem especial importância; Barton (1994) afirma que toda a visão de letramento tem como premissa uma visão de linguagem não como um sistema fixo e estável, mas como algo em construção, tanto no contexto histórico quanto no individual, ou seja, não apenas os contextos históricos com seus discursos vigentes participam da produção de sentidos, mas também o uso individual que se faz da linguagem localmente pode transformar e movimentar esse sistema.

Nessa visão a linguagem apresenta, portanto, uma subjetividade tanto no nível sóciohistórico, quanto no nível individual, o que neste nível poderíamos chamar de agência. Embora sob contextos ligeiramente diferentes, alguns autores reafirmam o caráter de escolha e de ação na definição de agência. Ao comentar a importância da linguagem como elemento crucial na constituição da subjetividade, Pennycook (2003) declara que o indivíduo assume posições dentro de diferentes discursos e ao fazê-lo, exerce algum tipo de escolha para participar deles, tendo assim uma forma de agência.

No contexto escolar, especificamente, Giroux (1997) concebe a agência em um sentido mais político, encarando os professores como intelectuais, como estudiosos e profissionais ativos e reflexivos, capazes de utilizar formas de pedagogia que incorporem 
necessidades e interesses políticos emancipadores. Segundo o mesmo autor, essas formas de pedagogia devem tratar os estudantes como agentes críticos, tornar o conhecimento problemático, utilizando o diálogo crítico, dando voz ao estudante em suas experiências de aprendizagem. Portanto, a agência nessa visão política, objetiva a formação de cidadãos ativos e críticos.

Para Jordão (2009), a concepção de agência está relacionada a autonomia e reflexividade, baseando-se em conceitos freirianos de emancipação e conscientização (Freire, 1996). Sob essa perspectiva, agência pressupõe uma abertura para as diferenças, uma percepção do contexto e seus limites bem como formas de negociar ou resistir a eles, fazendo escolhas e encontrando possíveis caminhos de significação; portanto, de certa forma, ao mesmo tempo restringindo e permitindo. Assim, agência teria o papel fundamental de produzir e reconhecer novas formas de saber e conhecimento, não sendo estes interpretados como certos ou errados, bons ou maus, mas nas palavras de Jordão (2009) sendo reconhecido como

"prática social que torna certos saberes melhores ou piores aos olhos de grupos sociais específicos; este conceito de agência permite aos professores e alunos engajar-se num diálogo crítico com as práticas de construção de sentidos, tanto suas, quanto dos outros" (p. 102).

Voltando a comentar sobre as mudanças epistemológicas, Kress (2003) declara que os processos de transformação contemporâneo da pós-modernidade, bem como as possíveis transformações futuras, não se referem só à linguagem, pois esta seria apenas um dos modos de significação e, acrescenta que as teorias de linguagem conhecidas não dão mais conta desses outros modos semióticos.

Antes de 1970, de acordo com Soares (2005), na educação formal, o conceito de leitura e escrita tinha um cunho psicológico, centrado em habilidades individuais. $\mathrm{O}$ letramento, no inglês literacy, aparecia apenas no ensino não formal, especialmente relacionado ao ensino de adultos. No Brasil os termos usados eram alfabetização e analfabetismo, sob esse mesmo contexto.

As definições de letramento tradicionalmente eram usadas em relação à aquisição de leitura e escrita, ou ainda particularmente em relação a adultos não-letrados, tratando-se de programas específicos de alfabetização. 
Segundo Lankshear e Knobel (2003) alguns fatores tornam-se importantes para incrementar o desenvolvimento de teorias específicas sobre letramento, a partir de 1970; dentre eles, destacamos os seguintes: primeiramente o movimento de educação radical desenvolvido por Paulo Freire, no final dos anos 60 e início dos anos 70, onde o conceito de letramento era "ler as palavras e ler o mundo", envolvendo muito mais do que um mero decodificar de signos linguísticos, mas sim a construção de uma prática social, que envolvia reflexão crítica e ação; um segundo fator de desenvolvimento dos letramentos nas novas perspectivas educacionais foi a descoberta, especialmente nos Estados Unidos, de uma crise de preparo para o enfrentamento das novas demandas econômicas e sociais, numa sociedade pós-industrial, onde os alunos depois de passar pelas instituições escolares, não davam conta das mudanças nas organizações e instituições que tinham de enfrentar no dia a dia; e finalmente, o desenvolvimento das perspectivas socioculturais dentro dos estudos da Linguagem e das Ciências Sociais (GEE, 1996).

Conclui-se, portanto, que a partir dos anos 70, o letramento ganha ênfase na educação formal, já não mais restringindo-se a um cunho psicológico, mas sim, expandindo-se para um cunho sociológico. Resumidamente, isso aconteceu por estas três razões gerais: trabalho de Paulo Freire voltado à consciência crítica; pelo pós-industrialismo que exigia uma mudança do modo mecanicista de trabalho até então vigentes, para um modo de pensamento e ação com a necessidade de iniciativa e tomada de decisões; e finalmente, pela perspectiva teórica sociocultural nos estudos de Linguagem e Ciências Sociais, integrando outros campos da ciência (LANKSHEAR e KNOBEL, 2003).

Como consequência desses novos estudos houve certamente mudança de conceito e nomenclatura, sendo o termo largamente utilizado dentro dos sistemas oficiais de ensino passando-se de uma perspectiva de letramento psicológica para uma perspectiva de letramento como prática social; no entanto, não aconteceram mudanças práticas em termos educacionais.

Sob essa perspectiva sociocultural desenvolveu-se uma concepção bem mais estruturada colocada por Green $(1988,1997)$ em um modelo de três dimensões, a saber; operacional, cultural e crítico. Sob essa visão destaca-se que o letramento deve ser visto como tendo essas três dimensões de aprendizagem e prática, as quais trariam em si aspectos da linguagem, significação e contexto, sendo que nenhuma prioriza outra e são compreendidas como uma prática simultânea. 
A dimensão operacional tem seu foco na linguagem, incluindo competências, procedimentos e técnicas que envolvem também habilidades de se lidar com o sistema da língua escrita de forma proficiente, mas não só, pois inclui adequação dos contextos nos quais se processa; a dimensão cultural tem a ver com a competência dos sistemas de sentido dentro das práticas sociais, especificamente, o contexto; e a dimensão crítica envolve a percepção de que todas as práticas sociais, e em consequência os letramentos, são socialmente construídos e seletivos, incluindo e também excluindo representações e classificações de valores, padrões, regras. A dimensão crítica preconiza a percepção de que, através dos letramentos o indivíduo não meramente é capaz de participar dessas representações, mas participa de sua produção e também é capaz de participar de sua transformação (GREEN, 1998; GEE at al 1996 apud LANKSHEAR e KNOBEL, 2007).

Ressalta-se ainda que o impacto das novas formas de comunicação, das novas tecnologias bem como da circulação de informações mudaram e consequentemente, estão mudando as demandas de aprendizagem tanto nas dimensões operacionais quanto culturais. Essas diversidades culturais e linguísticas, sob o impacto das novas tecnologias de comunicação em constante expansão, estão mudando as necessidades de aprendizagem dos alunos e assim, as necessidades dos letramentos tornam-se múltiplas e diversificadas também.

Os estudos dos novos letramentos dentro das Ciências Sociais e Linguísticas, sob um novo paradigma, expandem as suas bases em relação aos aspectos psicológicos antes vigentes nos estudos da linguagem, assumindo um novo paradigma de investigação, com bases sociológicas.

Assim, com base nas mudanças em termos de tecnologia, instituição, mídia, economia e outros meios, que impactaram e transformaram as práticas sociais nas diversas esferas da vida, também mudaram os modos de produzir, distribuir, trocar e receber textos. Com base nessas transformações surgem os Novos Letramentos ou Multiletramentos (GEE, 1990; COPE e KALANTZIS, 1996).

Veremos agora dois aspectos essencialmente importantes que acabaram por construir essa nova perspectiva nas linguagens e práticas sociais, a saber, a globalização e a virada tecnológica, a era digital.

\subsubsection{Globalização}


Esse tema tem estado em foco nas últimas décadas, gerando tanto interesse quanto controvérsia, pois sua amplitude vai desde as Ciências Econômicas até as Ciências Políticas, bem como às Ciências Sociais. Por definição, segundo Coatsworth (apud Bauman, 1998) globalização seria "o que acontece quando o movimento de pessoas, bens ou idéias entre países e regiões acelera" (p. 1).

Sob uma perspectiva um pouco mais humanística, Bauman (1998) destaca que antes do fenômeno da globalização o mundo buscava e se mantinha, ainda que precariamente, numa tentativa de equilíbrio entre duas potências politicamente definidas que mantinham e se apropriavam em variados níveis, político, cultural, social, a saber, o eixo capitalista americano e o eixo socialista soviético ${ }^{2}$. Havia "controladores" e um certo controle da totalidade. Com o fim da potência soviética, o mundo deixou de ser uma totalidade e agora assemelha-se a um “campo de forças dispersas e díspares” (op. cit. p. 66), onde o controle se encontra distribuído por várias e também novas lideranças e ninguém mais parece estar no controle.

É nessa dispersão de controle e ausência da totalidade, segundo Bauman (1998) que subjaz o conceito de globalização, nas palavras do autor:

O significado mais profundo transmitido pela ideia de globalização é o do caráter indeterminado, indisciplinado e de auto-propulsão dos assuntos mundiais; a ausência de um centro, de um painel de controle, de uma comissão diretora, de um gabinete administrativo (p. 67).

2 A Política dos Blocos surgiu após a Segunda Guerra Mundial, como consequência da chamada Guerra Fria, que opôs a União Soviética aos Estados Unidos: duas nações militar e politicamente poderosas que representavam sistemas ideológicos divergentes e que lutavam pela hegemonia mundial. A partir de então, esses dois Estados colocaram em prática uma política expansionista, visando a ampliação de suas respectivas zonas de influência. A União Soviética manteve um rígido controle sobre os países socialistas do Leste Europeu e fomentou processos revolucionários em todos os continentes, com objetivo de expandir o comunismo pelo mundo. Os Estados Unidos, por outro lado, reagiu com uma política de contenção do avanço soviético e ampliação de sua respectiva zona de controle e influência sobre os países capitalistas. O equilíbrio entre os Blocos foi quebrado com a desintegração da União Soviética, em 1991, e do socialismo no Leste Europeu. O mundo transitou de uma ordem internacional polarizada (equivocadamente chamada de ordem bipolar) para uma ordem internacional que pode ser concebida como multipolar, devido à existência de vários centros de poder. http://educacao.uol.com.br/sociologia/politica-dosblocos.jhtm 
Ideias anteriores como as de "universalização" ou mesmo de "civilização", substituídas pelas ideias da globalização, mantinham um caráter idealista de intenção de produção de ordem, melhoria das condições de vida em escala global, aumentando oportunidades para todos e tinham também a pretensão de tornar essas oportunidades iguais.

A globalização por sua vez, embora muitas vezes velada por esses mesmos ideais positivistas, é marcada pela força motriz do neoliberalismo - o mercado - enquanto isso acontece o consequente enfraquecimento de outras instituições como o Estado, que quanto mais fraco, mais atende aos interesses dos mercados mundiais (BAUMAN, 1998; SUÁREZOROZCO, 2007).

Como vimos, o tema globalização tem criado inúmeros debates e transformações nas áreas econômica, política e social numa tentativa de adequação às novas necessidades que esse fenômeno faz despontar. Uma das áreas que tem sido afetada e também o afeta, não só no campo teórico, mas também pragmático, é a educação.

Toda essa dinâmica de transformação, tanto dos sistemas institucionais, quanto dos próprios indivíduos mostra que a globalização tem uma implicação incisiva sobre a educação; por outro lado, considera-se uma via de mão dupla, posto que esta teria também um papel fundamental na adequação e na preparação dos cidadãos que atuam nessas novas realidades globalizadas.

Segundo Orozco e Qin Hilliard (2004), esse seria o principal desafio da educação no século XXI, a saber, mudar o preparo dos cidadãos de um modelo fabril pós-industrial, para um outro, onde os cidadãos devem estar preparados para exercer funções interconectadas e rápidas mudanças num mundo globalizado. Ainda conforme os mesmos autores, essas transformações globais vão requerer novas habilidades dos jovens, as quais deveriam ser aprendidas nas escolas; no entanto, para Suárez-Orozco e Qin Hilliard (2004), essas habilidades estão muito além do que os sistemas educacionais atuais podem oferecer.

Embora possamos questionar essa visão neoliberal de que a educação deva preparar os cidadãos para o trabalho e manutenção dos sistemas econômicos e sociais vigentes, não podemos desprezar as novas necessidades impostas pelas massivas transformações pelas quais as sociedades têm passado, bem como suas implicações nas instituições educacionais. Ademais, ainda que se pense numa educação que prepare cidadãos com visão crítica, com possibilidade de autonomia e de agência para a transformação desses sistemas, e não apenas 
para reproduzi-los, há que se pensar em adequações às novas realidades a que a globalização nos impele.

Escobar (2007) comenta que democracia com caráter ocidentalizado, afirmação de liberdades individuais e o consumismo baseado no mercado, são ideias neoliberais que através da globalização têm sido impostas com uma certa violência de dominação, as quais têm atingido todas as culturas (hemisfério sul e oriente) como se fossem desejos globais. No entanto, a chave para se resistir a esse tipo de imposição estaria na possibilidade de caminhos que considerem novas perspectivas epistemológicas baseadas em sentidos múltiplos, complexidade, heterogeneidade, ao invés da manutenção da valorização da padronização e da homogeneidade, com o apagamento dos conflitos (JORDÃO, 2009).

Vemos assim, que os mesmos pontos nos quais as ideias neoliberais globalizadas se fundamentam para uma educação reprodutivista, são também as bases que nos impelem a buscar alternativas para uma nova visão educacional que priorize a crítica e a transformação. Sob esse locus, baseado nas teorias pós-coloniais e na educação crítica, a educação nos discursos globalizados mostra-se como um desafio que deve constituir não só novas habilidades cognitivas, mas também relações interpessoais e culturais diversificadas e sofisticadas, que preparem os indivíduos para se engajarem em todos esses processos.

Suárez-Orozco (2007) ressalta dois domínios, que segundo ele, representam os grandes desafios em particular para a educação nessa era globalizada: o domínio da diferença e o domínio da complexidade. Num contexto marcado pelos mais variados padrões sociais e culturais, étnicos, religiosos, linguísticos, de gênero e de raça, lidar com as diferenças tem se tornado o grande desafio para os educadores, pois o contexto escolar dentro da sociedade globalizada também se tornou multicultural.

A formação educacional desse cidadão deverá levar em conta que ele deve estar preparado para lidar com os conflitos das diferenças, negociar posições, visualizar múltiplas perspectivas sobre fatos e padrões estabelecidos, ou seja, um contexto onde o global e o local entram em intersecção, onde todas as fronteiras tanto no nível social quanto no individual, tornam-se mais fluidas e inconstantes. Os contextos globalizados geram maior complexidade que, por sua vez, devem gerar novas fórmulas de analisar e solucionar problemas. Flexibilidade, agilidade, uma compreensão multidisciplinar são demandas que a vida globalizada impõe às novas sociedades. Milhões de crianças e jovens estão crescendo nesse 
mundo globalizado e estão tendo a sua formação defasada ao passar pelos sistemas educacionais que, tradicionalmente, são adversos a mudanças.

Sob esse contexto de mudança e transformação de paradigmas as teorias dos multiletramentos abordam esse novo cenário e apontam para alternativas no campo educacional, com possibilidades de responder a essas novas demandas sociais e individuais que as novas práticas sociais e globalizadas fizeram emergir.

No complexo contexto escolar, destaca-se o campo das linguagens e dentro deste, especificamente, o estudo do inglês como língua estrangeira, parte do foco desta pesquisa. Desnecessário seria dizer que neste cenário até então descrito, o mundo globalizado e sua sociedade pós-moderna, o conhecimento de línguas estrangeiras é um importante elemento que está diretamente ligado à importância das informações e sua produção em larga escala com total rapidez, bem como ao próprio mercado econômico, principalmente com sua ligação ao mundo do trabalho na sua visão capitalista.

Nesse ponto, ao lembrarmos os ambientes de trabalho modernos da sociedade globalizada, destacamos e discutimos a posição da língua inglesa, que tem sido vista como a língua internacional de comunicação e também como língua franca (JORDÃO, 2009). Ressalta-se que esse poder conferido à língua inglesa não tem nada a ver com características próprias inerentes a ela como sistema ou estrutura, mas sim, seu poder residiria em quem a usa e para que a usa, destacando que os sistemas linguísticos estão ligados à produção e distribuição do conhecimento, e como afirma Foucault, conhecimento e poder são inseparáveis (1996). Como já visto anteriormente, no cenário globalizado pós-moderno, o poder é definido principalmente por "ter ou não ter" (JORDÃO, 2009), e esse tem sido um princípio estabelecido pela lógica neoliberal e disseminado globalmente através de ideologia, culturas, identidades, linguagens e, consequentemente, pelos modos de interpretação ou de produção de sentidos.

Partindo do pressuposto que a língua não só media as relações, nomeando as experiências, mas simultaneamente participa da produção de sentidos, construindo-os, acaba assumindo uma força de legitimação e distribuição do conhecimento, que determinará posições de poder e autoridade histórica, social e política. A língua inglesa tem assumido essa posição no contexto atual e essa autoridade e poder tem sido ainda mais acentuada e disseminada, cremos nós, pelos processos de globalização. 
Sendo assim, entende-se que ensinar e/ou aprender inglês como língua estrangeira na escola de ensino fundamental e médio, hoje, envolve priorizar aspectos reflexivos e críticos alargando as possibilidades de interpretação, o que poderia se realizar, dentre várias propostas, por meio das bases teóricas dos multiletramentos, podendo assim ser um aspecto de transformação e participação ativa nas comunidades atuais.

Através de uma educação linguística crítico-reflexiva, o conhecedor ou falante do inglês sendo visto como aquele que tem uma posição privilegiada pode conhecer criticamente tanto o poder dessa posição quanto a construção dela; por outro lado, a multiplicidade de aspectos que se inserem nesse discurso hegemônico da língua inglesa, também pode ser interpretada como uma possibilidade de abertura, ou uma brecha, para o reconhecimento e relacionamento da multiplicidade cultural com o diferente, o heterogêneo.

Assim, o estudo da língua estrangeira, especificamente o inglês, poderia ser revisto na sua função educativa. A visão muitas vezes atribuída a ele na sociedade capitalista de que é um elemento determinante de status e sucesso, ou um mero mediador de contato com o mundo globalizado, pode se expandir. Por meio de uma perspectiva educacional dos multiletramentos, a aprendizagem de uma língua estrangeira cria a possibilidade de compreender e desafiar as identificações e representações dessa língua dominante, revelando os conflitos criados pela multiplicidade de sentidos que surgirem, promovendo, tanto para os estudantes quanto para professores, diferentes visões do papel do idioma inglês, tanto no contexto local quanto global. Essa percepção poderia emergir por meio de constantes questionamentos de ações individuais e das práticas sociais nas quais os indivíduos que a utilizam se engajam.

\subsubsection{A era digital}

O termo digital nos remete a uma associação imediata com o computador, associação essa correta, pois essencialmente, o que os computadores fazem é trabalhar as informações em forma de dígitos. No entanto, atualmente ao usarmos o termo, abrangemos não só o computador, mas tantas outras formas tecnológicas que dia a dia se renovam e transformam as nossas práticas sociais. 
Essas mudanças tecnológicas não modificaram apenas os meios de acesso a informações ou a forma de acessá-las. Mudaram, outrossim, as nossas relações com o mundo ao redor. A noção de tempo, espaço e até mesmo de realidade transformaram-se, mudando não só algumas práticas, mas também as relações de troca de poder e de envolvimento, tanto em nível individual quanto institucional.

Lankshear e Knobel (2003) falam em mudanças de organização mental usando alguns conceitos apontados por Negroponte (1995) os quais colocam as mudanças tecnológicas em termos de mudanças de como pensar a realidade. Segundo essa ideia, por séculos estávamos acostumados com a noção de que todas as coisas eram formadas por átomos e, com base nisso, foram desenvolvidos conceitos, leis e procedimentos que explicavam e lidavam com o mundo natural, sendo esse mundo capturado de forma analógica. Entretanto, com a virada tecnológica, os atos do mundo físico transformaram-se em bits do mundo digital, trazendo consigo novos conceitos, crenças, orientações do conhecimento, que por sua vez também transformaram nossa visão do mundo e nossa relação com ele.

Um exemplo simples e muito significativo em termos de mudança dos conceitos é a noção de espaço e tempo: o fato de como a transferência ou armazenamento de informações no modelo tradicional difere do modelo digital, pensemos em quanto tempo seria gasto para se escrever um texto de dez páginas a caneta e enviá-lo para um determinado lugar, e quanto de tempo seria gasto para digitá-lo e enviá-lo por email. Imaginando que se multiplicássemos isso por cem textos diferentes, quanto de tempo gasto para fazê-lo e espaço para armazená-los seria necessário (COSCARELLI e RIBEIRO, 2005)? Com esse simples exemplo é fácil concluir que a tecnologia digital mudou radicalmente nossa percepção sobre espaço e tempo, o mesmo acontecendo em outros níveis com diversos outros conceitos.

Historicamente, as mudanças tecnológicas têm tido uma relação determinante com o comportamento humano, nas relações sociais e até mesmo na própria organização social. Ademais, as mudanças operadas pela tecnologia afetam a sociedade como um todo, carregando suas consequências através e apesar de classes diferentes, diferentes contextos geográficos ou culturais. Um exemplo desse fato é a evolução da tecnologia da escrita com a invenção da imprensa. É certo também que a difusão tecnológica obedece a esferas sociais e é limitada por variados níveis de contextos de uma vasta gama de fatores sociais, culturais e até geográficos, que podem limitar ou facilitar o acesso e a participação às novas tecnologias (COPE e KALANTZIS, 2000). A tecnologia emerge em contextos históricos específicos e 
torna-se parte de uma trama social diversa, moldando e sendo moldada por práticas sociais ali vigentes.

Além da mudança de conceitos como de tempo e espaço surgem também novas instituições com novas relações de poder, novas formas de socialização em comunidades virtuais com possibilidades de diferentes políticas de identidade e também de agência. Em nível individual, salientamos essas mudanças em relação às linguagens e às interpretações em três espaços da existência humana: a vida profissional, a vida pública, relacionada à cidadania e também a vida pessoal. Nesse cenário de notável mudança no relacionamento com a tecnologia, em termos de linguagem, as exigências de letramento foram mudando e continuarão a mudar sob a influência e o impacto das novidades tecnológicas, conforme salientam os autores Cope e Kalantzis (2000).

Assim, uma nova configuração de letramento é colocada: além de um metaconhecimento de diversos sistemas de significados, domínio de habilidades técnicas e analíticas também há a necessidade de um enfoque na capacidade de compreensão e interpretação desses sistemas e habilidades que operam essas novas relações de poder que marcam os novos espaços dessas práticas sociais.

Os multiletramentos parecem se encaixar como uma possibilidade de um caminho pedagógico para lidar com essas transformações por ter suas bases nas interpretações múltiplas, no hibridismo, na heterogeneidade e na construção do conhecimento a partir dos contextos e da subjetividade. No ciberespaço, como o significado muda em diferentes mídias, com diferentes gêneros e contextos; a multiplicidade dos textos digitais eletrônicos baseados em noções de hibridismo, intertextualidade e hipertextualidade, exigem uma nova visão, um novo jeito de olhar, um letramento crítico.

Os desafios educacionais em relação a essa virada tecnológica e, consequentemente epistemológica, concentram-se principalmente em dois pólos: o reconhecimento de uma evidente desigualdade de acesso aos bens tecnológicos por questões sócio-econômicas marcadas pela sociedade capitalista, e o grande desafio de lidar com o hibridismo e a heterogeneidade numa instituição, a escola, ainda tão marcadamente linear e baseada em conceitos onde a uniformidade e a igualdade são vistos como objetivos finais.

Pesquisadores e educadores tem se engajado em reconhecer essas transformações e sua influência nos espaços educacionais, como também em aprender com elas integrando-as a 
esse espaço, com tentativas de mudanças de currículos embasados numa filosofia aberta à transformação, à multiplicidade e agência.

\subsubsection{Os Multiletramentos e o ensino de língua estrangeira}

Muitas pesquisas têm sido realizadas dentro da área da Línguística Aplicada sobre a aquisição de segunda língua e o ensino-aprendizagem de uma língua estrangeira, onde inúmeras teorias são apresentadas. Essas teorias diferem desde o conceito que se tem de língua, como estrutura inata ou como instrumento de pensamento e de ação, até e, principalmente, em como acontece a aquisição inicial dessa segunda língua - o inatismo de Descartes (1637) e em oposição, o ambientalismo de John Lock (1690) (PAIVA, 2009).

Com os estudos de autores como van Lier (1997), Larsen-Freeman (1997) e Cameron (2008) surge uma nova perspectiva que tenta equilibrar esses dois pólos - natureza e instrução - passando a ver o indivíduo aprendiz como um agente em interação contínua com elementos do ambiente (PAIVA, 2009). Essa teoria para a aquisição de segunda língua é chamada de teoria do caos.

Essa teoria nos parece bastante condizente com a visão de língua como prática social, na qual se baseiam as teorias dos Multiletramentos, especialmente pelo fato de considerar o aprendiz de segunda língua, como um agente na construção do conhecimento. Sob essa perspectiva, a linguagem como elemento de agência, não só media a atuação do indivíduo na cultura e na sociedade, como também e, ao mesmo tempo, constrói o discurso em que se insere, bem como sua própria identidade, fragmentada e heterogênea, que se mostra em parte e em parte se constrói.

Retomando o conceito de letramento como forma de representação e comunicação construída socialmente por variados modos semióticos, entre eles a linguagem, destacamos que, nesse processo, a noção de uso da linguagem não se limita às fontes discursivas já existentes, mas refaz constantemente essas fontes num processo de ação e interação, construção e reconstrução denominada por Kress (2003) e Cope e Kalantzis (2000) como design. Sob esse conceito, mesmo o uso de uma segunda língua pelo aprendiz, não se limitaria à capacidade de escolher o correto dentro de um sistema linguístico existente já estabelecido, 
mas sim, de usar essa competência em múltiplas possibilidades de escolha nos diversos contextos, não como mero usuário, mas sim como agente produtor e transformador de sentidos.

A proposta dos Multiletramentos de situar o aprendiz como um agente, como tendo parte integrante na construção de seu próprio conhecimento, o qual envolve o reconhecimento das diferenças e as negociações dos possíveis conflitos que surgirem, as possibilidades de interpretações na construção de sentido, além de uma atuação crítica não só diante do sistema já pronto, mas também diante de sua própria ação de escolha, parecem adequar-se às atuais exigências da aprendizagem de uma segunda língua que priorizam objetivos não apenas voltados para a reprodução, mas com possibilidades de atuação crítica e, eventualmente, de transformação, como visto nas propostas das últimas décadas. 


\section{CAPÍTULO 2 - A TERCEIRIZAÇÃO DO ENSINO DE IDIOMAS: UMA PROPOSTA EDUCACIONAL?}

\subsection{Neoliberalismo: contextualizando a terceirização do ensino de idiomas}

Ao considerarmos o fenômeno educacional da terceirização, especificamente ligado às instituições privadas de ensino de idiomas, não poderíamos deixar de considerar o contexto econômico no qual estas atividades se inserem, tendo suas consequentes marcas também no campo político e social.

Portanto, neste capítulo faremos uma breve passagem histórica da doutrina econômica que não só propicia o surgimento de fenômenos como esse, mas também promove sua sustentação.

Segundo Minto (2006), o Neoliberalismo, como termo, foi usado em duas épocas diferentes, com significados semelhantes: na primeira metade do século XX, significava a doutrina proposta por economistas para adaptar os princípios do liberalismo clássico às exigências de um Estado regulador e assistencialista; enquanto que na década de 70 passou a significar uma doutrina econômica que defendia a liberdade absoluta do mercado e restringia a intervenção estatal sobre a economia.

(http://www.histedbr.fae.unicamp.br/navegando/glossario/verb_c_neoliberalismo1.htm)

O liberalismo clássico tinha como proposta os direitos básicos do cidadão, entre eles, o direito à educação; enquanto que o neoliberalismo pauta-se nos direitos do consumidor, em detrimento das liberdades públicas e democráticas e ainda contesta a participação do Estado no estabelecimento dos direitos sociais, criando assim, uma regressão no campo social e político. O grande mote do neoliberalismo pauta-se na idéia de que a economia é autoregulável, capaz de vencer as crises e aos poucos, distribuir benefícios através das camadas sociais, sem a intervenção do Estado. A liberdade que postula, é a liberdade econômica das grandes organizações, desprovida da face política democrática do liberalismo clássico (SILVA, 1996).

Assim, o Neoliberalismo como uma doutrina econômica, embora retomando do liberalismo clássico muitas das suas concepções, como por exemplo, a importância do 
indivíduo como o centro de suas relações sociais, valorizando a competição, o crescimento e a evolução pessoal, a liberdade e o direito de propriedade, enfatiza, acima de qualquer característica relevante, a competição do mercado. Surge a grande marca do Neoliberalismo: o mercado, que doravante assume a posição de instituição.

Com o Neoliberalismo, o mercado soma-se agora às instituições socialmente reconhecidas como o eram até então, a igreja, o Estado, a escola, etc.; cabendo a ele, agora, atuar e regular não só as relações econômicas a ele pertinentes, como também todas as outras relações da sociedade, explícita ou implicitamente.

Historicamente, o liberalismo clássico começa a declinar lentamente no final do século XIX e com a grande quebra da Bolsa de Valores de Nova York, em 1929, e a consequente grande depressão, cai em total descrédito, enquanto vão ganhando força as idéias de Keynes, com teorias de forte intervenção do estado na economia. Essas teorias foram implantadas tanto no governo americano de Franklin Roosevelt, como no governo de Adolph Hitler na Alemanha. Logo após a Segunda Guerra Mundial, na região da Europa e da América do Norte, onde o capitalismo tinha sua maior força, começava a surgir o fenômeno do neoliberalismo, ainda como uma reação teórica e política contra o Estado intervencionista e de bem-estar. Considera-se que seu texto de origem foi $O$ Caminho da Servidão, de Friedrich Hayek (1944), que tinha como mensagem básica uma crítica à social-democracia - alvo do partido trabalhista inglês - a qual conduziria a sociedade inglesa a um desastre, comparado por ele ao nazismo alemão, como uma "servidão moderna". A princípio, suas idéias não tiveram muita aceitação, mas criou-se um grupo que a partir de 1947, se reunia a cada dois anos, para preparar as bases de outro tipo de capitalismo, onde as regras econômicas seriam dispostas pela própria competição do livre mercado (ANDERSON, 1995).

A partir de 1944, os países ricos criaram acordos e estabeleceram regras intervencionistas para a economia mundial, entre elas, a criação do Fundo Monetário Internacional (FMI). Os 30 anos que se seguiram, até o início da década de 1960, foram considerados os "anos dourados" das economias capitalistas.

No entanto, ao final da década de 60, começa uma instabilidade econômica causada por choques sucessivos nos preços mundiais do petróleo, ocasionando o surgimento de um forte movimento, liderado por interesses financeiros internacionais e pelas grandes empresas 
multinacionais, visando reduzir o poder que os Estados nacionais mantinham sobre a economia (RODRIGUES, 1997).

Assim, o liberalismo econômico gradativamente volta à cena desfigurado para atender às exigências do desenvolvimento capitalista do século $\mathrm{XX}$, agora com uma nova roupagem: o Neoliberalismo.

Como já citado anteriormente, no ano de 1947, economistas e intelectuais conservadores contrários às tendências da época marcada pela ascensão das idéias de Keynes, caracterizadas por um Estado assistencialista e intervencionista, reuniram-se para formular uma nova doutrina pretensamente universal, que se opunha às idéias do estado do bem-estar social e suas consequentes políticas econômicas.

O austríaco Friedrich August Von Hayek e o americano Milton Friedman foram os principais formuladores dessa corrente que criticava o caráter autoritário do Estado, sugerindo que seus encargos sociais e sua atuação reguladora impedia a realização plena das liberdades individuais e impossibilitava a competição que levava à prosperidade econômica. Assim, a proposta da nova corrente era o afastamento do Estado em relação às atividades econômicas, bem como a realização de inúmeras reformas institucionais que permitissem a livre competição e a livre circulação dos capitais, de forma que a única ação reguladora fosse a do mercado. A privatização de todos os setores da economia nacional, a transferência dos serviços públicos para o setor privado, a desregulamentação do sistema financeiro, entre outras, eram as propostas do neoliberalismo (LOMBARDI, SAVIANI, NASCIMENTO, 2006).

Agora então, com o fim dos "anos dourados", com os problemas econômicos advindos da crise do petróleo, o cenário estava propício para que o neoliberalismo se impusesse de forma hegemônica, como sendo a única resposta possível à solução dos problemas econômicos e sociais da crise capitalista que estava sendo enfrentada. Nessa base de crise real do estado capitalista, economistas, ideólogos e políticos passaram a rever teses anteriormente rejeitadas, como num "retorno à ortodoxia", originando assim novas teses monetaristas e neoliberais que passaram a nortear as políticas econômicas de muitas nações a partir do final da década de 70 (SOARES, 2000).

Segundo Anderson (1995), a hegemonia buscada por esses programas não foi conseguida do dia para a noite, mas a aceitação de governos de países importantes, 
considerados primeiro mundo, Margareth Thatcher, na Inglaterra, e Ronald Reagan, nos Estados Unidos, influenciaram outras nações nessa direção.

A construção de uma natureza hegemônica do projeto neoliberal se caracteriza por ter se constituído numa série de estratégias políticas econômicas e jurídicas além de outras tantas, caracterizadas por reformas ideológicas na sociedade com vistas à construção e difusão de um novo senso comum, que não só explica a crise a partir de seus diagnósticos a respeito das políticas assistencialistas, bem como propõe como única saída a ordem social criada a partir do livre-mercado.

Soares (2000) analisa que o modelo social do Neoliberalismo nas suas tentativas de resolução da crise global da economia acabou por produzir transformações estruturais que incluem situações como a informalidade no trabalho, o desemprego, o subemprego, a desproteção trabalhista, gerando uma "nova pobreza"; no entanto, para os neoliberais, essas condições não são uma manifestação de que o sistema estaria funcionando mal, seriam apenas a "contraface do funcionamento correto de um novo modelo social de acumulação" (p. 12).

Nessa análise, Soares (2000) destaca ainda que o ajuste neoliberal não se restringe apenas à natureza econômica, mas acaba por redefinir as relações sociais de outras instituições, que modificam seus parâmetros, criando uma espécie de ideologia do individualismo; em suas palavras:

Os pobres passam a ser uma nova "categoria classificatória", alvo das políticas focalizadas de assistência, mantendo sua condição de "pobre" por uma lógica coerente com o individualismo que dá sustentação ideológica a esse modelo de acumulação: no domínio do mercado existem, "naturalmente", ganhadores e perdedores, fortes e fracos, os que pertencem e os que ficam de fora (SOARES, 2000, p. 13).

Tratando dessa hegemonia alcançada pelas teorias neoliberais, Giroux (2005), afirma que o neoliberalismo tem se tornado uma das mais perversas e perigosas ideologias do século XXI, não somente por sua influência na economia global, sem comparação com políticas anteriores, mas principalmente pelo poder de penetrar em outras áreas, redefinindo a própria natureza do político e social.

A América Latina, em relação à hegemonia neoliberal, teve um papel preponderante, pois países como Chile, Argentina, Uruguai e Brasil, que estavam saindo de ditaduras 
diversas a partir da década de 70 e estavam tentando entrar num contexto de democratização, pareciam ser um campo propício para a experimentação dessas novas políticas, especialmente no que diz respeito às políticas educacionais (GENTILI, 1999).

Assim, a América Latina, como citado anteriormente, constituiu-se num verdadeiro laboratório experimental para o neoliberalismo, justamente pelo fato de estar sobrevivendo em democracias pós-ditatoriais, e na maioria das nações citadas, esses novos governos democráticos tinham o voto popular para fortalecer ainda mais as idéias neoliberais a serem implantadas (GADOTTI, 2006; GENTILI, 1999; SANTOS, 2008)

Nesta fase, portanto, a segunda metade do século XX, o neoliberalismo deixa de ser uma teoria produzida por economistas e intelectuais, para ser o único caminho de reforma econômica, política e social em grande parte do mundo capitalista, o que inclui não só as nações da América Latina, mas também as nações do primeiro mundo e até algumas da Europa oriental, conforme observa Gentili. (op. cit.)

Do quadro apresentado pelo citado autor, nos interessa especialmente o que ocorreu em termos educacionais, localizadamente na América Latina, entre essas décadas - 70 e 80 e os anos posteriores. Vamos nos fixar neste espaço e neste contexto histórico.

Ainda segundo o mesmo autor, nas décadas de 70 e 80, houve uma grande demanda para as políticas democratizadoras, pois essas nações haviam acabado de sair de períodos ditatoriais. Pouco a pouco, essas políticas democráticas foram se esvaziando, para uma institucionalização de uma democracia controlada, ou uma democracia da derrota (democracia não democrática). Gentili (1999) denomina esse período de "uma transição do nada para o nada", enfatizando que a base dessa democracia da derrota fora deixada por duas conquistas pós-ditatoriais:

a) traumatização subjetiva, com doses de terror suficientes para assegurar-se de não haver nenhuma tentativa revolucionária.

b) transformação objetiva da sociedade, onde nada mudou - baixos salários, com mão de obra reprimida, deflação.

Essas demandas democratizadoras tiveram vida muito curta, especialmente no campo educacional. Pouco a pouco esse discurso democrático foi eliminado, tornando possível a instalação de um novo discurso hegemônico: o da qualidade. A democracia na educação foi silenciada. 
Segundo Gadotti (2006), a América Latina foi uma região bastante sensível às políticas neoliberais, não só quanto à sua adoção, mas principalmente quanto à sua fixação. $\mathrm{O}$ autor declara que a educação é um campo emblemático dessa situação, especialmente nas décadas de 80 e 90 quando reformas baseadas nas filosofias globalizantes capitalistas neoliberais tiveram grande impacto na educação; não sem resistência de docentes e seus sindicatos.

Historicamente, a ofensiva neoliberal na América Latina no campo da educação, se inicia em 1970, no Chile sob o governo de Pinochet, consolidando-se e aprofundando-se nos 20 anos seguintes, em processos de reestruturação educativa com dimensões políticas, jurídicas, curriculares e pedagógicas (GADOTTI, 2006).

O Banco Mundial e o Fundo Monetário Internacional criaram e impuseram modelos curriculares e pedagógicos a vários países da região - os quais estavam pressionados por dívidas externas enormes - mediante políticas de ajuste, que tiveram impactos diferentes, devido aos diferentes contextos dos países. No entanto, as premissas nessas políticas eram as mesmas: a transformação da educação numa mercadoria, a mercantilização do conhecimento e incorporação dos mecanismos de mercado, além da desresponsabilização do Estado do dever de educar (GADOTTI, 2006).

Sobre essas políticas, Gentili (1999) assegura que houve a substituição do discurso da democratização no campo educacional pelo da qualidade, de cunho conservador, que acabou por hegemonizar o cenário latino-americano. Criou-se então uma relação de intersecção e de penetração entre os discursos do mercado econômico, dos discursos empresariais e de suas práticas, com os discursos e as práticas educacionais. As instituições agora plenamente constituídas, mercado e escola, entram numa relação de interpenetração, não só discursiva como também pragmática.

$\mathrm{Na}$ visão neoliberal, os sistemas educacionais passaram a enfrentar uma profunda crise provocada pelo próprio processo de expansão da escola, de sua universalização e extensão, instituídas nas formas da economia anterior que era assistencialista e que tinha como objetivo dar educação básica para as grandes massas, preocupando-se com quantidade em detrimento da qualidade.

Para os neoliberais, o processo de expansão da escola ocorreu de forma acelerada sem que tal crescimento tenha garantido uma distribuição eficiente dos serviços oferecidos. 
Uma dinâmica política de instalação de crise generalizada, um processo de cooptação dos novos governos, já com perfil claramente neoliberal e neoconservador, com os intelectuais da sociedade, através de contratos e financiamento internacionais que promoviam um novo poder ineditamente adquirido, foram criando as condições favoráveis também no campo educativo para o abandono dos discursos democratizantes em favor do discurso empresarial. Passou-se a discutir sobre educação como no âmbito empresarial, e a lógica produtivista e mercantil com seus critérios de medida e avaliação da qualidade, foram transpostos para a educação. Para a saída dessa visão de crise da educação, na visão neoliberal, a única forma eficaz seria adequar a educação às exigências do mercado, de forma que a escola funcionasse como uma empresa, sendo submetida à lógica da eficiência e da rentabilidade que sustentam o mundo empresarial. Segundo Gadotti (2006), as principais propostas do modelo neoliberal para a educação na América Latina baseavam-se em: “conteúdos mínimos; redução dos benefícios dos trabalhadores da educação; centralização curricular e pedagógica (garantidas pelas avaliações nacionais); descentralização das responsabilidades e municipalização do ensino fundamental; padrões mercantis de gestão" (p. 69).

Silva (1996) destaca que a retórica neoliberal determina à educação três objetivos básicos: preparar para o trabalho e para as necessidades da livre iniciativa do mercado; fazer da escola o meio de transmissão dos princípios doutrinários da ideologia dominante; tornar a escola um mercado para os produtos da indústria cultural e da tecnologia. Esse modelo retórico é resumido por uma palavra: qualidade (GENTILI, 1999; SILVA, 1996).

Há que se esclarecer sob qual perspectiva a retórica da qualidade total se insere na visão neoliberal, a saber, como uma idéia definitiva de excelência de ensino, com professores competentes e com conteúdos científicos de alto nível e com conhecimentos instrumentais; em termos de pesquisas, aquelas de ponta, capazes de gerar tecnologias competitivas, e finalmente gerar alunos aptos para ingressarem no mercado de trabalho (SILVA, 1996).

Silva declara ainda que "este padrão de qualidade pressupõe a transposição das práticas administrativas empresariais à área educacional, de modo a aproximar a organização escolar da organização da empresa privada" (op. cit. p. 21).

Corroborando essa idéia, Bueno (2003) declara que a qualidade na visão capitalista neoliberal baseia-se na transferência, para a escola, de concepções que foram a princípio 
consagradas em empresas do chamado primeiro mundo; estas, ao desenvolverem com sucesso os fundamentos da qualidade total, tornaram-se modelos para os educadores e para as instituições educacionais, os quais teriam que aprender sobre o assunto qualidade, com os "homens de negócio."

Comentando sobre a transposição da visão do mercado para a educação, Gentili (1999), acrescenta que a retórica conservadora da qualidade no campo educativo baseia-se numa idéia que ele denomina de "duplo processo de transposição". A primeira parte desse processo consistiu em justamente substituir o discurso democratizador pelo discurso mercantilista da qualidade, de forma hegemônica. A segunda parte do processo consistiu em transpor conteúdos da discussão sobre qualidade característicos do campo produtivoempresarial para o campo das políticas educacionais e para a análise dos processos pedagógicos.

Gentili (op. cit.) também acrescenta que o discurso da qualidade marca sua presença no mundo dos negócios através de cinco aspectos centrais, que posteriormente serão transpostos e aplicados no campo educacional.

O primeiro aspecto trata do fato de que a discussão sobre qualidade é antiga e sempre foi uma preocupação dos empresários ao longo da história do mercado. Mas as razões pelas quais se interessavam por ela foram se diferenciando, bem como foram mudando muito os próprios conceitos de qualidade.

Destacamos através do exemplo a seguir, como a preocupação com a qualidade não é algo novo - a primeira edição desse livro é de 1912 - ela esteve sempre presente; trata-se de um experimento feito em uma empresa de peças para bicicletas com vistas à inspeção de qualidade dos produtos; note-se ainda que a noção taylorista de inspeção transformou-se no que hoje se denomina por controle de qualidade.

Vemos o exemplo disso no livro sobre economia e produção, de Frederick W. Taylor (1912), "Princípios de Administração Científica" - no item "Verificação de peças de bicicleta". Nesse exemplo, o autor conta como o experimento foi minuciosamente conduzido entre cento e vinte operárias da maior empresa produtora de determinada peça usada para a fabricação de bicicletas nos Estados Unidos. O trabalho diário que era de dez horas e meia por dia, passou por várias etapas sucessivas de diminuição, chegando até oito horas e meia, de forma que a produtividade e a eficiência fossem garantidas através de algumas estratégias. 
Entre essas estratégias estava, por exemplo, a de excluir todas as moças que não tivessem coeficiente pessoal baixo, ou seja, que não conseguissem ter uma ação reflexa extraordinariamente rápida, pois cumpriam as tarefas mecanicamente, fato que acabou por excluir as operárias mais inteligentes, mais assíduas e mais dignas de confiança. Assim, após essa intervenção, o trabalho de cento e vinte moças foi garantido em qualidade e produtividade, com uma redução para trinta e cinco operárias, além da redução do período de trabalho. Através desse exemplo, notamos como qualidade e produtividade, sempre foram aspectos fundamentais ao longo da história do mercado.

O segundo aspecto, ainda destacado por Gentili (op. cit.), trata da necessidade empresarial de adaptar-se competitivamente às condições do mercado; ou seja, cada transformação ocorrida em termos de tecnologia, produção, gerenciamento, implica também em alguma adaptabilidade e ajuste, transformando o mercado em um ambiente em constante mutação. Esse caráter de adaptabilidade e ajuste ao mercado, segundo o autor, é profundamente negativo, por ser antidemocrático e dualizante quando se trata de políticas públicas educativas. Ainda corroborando esse aspecto de adaptação às necessidades do mercado, Silva (1996) destaca que com as novas tecnologias de informação e comunicação, "a educação escolar vai ao mercado, seja via financiamento de pesquisa, marketing cultural ou educacional" (p. 23).

O terceiro aspecto demonstra que a qualidade é tão importante na medida em que garante a produtividade, ou a incrementa, mantendo a rentabilidade ou aumentando-a; ou seja, qualidade-produtividade-rentabilidade é uma trilogia que não pode ser e nem deve ser tratada isoladamente por qualquer empresário no mundo dos negócios.

O quarto aspecto ainda acrescenta que a busca da qualidade supõe uma organização particular do processo produtivo. A qualidade supõe uma estratégia particular de organização que conduz a um tipo específico de controle, que tem variado historicamente. Estas formas de controle são sempre modalidades específicas de disciplinamento, que existem em toda a organização de trabalho. O controle disciplinador variou historicamente, mas para se garantir a qualidade, ele sempre deverá estar presente de alguma forma.

Gadotti (2006), ao comentar sobre os princípios de qualidade expostos em documento do Banco Mundial, indica a busca por uma estandardização da qualidade, da avaliação da aprendizagem, através da criação de parâmetros, como se tudo pudesse ser mensurável, numa 
concepção fordista de qualidade, reduzindo o ensino a aplicações de receitas e ao manejamento de técnicas.

E finalmente, o quinto aspecto demonstra que a qualidade é mensurável e tem um custo. No mundo dos negócios, para que a qualidade tenha significado, ela precisa ser mensurável e quantificável. Nota-se aqui, o espírito positivista que se impõe sobre qualquer tentativa de subjetividade metafísica, baseando-se na experimentação. Trata-se de atestar a qualidade através de uma questão pura e simples de observação e medição. Estão em destaque também a hegemonia e a universalização, provocadas por esse tipo de filosofia. As normas de qualidade hierarquizam empresas e produtos, classificam-nos através de critérios universalizados.

Ao exemplificar esses aspectos centrais do mundo dos negócios transpostos ao mundo educacional como a nova retórica da qualidade, Gentili (1999), refere-se a algumas políticas educacionais implantadas na América Latina no final dos anos 80 e na década de 90.

Entre esses exemplos destacamos a reforma estrutural do sistema educacional chileno iniciada a partir de 1988, que tinha por objetivo melhorar a qualidade do ensino, implantando algumas mudanças mais profundas num processo de descentralização e privatização do sistema educacional, que anteriormente eram vinculados ao governo federal. Nessa ação, os fundos públicos foram transferidos para o sistema privado através de subsídios públicos a todas as instituições educacionais, fossem elas públicas ou privadas, onde cada aluno teria um custo calculado, que seria subsidiado pelo governo. Mais tarde, houve ainda uma lei que autorizava os estabelecimentos particulares subvencionados a cobrar mensalidade de seus alunos, sem que o aumento de renda desta cobrança se traduzisse em diminuição da subvenção. Ligado a isso, a padronização avaliatória nas escolas, estabeleceu mecanismos de "livre competição" e de "livre escolha", que os "clientes" devem ter no "mercado". No entanto, o que se viu nessa reforma chilena, foi uma sociedade ainda mais brutalmente dividida e dualizada. Segundo o autor em destaque, a modernização, a qualidade foi assegurada como um privilégio de poucos, e para a maioria sobrou a miséria.

$\mathrm{Na}$ Argentina, instalou-se um sistema provincial de avaliação da qualidade da educação que consistia em estabelecer um sistema de medição através de um censo nas séries terminais da escola primária e secundária, avaliando todos os alunos que terminavam esses níveis com provas nas áreas de línguas e matemática. A partir dessas medições, foram 
elaborados rankings de escolas (privadas, públicas, urbanas, rurais e urbano-marginais); o conceito que embasava essas avaliações era o de que a qualidade é uma variante que se mede e que medi-la, leva à melhoria das escolas; além disso, que a difusão desses resultados melhora a qualidade, pois ocasiona uma busca por superação e mérito próprio.

Dentre os cinco aspectos do mercado transpostos para a educação, citados por Gentili (op. cit.), parece ser o aspecto da avaliação e medição, aquele que mais demonstra a filosofia mercantilista que subjaz às ações de transposição do mercado para a educação, pois em seu escopo, englobam-se todos os outros aspectos anteriormente citados, desde a preocupação com a produtividade, as modificações de acordo com as ondas do mercado, bem com um fator de controle disciplinador que a avaliação exerce sobre os avaliados.

No caso do Brasil, as políticas educacionais, desde há muito tempo mantiveram órgãos que pudessem estabelecer algum tipo de sistema de avaliação. Dentre esses órgãos temos o MEC, Ministério da Educação e Cultura, e o INEP, denominado inicialmente de Instituto Nacional de Estudos Pedagógicos que, criado em 1937 tinha como principal função, a pesquisa para orientar a formulação de políticas públicas (GHIRALDELLI, 2003). Pouco tempo depois, o INEP passou a ser órgão de assessoramento do Ministério da Educação e Saúde, e realizou importantes pesquisas a respeito da diversificação cultural das regiões brasileiras e da distribuição de recursos federais aos Estados. Na década de 50, continuou a fazer levantamentos sobre as condições de ensino em cada uma das unidades federativas. $\mathrm{Na}$ década de 80, o órgão continuou sua atuação relacionada ao fomento de pesquisas e continuou a dar suporte à secretarias do MEC na avaliação da realidade educacional do país e na disseminação das informações produzidas a partir desses dados. Atualmente, além de participação nas políticas de apoio a pesquisas educacionais, atribui-se ao INEP as responsabilidades técnicas e operacionais para a implantação de um sistema nacional de avaliação da educação básica - o SAEB - que estava até então, a cargo da Secretaria Nacional de Educação Básica (Inep: http://www.inep.gov.br/).

Entre outros exemplos, vemos basicamente a criação de três grandes exames nacionais de avaliação educacional: o SAEB, o Enem e o Provão, os quais destacamos. O SAEB, anteriormente citado, desde 1990, vem se desenvolvendo por intermédio de exames aplicados a grupos de escolas e alunos e, desde 2005, passou a ser composto por dois processos: um de avaliação Nacional da Educação Básica (ANEB), realizada nas Redes de Ensino em cada unidade da Federação, com foco nas gestões dos sistemas educacionais, e a Avaliação 
Nacional do Rendimento Escolar (ANRESC), sendo mais detalhada que a anterior com foco em cada unidade escolar, a qual recebeu o nome de Prova Brasil em suas divulgações.

Já o Enem, o sistema de avaliação do Ensino Médio, tem como principal objetivo avaliar o desempenho do aluno ao término da escolaridade básica, que recebendo as informações de forma sigilosa poderá fazer uma auto-avaliação, ver suas chances no mercado de trabalho e reordenar sua vida, segundo Ghiraldelli (2003). O citado autor sugere que essa avaliação seria sem fins de ranqueamento. No entanto, parece-me que se pais, professores e escolas, a partir do exame, podem avaliar posturas, escolas e planejamento, bem como servirse do mesmo como parte do processo seletivo em muitas instituições de ensino superior e, ainda, possibilitando a participação em programas governamentais de acesso ao ensino superior como o PROUNI, certamente pode-se considerar seu aspecto avaliativo e de ranqueamento.

Finalmente, consideramos o Provão, o Exame Nacional de Cursos, que desde o seu início foi deliberadamente criado para ser um mecanismo do governo de avaliação do ensino superior. Esse exame é realizado pelo INEP com a participação de membros da comunidade acadêmica. Todos os alunos que estão concluindo os cursos de graduação nas instituições que participam do Provão precisam fazer a prova para receber o diploma. Existe uma Comissão de Curso que define os objetivos específicos do exame para cada área, o perfil desejado do graduando, as habilidades e os conteúdos a serem desenvolvidos durante o curso bem como o formato da prova a ser aplicada. Essas Comissões recebem do INEP/MEC sugestões de conteúdos e habilidades, perfil do profissional a ser formado, enviado pelos coordenadores de cursos de variadas instituições. Através dessas informações, as Comissões definem toda a elaboração das provas bem como o critério de avaliação dos resultados que será aplicado. Segundo o próprio órgão avaliador, o objetivo do Provão é verificar a qualidade do curso e não o desempenho individual do estudante. No entanto, esse mesmo órgão declara que munido de seu boletim individual de desempenho, normalmente recebido pelo correio, o aluno poderá usá-lo como uma credencial no mercado de trabalho, além de situar o seu próprio desempenho em relação a cada grupo que participou da prova. Outro objetivo do Provão, ainda segundo os próprios avaliadores, seria fornecer informações fundamentais para que cada instituição possa desenvolver ações que melhorem a qualidade de seus cursos. Portanto, nota-se que esse mecanismo efetivamente cria um ranking entre as instituições públicas ou particulares que dele participam. 
Assim, não faltariam exemplos brasileiros de siglas e mais siglas que em caráter federal, estadual ou municipal, somam-se à tarefa de avaliar a qualidade da educação.

Um exemplo dos mais atuais, que entrou em vigor enquanto este capítulo era escrito, foi o Idesp (Índice de Desenvolvimento da Educação do Estado de São Paulo), que faz parte do Programa de Qualidade da Escola, da Secretaria da Educação do Estado de São Paulo, que tem como objetivo promover a melhoria da qualidade do ensino Fundamental e Médio da rede estadual paulista, bem como de manter a equidade do sistema. Os critérios de avaliação são o desempenho dos alunos em exames já constituídos (Saresp, Prova São Paulo, Prova Brasil) e o fluxo escolar. Há uma meta por escola que precisa ser alcançada, estabelecida pelo órgão, que segundo os idealizadores, serve como um guia para que os professores, gestores escolares, pais de alunos e a comunidade possam acompanhar a evolução das escolas no aprimoramento da qualidade de ensino. A partir dessas metas, há uma distribuição de bônus em dinheiro equivalente à evolução da escola. Se as metas foram 100\% alcançadas, todos os funcionários da escola receberão o total do bônus: $2 \%$ dos doze salários mensais, ou seja, 2,4 salários mensais a mais; e assim sucessivamente, relacionando a obtenção das metas com sua relação em valores pagos pelo bônus. Além disso, funcionários técnicos e administrativos que fazem parte da mesma secretaria da escola avaliada, ainda que não estejam ligados à escola, também receberão os mesmos valores de bonificação de desempenho.

Em entrevista recente promovida pelo movimento Educar para Crescer, o atual prefeito de São Paulo, Gilberto Kassab, afirmou ser a favor da bonificação individual, dizendo que implantará em 2010 a avaliação por mérito também na rede municipal.

(http://educacao.uol.com.br/ultnot/2009/03/30/ult105u7807.jhtm)

A repercussão dessas avaliações não apresenta consenso. Os sindicatos dos professores desaprovam esse sistema alegando principalmente dois fatores: primeiramente que as condições das instituições são muito distintas, pois a verba recebida, o número de alunos por sala e a infra-estrutura são diferentes, privilegiando aquelas que já têm melhores condições; além disso, novamente transfere-se a responsabilidade da qualidade do ensino para apenas um ator, o professor. (Sindicato dos Professores do Ensino Oficial do Estado de São Paulo em http://educacao.uol.com.br/ultnot/2009/03/30/ult105u7807.jhtm) 
Ressaltamos aqui, que na perspectiva neoliberal, a formação e a atuação dos sindicatos é vista como uma barreira intransponível para a possibilidade de desenvolvimento dos mecanismos de competição individual que garantem o progresso social (GENTILI, 1999).

O neoliberalismo, já na formação de suas bases, conforme Hayek e seus companheiros afirmavam, via as raízes da crise econômica localizadas no poder "excessivo e nefasto" dos sindicatos, e também, nos movimentos operários que corroíam as bases de acumulação capitalista, através de reivindicações salariais e através de pressões "parasitárias" para que o Estado gastasse mais com ações sociais (ANDERSON, 1995).

Destacando o outro fator da desaprovação dos sindicatos de professores a esse sistema de avaliação - a transferência da responsabilidade da qualidade para o professor - vemos ser essa percepção aquela que se encaixa perfeitamente aos conceitos neoliberais da visão de mercado onde o mérito e o esforço individuais é que garantem a qualidade e o consequente sucesso. Gadotti (2006) também corrobora essa posição, ao afirmar que na visão neoliberal, debita-se aos professores o problema de má qualidade na educação, sempre apelando para o indivíduo docente e nunca para o coletivo (sindicatos). Na afirmação de Gentili vemos que

a lógica competitiva promovida por um sistema de prêmios e castigos com base em tais critérios meritocráticos cria as condições culturais que facilitam uma profunda mudança institucional voltada para a configuração de um verdadeiro mercado educacional (GENTILI, 1997).

A paixão neoliberal por esses sistemas de avaliação explica-se pela possibilidade de competitividade, de flexibilização da oferta e da livre escolha dos consumidores, bases do mercado, que os mesmos garantem.

Mais do que uma metáfora bastante adequada, porque muitas vezes foi tomada como modelo, está o uso eficaz de um sistema de incentivos da conhecidíssima rede multinacional de uma rede de fast food - o McDonald's.

Gentili (1997) ressalta criticamente,

Os prêmios à produtividade são tal como no McDonald's, tanto meramente simbólicos (quadro de honra, empregado do mês), quanto materiais (aumento de salário, prêmio em espécie, promoção de categoria). A educação deve ser pensada como um grande campeonato. Nela, os triunfadores sabem que o primeiro desafio é assumirem-se como ganhadores. "você pertence à equipe dos campeões!", costuma 
repetir o orgulhoso Ray Kroe em suas habituais arengas à sua tropa de despachantes de hambúrgueres e batatas fritas baratas. Espírito de luta, auto-superação, confiança no valor do mérito, certeza de saber que quem está do nosso lado só atrapalha nosso caminho ao sucesso (p. 47).

Gentili (op. cit.), ainda utilizando a metáfora da mcdonaldização da educação, cita outras duas comparações para compreendermos melhor como as escolas estão inseridas num complexo mercado educacional - a formação de currículos e de professores e as diferentes formas de terceirização (pedagógica e não-pedagógica) praticadas no contexto escolar.

Sobre a formação dos currículos, podemos destacar a tentativa de uniformizar a educação, por parte das autoridades, com a criação de leis que pretendem garantir um conhecimento básico e igualitário para a população.

No Brasil, em se tratando de leis, conforme ressalta Ghiraldelli (2003), na elaboração da Constituição de 1988, houve uma grande preocupação com referência à educação. Nessa época, a onda do neoliberalismo ainda não tinha tanta força por aqui; no entanto, já em 1990 quando começaram a ser desenvolvidas as lutas pela construção de leis específicas da educação, o neoliberalismo já havia se tornado muito popular tanto na sociedade brasileira quanto no Congresso. E assim, a partir de 1996 foram formuladas as Leis de Diretrizes e Bases e, posteriormente houve a criação dos Parâmetros Curriculares Nacionais, visando garantir uma melhor aplicabilidade dessas leis.

Os PCNs, elaborados por equipes de experts pedagógicos reunidos a pedido do governo federal, se autointitulam como sendo referências de qualidade para o ensino fundamental e médio com o objetivo de propiciar a reelaboração de currículos, que tenham como meta um projeto pedagógico que foque a cidadania do aluno e a qualidade do ensino. Embora em seu próprio escopo os PCNs garantam a possibilidade de interpretação e adequação regionais, dada a continentalidade do país, contraditoriamente, apresentam o que se quer ensinar, como ensinar e para que ensinar (PCN - 1998/ introdução).

Cremos que essa contradição tem a ver com estruturas epistemológicas da educação, sendo que esta, inserida num momento pós-moderno com tendências de mudanças epistemológicas e estruturais, ela mesma estaria passando por profundas mudanças em termos de propósitos, conteúdos e métodos, mudanças as quais, também são aspectos das incertezas da pós-modernidade. 
Sobre isso, Usher e Edwards (1994), comentam que os debates a respeito de currículos, da pedagogia e da organização da educação estão em harmonia com as mudanças do período pós-moderno, mas muitas vezes, sem a real reflexão de como seria essa posição de pós-modernidade. Disso resultam muitas práticas e conceitos "atualizados" incorporados nos currículos pós-modernos, sem, no entanto, resultar em uma verdadeira reconstrução do currículo. Assim, se na pós-modernidade não há uniformidade, um discurso de educação pósmoderno não pode ser unificado. Usher e Edwards (op. cit.) falam em um chacoalhar de fundamentos que questione certezas e garantias das teorias e das práticas educacionais, através de um exame crítico, que possa oferecer respostas locais e contextualizadas, como vemos:

Sendo a perspectiva pós-moderna, ela mesma, questionadora, tem que prover pelo menos um discurso alternativo (um jeito diferente de falar, pensar e agir) que possa ser apropriado para um exame crítico da teoria e da prática da educação (p. 25 e 26$)^{3}$.

Como citado acima, outra comparação de Gentili (1997), para exemplificar a inserção da educação no contexto mercadológico, utilizando ainda a metáfora da mcdonaldização da educação, trata especificamente do objeto de estudos desta pesquisa, a saber, a terceirização praticada no contexto escolar.

Gadotti (2006) também afirma que orientadas por essa visão de qualidade, onde o docente seria um problema em relação à qualidade de ensino, na perspectiva neoliberal, as buscas de alternativas passam pela terceirização, contratando trabalhadores temporários, docentes não formados, assegurando que seu conhecimento científico-pedagógico é inútil, pois o que precisam fazer é saber aplicar as "receitas", os programas instrucionais (p. 65).

Há mais de três décadas, a terceirização tem ocorrido nos meios empresariais, segundo Amato Neto (1995), por conta de sucessivas crises econômicas e consequentes reorganizações nos padrões de concorrência, que acabaram levando as empresas a importantes reestruturações organizacionais. A terceirização tem como objetivo a redução de custos e a melhoria da qualidade e dos resultados; esses objetivos são conseguidos através da

\footnotetext{
3 Tradução da pesquisadora para: Since a postmodern perspective is itself a questioning one, it does at very least provide an alternative discourse (a different way of speaking, thinking and acting) which can be appropriated for a critical examination of the theory and practice of education. (p. 25 e 26)
} 
focalização, ou seja, a dispensa de atividades que não sejam atividades-fim, sendo estas delegadas para contratados especializados naquele determinado serviço. Possibilita-se assim, a aplicação de controles rígidos de qualidade, garante-se uma alta produtividade com redução de custos, gerando um aumento da rentabilidade.

Dentro de uma perspectiva neoliberal no campo educacional, esse fenômeno tem ocorrido em relação a atividades não pedagógicas, relacionado a serviços administrativos, tecnológicos, de manutenção em geral. Nosso interesse, no entanto, será a ocorrência desse fenômeno na área pedagógica, especificamente em relação ao ensino e aprendizagem de língua estrangeira.

A seguir, apresentaremos os pressupostos dessas práticas de terceirização em nível educacional e como esse fenômeno tem se apresentado como uma provável "solução" para o "problema" do ensino de língua estrangeira, na visão de algumas escolas, bem como a visão mercantilista imposta pelos terceirizadores, no caso, os institutos de idiomas.

\subsection{Pressupostos da terceirização}

A proliferação de cursos de idiomas particulares, o fenômeno das parcerias de escolas com institutos de idiomas em esquemas de terceirização, são evidências claras de que, embora o conhecimento de línguas estrangeiras seja altamente prestigiado na sociedade brasileira, como disciplinas escolares, são vistas deslocadas do processo educativo escolar. Essa questão será retomada mais adiante.

Vale ressaltar que a concepção de escola a que nos referimos aqui, é a de um espaço social, econômico e cultural, que não é neutro, logo, está ligado às questões de poder e controle, conforme criticamente ressaltado por Giroux (1997), sendo o oposto do que convencionalmente é idealizado por boa parte da sociedade: como um local neutro, que apenas repassa valores e conhecimentos de maneira objetiva. Essa tendência advém do ideário positivista de educação. Segundo esses ideais, a instituição escolar seria um espaço neutro com a função de difundir um conhecimento único, racional e objetivo, ao qual, todos deveriam ter acesso. A essa instituição caberia garantir igualdade de oportunidades, através da competição e da meritocracia, para que em condições iguais, a partir de dons e aptidões 
pessoais, os indivíduos tivessem a possibilidade de ascensão na hierarquia social (NOGUEIRA e NOGUEIRA, 2006). Contrariamente a isso, conforme Giroux (1997), as escolas são "lugares que representam formas de conhecimento, práticas de linguagem, relações e valores sociais que são seleções e exclusões particulares de vida social" (p.270). Portanto, desempenham um papel de política e de poder, capazes de incorporar, expressar e regular formas de autoridade, tipos de conhecimento, valores morais e interpretações do passado e futuro. Ademais, questões como a construção de identidades e relações de poder estão intimamente ligadas ao ensino de línguas estrangeiras, nosso foco de pesquisa.

É válido ressaltar que a terceirização como um fenômeno mercantil, vem acontecendo como uma tendência crescente nos meios empresariais há mais de três décadas. Segundo Amato Neto (1995), em artigo publicado em revista administrativa especializada, as crises econômicas mundiais e consequentes reorganizações nos padrões de concorrência intercapitalista acabaram impondo às grandes empresas uma reestruturação organizacional. Em linhas gerais, essa reorganização seria baseada na idéia de uma produção enxuta, nas filosofias de qualidade total e de produção just-in-time. Passou-se a adotar uma estratégia de descentralização produtiva, com concentração no negócio central (core business) e subcontratando várias outras empresas (terceiros), especializadas em serviços de apoio, produção ou fornecimento dos produtos finais. Esse movimento de descentralização produtiva gerou tendências conhecidas como focalização, terceirização, horizontalização, parcerias, etc. Anteriormente, o tipo de estrutura organizacional seguido pelas grandes empresas, era o baseado no paradigma de produção em massa (fordismo americano), que seguia entre outros princípios, a estratégia de integração vertical das empresas, reunindo numa mesma unidade, o máximo possível de atividades - produtivas ou de apoio. A partir do pós-guerra, nos Estados Unidos, e especialmente nos anos 70, a indústria japonesa surgiu como uma nova potência industrial, trazendo profundas mudanças nas tradicionais formas de organização, bem como na produção.

Essa tendência de descentralização produtiva / administrativa das grandes empresas acabou por inaugurar conceitos importantes de desintegração vertical, terceirização, focalização e subcontratação, os quais baseiam-se em alguns princípios importantes, entre os quais ressaltamos o foco no produto final que deve ser mantido pela restrição de processos, tendo em vista manter a "excelência" na qualidade dos produtos, e também, o fato de que só devem ser mantidas pela empresa aquelas atividades para as quais ela mantenha uma real 
competência competitiva dentro do mercado. A empresa moderna deveria, assim, focalizar esforços nas atividades (core business) que realmente pudessem trazer vantagens competitivas para si, limitando as atividades, reduzindo o número de processo, enxugando suas estruturas administrativas e delegando a uma rede de outras empresas as funções que pudessem ser consideradas como complementares ou acessórias. Terceirização, portanto,

refere-se ao ato de transferir a responsabilidade por um determinado serviço ou operação de uma empresa para outra(s), neste caso conhecida(s) como terceira(s). Nesta forma, a empresa contratante deixa de realizar algumas ou várias atividades com seus próprios recursos (pessoal, instalações, equipamentos, etc.) e passa-a(s) para a(s) empresa(s) contratada(s) (AMATO NETO, 1995, p.38).

Na economia capitalista, o processo de terceirização tornou-se uma tendência mundial associada ao interesse de se determinar claramente o foco de atuação das empresas, de modo a se desvencilharem de atividades que não constituem suas atividades-fim, através da focalização. Com isso, seria possível reduzir os custos e melhorar a qualidade dos resultados, já que os fornecedores contratados seriam empresas especializadas e inovadoras nessas atividades (AMATO NETO, 1995).

Ao transpormos esse pensamento para o campo educacional, especificamente para o ensino de língua estrangeira, notamos que se considerarmos que educar seja a atividade-fim da escola, a língua estrangeira, nessa perspectiva, não seria vista com essa característica, ou seja, estaria ausente da proposta de formação educacional do cidadão como um todo, colocando o ensino de língua novamente sob uma visão tecnicista e voltada para a profissionalização, reiterando-se a idéia de realimentação do mercado produtivo vigente. Trata-se, portanto, de uma descaracterização dos objetivos educacionais do ensino de língua estrangeira.

Sobre esse fenômeno especificamente no meio escolar, Cordaro e Barão (2009), em site de consultoria educacional, comentam que a terceirização de atividades-meio (cantina, limpeza, transporte etc.) é bastante interessante do ponto de vista produtivo e não costuma despertar problemas ou discussões mais acaloradas, mas de acordo com os autores, o mesmo não acontece quando a terceirização é a atividade-fim, no caso da escola, a educação em si. Segundo suas análises, uma escola não poderia praticar essa política de forma generalista, pois perderia o controle sobre a qualidade de seus serviços. No entanto, no caso da terceirização do ensino de línguas, a análise muda totalmente de figura, pois, juntando-se a 
necessidade do conhecimento da língua inglesa como uma exigência básica do mercado de trabalho, com a deficiência de grande número das escolas formais no ensino de línguas por seus recursos próprios, há cerca de dez anos, iniciou-se um movimento, primeiramente entre as escolas particulares, no sentido da busca de parcerias com escolas de idiomas. Em pesquisa sobre a busca de soluções para essa deficiência no ensino de língua estrangeira das escolas formais, Uechi (2006) aponta em seu estudo que, entre possibilidades de soluções para o "problema" do ensino de inglês, a terceirização destaca-se em dois formatos: na parceria entre um colégio particular de ensino fundamental e médio e uma escola de idiomas do mercado, de forma extracurricular, e a terceirização intracurricular, na qual a escola de idiomas assume todas as aulas de idiomas da grade curricular dentro da escola formal.

De variados formatos, essa terceirização visava atender de maneira direta aos anseios da clientela (alunos e pais) de aprender o idioma de forma fluente e eficaz, onde as escolas ajustariam suas grades horárias, cederiam seus espaços para as instituições especializadas no ensino de línguas, que fariam toda a operacionalização do processo - desde o planejamento, materiais didáticos, até o exercício do magistério em sala de aula.

Segundo os consultores, existem muitos benefícios práticos observáveis na parceria, assim como algumas limitações. Entre as limitações destacam-se a dificuldade em compatibilizar metodologias; dificuldade em manter a disciplina em sala de aula; diferenças no modelo de avaliação; entrosamento entre equipes.

Os benefícios seriam: metodologia especializada - aprender com quem tem know-how garantido, um especialista; nivelamento de alunos - para garantir menor disparidade de conhecimentos prévios, visando um rendimento maior; marca - uma garantia de diferencial de marketing. No mundo competitivo em que a educação se tornou, esses são benefícios nada desprezíveis, porque segundo os mesmos consultores, a escola alia qualidade com um poderoso diferencial de discurso para a clientela. A educação passa a ser um bem de consumo, alunos e pais tornam-se clientes e o professor, em um gerente educador, um "mero agente de venda", para estudiosos do assunto. Bueno (2003) analisa ainda que o aluno-cliente, na sociedade neoliberal, também será visto como mercadoria, ao ser "vendido" no mercado de trabalho. 
Observa-se assim, que a educação, especificamente no que se refere ao ensino de línguas, molda-se às características do mercado, tornando-se mais um bem de consumo na sociedade pós-moderna.

O raciocínio dos administradores educacionais ao terceirizarem o ensino de línguas nas escolas formais tem sido o de que se a língua estrangeira é inquestionavelmente um "bem" essencial para o status profissional de seus "clientes", os alunos, bem como para as necessidades de um "mercado" globalizado em expansão, nada mais óbvio do que entregar essa tarefa para quem entende do "negócio" e para quem tem tido "sucesso" em alcançar seus objetivos.

As palavras destacadas no trecho anterior nos lembram da intersecção da educação com o mercado, não apenas no campo linguístico ou simbólico, mas como evidência da cooperação e dependência dessas duas instituições que ora se movem sob uma base neoliberal.

No entanto, segundo Pennycook (2001), na aula de línguas podemos criar possibilidades e encontrar formas de trabalhar com a formação de identidades dos alunos, através das identidades referenciais e das posições de sujeito as quais dispomos em nossas aulas. Portanto, cremos que o ensino de línguas, assim como o de outras disciplinas, seja função e responsabilidade da escola, com as características e conceitos que permeiam a mesma.

Não há dúvida que deve haver pontos de intersecção e cooperação entre essas duas instituições; contudo sob a retórica da qualidade no campo educacional, a educação subordina-se ao mercado e converte-se em mais um instrumento de dualização e polarização social, características do projeto neoliberal, conforme ressaltado por Gentili (1999).

Corroborando essa idéia, Giroux (2005) declara que "o capitalismo exerce a dupla tarefa de usar a educação tanto para treinar trabalhadores para o setor de serviços, quanto para produzir consumidores por toda a vida."

Do outro lado da moeda, a partir da perspectiva das escolas de idiomas, em entrevista no jornal eletrônico Valor Econômico (maio/2008), é destacado o fato de que as escolas de idiomas, com esse novo formato de negócio, não precisam mais esperar que seus clientes venham bater em suas portas, pois com a terceirização, angariam um número expressivo de 
clientes num mesmo espaço, com custos muito reduzidos, visto utilizarem as dependências da própria escola.

Na citada reportagem são descritas as histórias de sucesso com a terceirização de cinco escolas de idiomas brasileiras; a escola 1 está dentro de quarenta e sete colégios da Grande São Paulo, com um volume que representa $15 \%$ do total de estudantes que possui em suas dezessete unidades próprias e colégios; a escola 2, assumiu a grade curricular de dez colégios, que representam $10 \%$ do faturamento; a escola 3, atende cerca de dois mil alunos, em dez colégios; a escola 4 tem planos de nos próximos cinco anos, estar em cem colégios de diversas cidades do país; e finalmente, a escola 5, está presente em quase cinquenta colégios, atendendo um total de dez mil alunos.

De acordo com a perspectiva neoliberal, não parece haver dúvida de que a terceirização do ensino de idiomas transformou-se num sucesso de mercado. A lógica do lucro e da eficiência que permeia as administrações neoliberais passa a ser a mesma nesse contexto de terceirização do trabalho educacional. Para os neoliberais, uma educação de qualidade está vinculada às necessidades do mundo moderno; assim sendo, as instituições escolares devem funcionar como produtoras de serviços educacionais.

Não seria por isso, que deveríamos supor que qualidade não seja algo que se deva reivindicar nos setores que lutam pela transformação da educação pública e da educação em geral. Diferentemente, a proposta seria construir um novo critério não hegemônico e não universal para o conceito de qualidade, atribuindo-se historicidade, contexto local e político à essa discussão. Parte-se do pressuposto que essa qualidade total nos moldes mercantilistas, não seria o meio para a formação de seres humanos emancipados, que respeitam diferenças e convivem com elas.

Há também o duplo desafio de se destruir essa retórica dualizante, que tornou-se senso comum, e de se construir um novo sentido de qualidade como direito de todo cidadão. A idéia da busca da excelência parte, explícita ou implicitamente, da aceitação de uma sociedade dual. Para uma grande maioria, qualquer educação serve, pois ela ocupará os postos de baixa qualificação, sem espaço para a iniciativa nem capacidade de decisão. Para a minoria, os que se sobressaem, há a exigência do melhor, pois eles tomarão as decisões pelos outros.

O livre mercado, ideal neoliberal, mais do que qualquer ideal democrático, é a força diretriz da economia e das políticas mundiais. Sua lógica, como ressalta Giroux (2005), 
insinua-se dentro de cada relação social - relações entre pais e filhos, médicos e pacientes, professores e estudantes, todos reduzidos à fornecedores e clientes, nas palavras do citado autor.

\subsection{Os conflitos da terceirização}

Conforme alegam as escolas mencionadas anteriormente, uma das importantes razões para a procura das parcerias ou terceirizações como solução para o fracasso do ensino de língua estrangeira nas escolas formais, é a busca pela qualidade, um ensino efetivo de língua estrangeira, especialmente no que diz respeito aos aspectos linguísticos e estruturais da língua.

Os que postulam a melhoria do ensino de língua estrangeira nas escolas formais através da prática de terceirização por escolas de idiomas fazem-no baseando-se na retórica da educação com qualidade, não levando em conta os aspectos ideológicos e políticos que subjazem a esses discursos que longe de serem apenas simbólicos ou terminológicos, indicam uma prática política e social concreta. Não omitimos com isso a necessidade da qualidade no ensino de língua estrangeira, mas trata-se de, nas palavras Gentili (1999), “construir um novo sentido que leve a qualidade da educação ao status de direito inalienável que corresponde à cidadania, sem nenhum tipo de restrição ou segmentação de caráter mercantil” (p. 172).

Assim, percebemos que possa haver um conflito no que seria, em princípio, o conceito de qualidade na visão educacional e o conceito de qualidade numa visão empresarial.

Segundo Gentili (1999), essas questões tipicamente do mercado e do mundo empresarial começaram a ser transpostas para o mundo educacional a partir do final da década de 80 , sob o discurso velado da qualidade e da excelência. Segundo ele, os discursos hegemônicos sobre qualidade que fazem parte do campo empresarial, imprimiram um claro sentido mercantil de consequências dualizadoras e anti-democráticas nos discursos educacionais. O mesmo autor reforça ainda que a retórica da qualidade substituiu o discurso anterior da educação democratizante - não só nos meios intelectuais - mas principalmente e dramaticamente entre aqueles que "sofreram e sofrem as consequências do êxito destas políticas conservadoras: os professores, os pais e os alunos" (op. cit. p.115 e 116). 
Comentando aspectos do Neoliberalismo, cenário social do fenômeno em questão, o autor supracitado apresenta ainda algumas considerações sobre como a dinâmica política contribuiu para criar as condições favoráveis a um progressivo abandono dos discursos democratizadores no campo educativo. Houve um processo de transposição, onde a qualidade e a educação passaram a ser como na lógica produtivista mercantil, como no âmbito empresarial. Este processo, longe de "expressar a satisfação das demandas populares por educação, tem sido a expressão de um progressivo abandono das expectativas de ação democratizante nas políticas do setor" (op. cit. p.126).

Essa seria uma visão neoliberal, filosofia que permeia essas transformações, onde uma educação de qualidade está vinculada às necessidades do mundo moderno; assim sendo, as instituições escolares devem funcionar como produtoras de serviços educacionais.

Observa-se assim, que a educação em algumas instâncias institucionais, sucumbe às características do mercado, tornando-se um bem mercadológico em nossa sociedade pósmoderna, ocorrendo o mesmo com o ensino de línguas. Sendo a língua estrangeira, inquestionavelmente, um bem essencial para o status profissional, bem como para as necessidades de um mercado em expansão globalizada, nada mais óbvio do que "entregar" essa tarefa, para quem entende do "negócio" e também para quem tem tido "sucesso" em alcançar seus objetivos. Infere-se que o raciocínio dos administradores educacionais ao terceirizarem o ensino de línguas das escolas de educação formal apresenta a seguinte lógica: se os empresários dos institutos de idiomas souberam desenvolver com êxito o ensino de línguas em suas instituições, farão o mesmo pela melhoria da qualidade do ensino de línguas nas escolas de educação formal. Infere-se também, que a lógica do lucro e da eficiência que permeia as administrações neoliberais passa a ser a mesma nesse contexto de terceirização do trabalho educacional.

\subsubsection{A influência da publicidade no contexto escolar: disseminação da terceirização do ensino de idiomas através da mídia.}

Considerando que a publicidade se caracteriza pelo uso de variadas mídias na disseminação de valores especificamente mercadológicos com o objetivo de implementar vendas ou implantar produtos, interpretamos como conflituosa a relação dos espaços 
midiáticos que se utilizam dessas concepções, para expor e praticar a disseminação de "produtos educacionais", que a priori deveriam ser naturalmente e democraticamente oferecidos a todos no espaço escolar, pela educação formal.

Além disso, as propagandas dos institutos de idiomas ressaltam justamente o item qualidade como uma das importantes justificativas para a busca de uma solução ao fracasso do ensino de língua estrangeira, através da terceirização do ensino de línguas dentro das escolas formais.

Desta forma, as propagandas dos institutos de idiomas que oferecem serviços de terceirização de ensino de línguas estrangeiras no formato intracurricular, as quais estão disponibilizadas em sites institucionais na internet, foram também consideradas nesta pesquisa como um instrumento para análise, a partir da interpretação do seu conteúdo textual.

O referido material que constitui o corpus desta parte da pesquisa, já integra a decisão de escolha sobre as propriedades textuais que se pretende analisar. Segundo Orlandi (1999), a análise é um processo que começa pelo próprio estabelecimento do corpus e que se organiza face à natureza do material. $\mathrm{O}$ fato de as propagandas escolhidas estarem dispostas em uma mídia da nova tecnologia como a Internet, também produzirá um efeito diferenciado do que se as mesmas estivessem dispostas em produção textual do tipo panfletos, por exemplo. Além de distribuição diferenciada, pois as propagandas da Internet, a priori, têm a possibilidade de atingir um número muito mais expressivo de pessoas do que a panfletagem, o modo de abordagem, com as informações dispostas em um site terão também um tipo diferenciado de leitura, bem como atingirão um determinado público alvo. Cada detalhe de produção, design, etc, e a escolha da própria mídia, têm também o seu objetivo específico abrindo possibilidades determinadas de produção de sentidos. Citando Kress (2004): “Todos os tipos de mídia oferecem possibilidades específicas para o seu designer bem como para o seu leitor/usuário em sua leitura/utilização específicas."

Vale ressaltar que embora essa análise se concentre nos aspectos textuais, a mídia utilizada, o design, as imagens, também têm sua leitura e interpretação na produção de sentidos, que embora sejam consideradas, não serão privilegiadas.

Ressaltamos nesse ponto, o papel fundamental das diferentes mídias que contribuem para que a sociedade atual desenvolva e dissemine seus valores e ideologias de forma contundente, hegemônica e também velada. 
Como comentado anteriormente, a hegemonia do discurso neoliberal, bem como a penetração social desse discurso, não foi produto do acaso nem apenas uma questão decorrente da contingência histórica; muitos fatores históricos, sociais e políticos contribuíram para que com o passar do tempo, o neoliberalismo se transformasse numa verdadeira alternativa de poder no interior das principais potências do mundo, que também seriam assimiladas e imitadas por outros países ainda em desenvolvimento.

Não podemos esquecer o importante e decisivo papel da mídia com sua contribuição tanto na construção dessa ideologia, como em sua disseminação na sociedade. Nesse contexto, podemos atribuir à mídia, uma função tanto formadora e reprodutora da ideologia quanto controladora, como vemos na seguinte citação de Fairclough (1995):

Textos da mídia têm efetivamente uma função ideológica no controle e na reprodução social; mas eles também operam como "commodities" culturais em um mercado competitivo, são parte dos negócios de entretenimento, são idealizados para manter as pessoas politicamente e socialmente informadas, são artefatos culturais em si próprios, por aspectos estéticos particulares; e eles estão ao mesmo tempo envolvidos - refletindo e contribuindo - com a mudança de valores culturais e identidades (p. 47 e 48$)^{4}$.

Ainda sob essa perspectiva, vemos não só a formação e a reprodução de uma ideologia através do discurso da mídia, mas também e ao mesmo tempo, a concepção de um sujeito, pois só é possível conceber o discurso a partir do sujeito, conforme nos pressupostos da análise do discurso. O indivíduo é interpelado ideologicamente em sujeito e identifica-se imaginariamente com a "forma-sujeito", conforme concebida por Pêcheux, -"entendida aqui como domínio de saber constituído de enunciados discursivos, que representam um modo de relacionar-se com a ideologia vigente, regulando o que pode ser dito, mas também o que não pode, não deve ser dito.” (INDURSKY, 1998, p.115). Assim, o sujeito é percebido a partir de lugares socialmente determinados e, sendo ele social, perde suas características individualizadoras. É desse sujeito que tratamos na instância do discurso.

\footnotetext{
4 Tradução da pesquisadora para: Media texts do indeed function ideologically in social control and social reproduction; but they also operate as cultural commodities in a competitive market, are part of the business of entertaining people, are designed to keep people politically and socially informed, are cultural artefacts in their own right, informed by particular aesthetics; and they are at the same time caught up in - reflecting and contributing to - shifting cultural values and identities (p. 47 e 48).
} 
Vale salientar que a ideologia produzida e reproduzida pela mídia, que interpela e assujeita os indivíduos, não é aquela determinada apenas e tão somente pelos aparelhos do Estado segundo concepções marxistas, mas também todas as construções imaginárias de valores e de "verdades" que permeiam todas as relações sociais. Assim, a noção de sujeito e ideologia está intrinsecamente relacionada, pois só existe a prática dos sujeitos através e sob uma ideologia, bem como só existe uma ideologia através dos sujeitos e para os sujeitos. Portanto, a ideologia interpela os indivíduos em sujeitos, que agem sob um pano de fundo ideológico. Sob essa perspectiva de sujeito e ideologia e considerando o importante papel da mídia tanto na produção quanto na reprodução dessa ideologia, é que faremos essa análise das propagandas das escolas de idiomas ao oferecerem os seus serviços de ensino de língua terceirizado às instituições de educação formal.

Como já citado anteriormente, o corpus (apêndice p. 171-176) para a análise compõese de excertos dos textos de propagandas dispostas nos sites institucionais de quatro escolas de idiomas bastante conhecidas no mercado brasileiro, as quais estão dispostas no anexo. Os nomes das instituições foram substituídos por pseudônimos, respectivamente: E1, E2, E3, E4.

Excerto 1, referente à E1:

Com E1, sua escola ganha em qualidade, alunos e rentabilidade. (grifo nosso)

Nota-se aqui, a transferência do discurso empresarial tanto no aspecto linguístico, utilizando palavras tipicamente usadas do mundo dos negócios, bem como sugerindo a visão mercantilista da chamada trilogia do mercado (GENTILI, 1999): qualidade-produtividaderentabilidade (por meio da palavra "ganha"); ou seja, numa visão mercadológica, a qualidade não pode ser tratada isoladamente; só valerá a pena investir na qualidade havendo a garantia de, neste caso, o aumento do número de alunos e consequentemente um aumento da rentabilidade.

Seguindo a idéia mercantilista, a escola oferece outros recursos, todos ligados a essa mesma visão empresarial, colocados estrategicamente antes dos aspectos pedagógicos, que seriam esperados como prioridade em uma instituição educacional.

Excerto 2, referente à E1:

Diferenciais do Núcleo de Idiomas E1:

- $\quad$ Marketing 
- $\quad$ Comerciais

- $\quad$ Financeiros, Administrativos e Logísticos (grifos nossos)

- $\quad$ Pedagógicos

Salientamos, aqui, não só o uso linguístico específico do discurso empresarial sendo colocado como diferencial, bem como sua posição privilegiada e anterior aos aspectos pedagógicos.

Excerto 3, referente à E1:

- $\quad$ E1, uma marca reconhecida

- $\quad$ Selo Excelência $\mathrm{ABF}$

Ainda no mesmo exemplo, em outro excerto do texto, notamos a preocupação com o conceito de marca, tipicamente ligado aos valores empresariais, bem como a descrição desta espécie de "selo de garantia", o qual denota "excelência". Vale ressaltar que a sigla ABF, refere-se à Associação Brasileira de Franchising, que periodicamente faz um ranking das melhores empresas de franquias. Esse conceito de medição e hierarquização, aspecto notável do espírito positivista, o qual será abordado mais adiante, o qual norteia o mundo empresarial, estabelece que a qualidade só é válida se for medida por experimentação e se for quantificada.

No próximo excerto, além da utilização do discurso empresarial em termos linguísticos, podemos notar outro aspecto importante da ideologia que justificaria o ensino de idiomas na escola de educação formal: o receio do fracasso.

Excerto 4, referente à E2:

Convênio Escola - E2 - E2 EDUCA +

O programa de ensino de idiomas completo para sua escola (...) Afinal, os pais procuram as escolas mais completas, que ofereçam o maior mix de aprendizado em uma boa relação custo-benefício. (grifos nossos)

Ao sugerir essa noção de completude no trecho acima, ressaltamos aspectos da pesquisa de Uechi (2006) que diagnostica o ensino de idiomas, especialmente o Inglês, como disciplina-problema nas escolas de educação formal, com a percepção de que há uma constante busca de completude, de aprimoramento por parte das mesmas para uma renovação 
no ensino de idiomas. Segundo Uechi, tal conflito reside no fato de que as escolas buscam inovações pedagógicas que as situem como mais adequadas e eficientes às propostas educacionais contemporâneas, porém, ao mesmo tempo, parecem sofrer abalos na sustentabilidade de seus próprios projetos devido às inevitáveis influências presentes nas sociedades pós-modernas: por exemplo, a atribuição de "dominar" o idioma estrangeiro como exigência para se tornar parte do mundo globalizado e de se conseguir um bom emprego no futuro. Apresenta-se assim, a terceirização do ensino como uma das soluções para a disciplina-problema, buscando no outro - no caso, a escola de idiomas - sua completude.

\section{Excerto 5, referente à E2:}

As exigências do mercado

Em um mercado cada vez mais competitivo, como o da educação, destacam-se as instituições de ensino que oferecem mais e melhores diferenciais, através de atividades extracurriculares e cursos adicionais. Afinal, os pais procuram as escolas mais completas, que ofereçam o maior mix de aprendizado em uma boa relação custo-benefício.

Vemos aqui delimitada a sujeição da instituição educacional às "exigências" do mercado, onde o valor de troca substitui o valor de uso. Nota-se aqui a relação custobenefício e a proposta de oferecer mais e melhor reafirmando o conceito capitalista de que tudo tem um valor, um custo; se qualidade melhor é oferecida, isto terá consequentemente um custo, portanto, paga-se por ela. Negligencia-se, assim, o ensino de qualidade como um direito inalienável de todo o cidadão e a qualidade passa a ser privilégio de uma minoria que pode pagar por ela, conforme críticas de Gentili (1999).

$\mathrm{Na}$ expressão, um mercado cada vez mais competitivo, conceito do mundo empresarial, a noção de competitividade está indissoluvelmente ligada à de rentabilidade, e esta é transposta também para o campo educacional. Conclui-se que segundo essa concepção, instaura-se uma competição que se volta para a educação e cultura do mercado.

Excerto 6, referente à E2:

E2 EDUCA +

Uma grande rede de ensino.

Dois formatos de negócios. 
A certeza do sucesso.

A melhor escola de idiomas dentro da sua escola. (grifos nossos)

No excerto 6, embora a instituição se auto-denomine como rede de ensino, observa-se que, em seguida refere-se a dois formatos de negócios, no que fica implícito que há uma diferença entre uma instituição e outra, uma representando o mercado e a outra, a educação formal; a primeira oferecendo a qualidade, exigência do mercado, e a segunda, aceitando que há um fracasso implícito na educação formal, e que esta, unindo-se à primeira, poderá obter a certeza do sucesso. A noção de sucesso, para Gentili (2000), quando este compara os esquemas neoliberais para o sucesso das empresas (como na empresa McDonald’s) com a educação, percebe-se que, nesta perspectiva, quem produz mais, ganha mais e, portanto, nessa concepção, a educação pode ser pensada como um campeonato. "Espírito de luta, de auto-superação, de confiança no valor do mérito, certeza de saber que quem está ao nosso lado só atrapalha nosso caminho ao sucesso" (op. cit. p. 49).

No próximo excerto, destacamos outra menção que alude ao Neoliberalismo e ao discurso mercantilista, que Gentili aponta ser a padronização através da busca de modelos, que podem atestar sucesso para serem seguidos e imitados.

Excerto 7, referente à E3:

Para agregar valores, 19 colégios já fazem parcerias com a E3 para cursos extracurriculares e intracurriculares de Inglês. (...)

O programa mais tradicional é o E3 In - parceria de ensino extracurricular já aplicado em 18 colégios como (nomes de sete colégios de São Paulo e da grande São Paulo). (grifos nossos)

Destacamos neste trecho, que todos os colégios citados são considerados colégios destinados a uma classe privilegiada da sociedade; além disso, estão reconhecidamente entre os "top" em termos de qualidade de ensino, portanto, fica implícito nesta expressão de agregar valores, não só a linguagem empresarial de lucros, como também a não constatação do fracasso como nas propagandas anteriores, e sim, o oposto disso; portanto, busca-se o "plus", a excelência, pois se você já é bom, pode ser melhor ainda, segundo os critérios de sucesso de uma sociedade que prioriza os bens de consumo. 
Excerto 8, referente à E3:

Lançado este ano, o E3 Intracurricular é um programa pelo qual o colégio terceiriza o ensino de Inglês, delegando a disciplina à E3. (grifos nossos)

Vemos neste trecho, de forma muito explícita, os valores mercantis dados para esse novo tipo de lucratividade nas empresas, a terceirização. Para corroborar nossa análise, citamos Gentili (2000), que compara a empresa McDonald's com as instituições educacionais, por causa das tendências neoliberais assimiladas por estas. Ao comentar as frequentes formas de terceirização (pedagógica e não-pedagógica) que se apresentam na sociedade neoliberal como um programa de reforma educacional que visa maior produtividade, qualidade e sucesso, o mesmo autor faz uma comparação interessante com a produção de um Big-Mac, que mantém seu altíssimo nível de qualidade, graças às contribuições da terceirização:

A aplicação de uma série de rígidos controles de qualidade garante uma alta produtividade, além da redução dos custos de produção e, em consequência, um aumento da rentabilidade obtida por esses restaurantes. Essa racionalidade aplica-se também ao campo educacional. A lógica do lucro e da eficiência penetra as administrações neoliberais. È nesse contexto que a terceirização do trabalho educacional constitui uma forma de mcdonaldizar a própria escola (op. cit. p. 53).

Além disso, a afirmação de que se estaria delegando a disciplina à outra instituição, exime a primeira, no caso a educacional, de sua própria função e responsabilidade, a de educar através do ensino de uma língua estrangeira, seja por omissão ou por incompetência.

Verifica-se que no excerto novamente a questão da garantia de qualidade é apresentada, incorporando-se à noção de vantagem entre outros oferecimentos.

Excerto 9, referente à E4:

\begin{tabular}{|l|}
\hline Veja só quantas vantagens o E4 pode trazer para os seus alunos: \\
dinâmica e atraente como nas unidades E4. \\
Eficácia: Inglês e Espanhol com metodologia comprovadamente eficaz, \\
Economia: os mesmos cursos oferecidos nas escolas por preços bem mais \\
acessíveis e com a mesma qualidade, inclusive com emissão de certificados. \\
Qualidade: em grupos reduzidos, os alunos aprendem com professores do E4 \\
ou dápria escola, treinados e supervisionados pela equipe do E4. (grifos nossos)
\end{tabular}


A noção de "vantagem" colocada aqui como mote da propaganda, remete-nos à relação custo-benefício tão estimulada em nossa sociedade (CARMAGNANI, 2001) e ao senso de valores, onde "tudo só tem valor na medida em que se pode trocá-lo" (GIROUX, 2005, p.148), conceitos fundamentais de uma ideologia capitalista onde o mercado é livre com a finalidade de gerar competição.

No item eficácia, escolhido como o primeiro na lista de vantagens, vale ressaltar, a presença do interdiscurso ou memória discursiva, na busca de sentidos outros. Ao dizer-se que a metodologia é eficaz, dinâmica e atraente como nas unidades do E4, sugere-se que em outra instituição, essa eficácia, dinamismo e atração não existiriam, ou seja, na sua escola não há esse tipo de ensino eficaz, e este ensino está nas unidades do E4.

O não-dito, neste caso, remete-nos a um conjunto de formulações feitas e já esquecidas, o interdiscurso, compondo uma rede de sentidos. Citando Orlandi (1999), a prática discursiva procura escutar o não-dito naquilo que é dito, como uma presença de ausência necessária, sendo que só uma parte do dizível é acessível ao sujeito, pois, mesmo o que ele não diz e que muitas vezes desconhece, significa em suas palavras.

No item economia, notamos novamente a importância da "vantagem" de pagar menos (em relação a outras escolas), mas mantendo a qualidade, portanto, obtendo-se lucro, de certa forma. Destaca-se aqui também, a intenção de sugerir que a emissão do certificado é mais uma vantagem, através do termo inclusive. $\mathrm{O}$ termo denota a inclusão do certificado como vantagem ou lucro, quando na verdade é algo de direito ao se terminar qualquer curso reconhecido.

No item qualidade, afora todas as outras citações sobre essa questão já anteriormente citadas, salientamos que aqui, o foco está no sujeito-professor. Destacamos a visão adotada pela mídia, como vemos em trabalho de Carmagnani (2004) em que a autora cita a representação do que é ser professor hoje no Brasil. Essa representação, ela salienta, tem sido repetidamente negativa produzindo um efeito de verdade inquestionável na sociedade. Por isso, na propaganda, vemos a intenção de se ressaltar que, se os professores forem os da outra escola, supostamente ruins e não preparados - note-se novamente aqui o sentido do não-dito, através do interdiscurso - haverá um processo de treinamento e supervisão, para a garantia da qualidade esperada. Salientamos neste ponto, a intersecção do discurso pedagógico com o empresarial, no que se refere ao controle da qualidade. Segundo Gentili (1999), esse é um dos cinco aspectos centrais para a garantia da qualidade: o controle. Deve haver modalidades 
específicas de disciplinamento e controle para a garantia do processo produtivo. Transpondo para o campo educacional, vemos esse poder controlador e disciplinador nos treinamentos e supervisões propostos na propaganda.

Desde o início de nossas análises sobre as propagandas da terceirização educacional do ensino de línguas estrangeiras, partimos do pressuposto de que a visão mercadológica e político-empresarial tem se fixado no campo educacional de forma avassaladora, na sociedade neoliberal atual. Os variados discursos que permeiam essa sociedade produzem ideologias, que constroem as posições de sujeitos com as quais nos identificamos, construindo assim nossas identidades.

A operação estratégica do neoliberalismo, ao transferir a educação da esfera da política para o mercado questiona o seu caráter de direito e reduz sua condição a de propriedade. Gentili (2005) demonstra que é nesse quadro que a noção de cidadania toma um outro conceito, através de uma revalorização da ação do indivíduo como proprietário, como indivíduo que luta para conquistar, ou comprar, propriedades-mercadorias, das mais diversas categorias, sendo a educação uma delas.

Assim, neste contexto histórico-social neoliberal, o discurso pedagógico de língua estrangeira reproduz a educação também como um bem de consumo e, consequentemente a escola, como um espaço mercadológico.

Os sujeitos produzidos a partir desse discurso mercantilista são: um professor de línguas tecnicista, que assume a identidade de técnico aplicado ao aperfeiçoamento do imaginário de "dominar" a língua estrangeira; um aluno, que interpelado pelo mesmo discurso transforma-se em cliente, em um consumidor, acreditando que ao obter o produto, no caso a língua estrangeira, terá acesso a um status, que o tornará mais completo e, fará ocupar outros lugares sociais, premissas estas incertas em suas concretizações.

Para a produção, reprodução e validação dessas ideologias, a mídia tem desempenhado um papel importantíssimo utilizando discursos políticos, econômicos, científicos e, muitas vezes, como no caso desta análise da propaganda institucional educacional, fazendo-o em detrimento do discurso pedagógico. Nesse sentido, não se percebe o interesse da mídia em contribuir para a disseminação de um ensino comprometido com a educação, pois não leva em conta os objetivos educacionais e formadores pertinentes à aprendizagem de uma língua estrangeira. 


\subsubsection{Outros conflitos: analisando os objetivos}

Ao observarmos as atuais tendências de busca de soluções para o problema do ensino de língua estrangeira fora da escola, como na terceirização, percebemos que muitas vezes, isso ocorre devido a uma interpretação construída com seus próprios vieses ideológicos. Esta mostra-se conflituosa em relação aos objetivos desse ensino em um instituto de idiomas e os objetivos de uma escola de educação formal.

A partir de agora retomaremos essa questão dos conflitos de objetivos desses dois modos de ensino, na tentativa de melhor entender o fenômeno da terceirização.

Citando os documentos preparados pelos órgãos governamentais brasileiros, com destaque para os objetivos educacionais do ensino de línguas estrangeiras na educação básica, os PCNs, há a seguinte citação:

A aprendizagem de Língua Estrangeira contribui para o processo educacional como um todo, indo muito além da aquisição de um conjunto de habilidades linguísticas. Leva a uma nova percepção da natureza da linguagem, aumenta a compreensão de como a linguagem funciona e desenvolve maior consciência do funcionamento da própria língua materna. Ao mesmo tempo, ao promover uma apreciação dos costumes e valores de outras culturas, contribui para desenvolver a percepção da própria cultura por meio da compreensão da(s) cultura(s) estrangeira(s). O desenvolvimento da habilidade de entender/dizer o que outras pessoas, em outros países, diriam em determinadas situações leva, portanto, à compreensão tanto das culturas estrangeiras quanto da cultura materna. Essa compreensão intercultural promove, ainda, a aceitação das diferenças nas maneiras de expressão e de comportamento (PCN, 1998, p. 37).

Nos documentos governamentais, com as mesmas intenções de dar suporte aos profissionais da área de educação quanto ao ensino de língua estrangeira, agora dedicados ao ensino médio (OCEM, 2006), comenta-se que a instituição escola formal e a instituição escola de idiomas, têm seus objetivos diferentes, pois têm finalidades diferentes também. Segundo o documento, quando há falta de clareza em relação a isso, há a tendência de concentrar-se no ensino apenas linguístico ou instrumental do ensino de idiomas, desconsiderando os outros objetivos educacionais e culturais que permeiam o ensino de línguas estrangeiras, como se esta pudesse ser aprendida de forma neutra ou isolada de valores sociais, políticos ou 
ideológicos. E de acordo com o referido documento, assim como as outras disciplinas escolares, as línguas estrangeiras na escola de educação formal têm o compromisso de contribuir para a formação educacional dos indivíduos. (OCEM, 2006, p. 91)

A partir das mencionadas orientações curriculares, entende-se que pensar em objetivos para o ensino de língua estrangeira na escola de educação formal, vai muito além dos aspectos linguísticos ou instrumentais de cada idioma. Ao focalizarmos uma concepção de educação que concentra mais esforços no conteúdo, como se fosse possível separar da língua seus valores sociais, culturais, políticos e ideológicos, deixamos de lado um dos objetivos educacionais prioritários da educação: o aprendiz e sua própria formação como indivíduo e como cidadão.

Corroborando esse pensamento, Jordão (2009), declara que a sala de aula de língua estrangeira pode ser o contexto ideal para a resistência à imposição de caminhos que homogenizam o conhecimento, estando primariamente preocupada em mostrar como as línguas constroem e distribuem os sentidos a partir de espaços históricos, ideológicos, geográficos e concretos. Jordão (2009) ainda enfatiza que a prática do ensino de língua estrangeira, especialmente o inglês, precisa considerar a educação a partir do letramento crítico, cuja grande preocupação é com o poder das línguas como processo de criação de sentidos, além da necessidade de mudança e a constante abertura a diferentes procedimentos interpretativos. Ao criticar, o ensino de inglês como língua globalizada, a autora ressalta a expectativa que se pode ter quanto aos letramentos críticos, entendendo que nestes seja possível encontrar

caminhos para opor-se ao desejo da modernidade por formas linguísticas monofônicas, um desejo que inferioriza o híbrido, o caráter polifônico de todas as línguas (Bakhtin, 1982 apud Jordão, 2009), e as reduz a estruturas abstratas cujo papel seria simplesmente o de mediar nosso contato com o mundo (op. cit. p.100).

Portanto, em termos de objetivos, espera-se que o ensino de língua estrangeira na escola de educação formal possa evidentemente voltar-se para ensinar um idioma estrangeiro e, ao mesmo tempo, cumprir outros papéis da educação, como qualquer outra disciplina também pode fazê-lo. 
Partindo desse pressuposto supomos ser relevante distinguir os objetivos de uma escola de idiomas e os de uma escola de educação formal; a primeira, envolvida nas prioridades linguísticas: a língua estrangeira com todos os aspectos pertinentes à sua aquisição; enquanto à segunda, preocupada com sua função educativa, caberia buscar contribuir na formação dos cidadãos, especialmente para os estudantes mais jovens.

Pennycook (1999), também reitera os objetivos educacionais do ensino de línguas, declarando que um dos problemas do divórcio do aspecto linguístico com o aspecto educacional, é o de lidar com esse ensino como se fosse um fenômeno predominantemente cognitivo, isolado dos contextos educacionais, culturais e sociais. "É essencial que como professores de línguas, não pensemos só sobre a língua, mas também sobre a educação e a desigualdade" (op. cit. p. 299).

Sob esse conceito de uma educação baseada em um desejo de mudança social, Pennycook (2001), considerando as bases da pedagogia crítica descrita por Giroux (1988, 1991), sugere que o grande desafio da escola é construir uma teoria e uma prática de educação que possa, por um lado, fazer com que os que estão em desvantagem social obtenham a possibilidade de ascensão e, ainda por outro lado, desenvolver maneiras de práticas de ensino que possam oferecer essa possibilidade a essas minorias, oferecendo uma melhor chance de sucesso, não necessariamente como tradicionalmente se entende "sucesso", mas transformando até mesmo a noção do que esse "sucesso" poderia significar.

Nessa educação transformadora, Pennycook elenca algumas características da pedagogia crítica: a educação não produz só conhecimento, mas também visões políticas; ética é um aspecto central da educação; há que se esclarecer as diferenças sobre como as identidades de professores e alunos são formadas e de como essas diferenças entre os grupos são mantidas; o currículo do saber não é sagrado, pode ser questionado, podendo ser aberto a outros tipos de cultura e conhecimento; a pedagogia crítica não deve apenas se limitar a questionar ou criticar formas de saber já impostas, mas trabalhar na direção da criação de novas formas de conhecimento; rejeitar a objetividade em favor de versões mais parciais e particulares do conhecimento, da verdade e da razão; deve incluir não somente uma linguagem crítica, mas uma visão que envolva até mesmo certa utopia com uma crença em possibilidades alternativas; os professores devem ver a si mesmos como intelectuais transformadores, derrubando por terra a visão de tecnicista do ensino, onde sua função seja a de apenas transmitir conhecimento; a pedagogia crítica trabalha com a noção de "promover a 
voz", enfatizando a natureza política do sujeito, estimulando sua capacidade de participação ativa e transformadora na sociedade (op. cit. p. 297-299).

Dentro dessa visão da pedagogia crítica, a escola torna-se uma das principais arenas políticas e culturais onde diferentes formas culturais, ideológicas e sociais estão em constante conflito. Apreende-se que, a escola é o lugar onde se preservam e se repassam ideologias e valores, muito embora este papel venha sendo obscurecido pela falta de visão dialógica entre concepções humanistas e behavioristas da educação, conforme salientado nas perspectivas de Giroux (1997).

Apreende-se também que ambas as escolas, a humanista e a behaviorista, ignoram a importância de se desenvolver objetivos que enfatizem o relacionamento da teoria com os fatos de forma crítica. Seria a relação entre teoria e prática que, de certa forma, permite que vejamos o que vemos, que aprendamos a olhar. Diferentes modelos teóricos geram maneiras distintas de se ver o mundo, daí a sua importância.

Neste ponto da discussão, cremos ser bastante oportuno destacarmos como os novos letramentos ou multiletramentos (LANKSHEAR e KNOBEL, 2003; KRESS, 2003) podem ser importantes quando se pensa em termos de objetivos educacionais relacionados à educação linguística. Segundo Monte Mór (2009), os letramentos têm se tornado temas centrais às políticas educacionais, formação de currículos e discussões sobre práticas educacionais do dia a dia.

Como já apontado em capítulo anterior, as definições de letramento tradicionalmente relacionam-se com a aquisição de leitura e escrita, ou ainda particularmente referiam-se a adultos não-letrados, tratando-se de programas específicos de alfabetização. Segundo Lankshear e Knobel (2003), alguns fatores foram importantes para incrementar o desenvolvimento de teorias específicas de letramento, a partir de 1970; dentre eles, destacamos os seguintes: primeiramente, o movimento de educação radical desenvolvido por Paulo Freire, no final dos anos 60 e inícios dos anos 70, que propunha o conceito de letramento "ler as palavras e ler o mundo", envolvendo muito mais do que um mero decodificar de signos linguísticos, e também a construção de uma prática social, com reflexão crítica e ação; um segundo fator de desenvolvimento dos letramentos nas novas perspectivas educacionais, foi a descoberta, especialmente nos Estados Unidos, de uma crise de preparo para o enfrentamento das novas demandas econômicas e sociais, numa sociedade pós- 
industrial, onde os alunos, depois de passar pelas instituições escolares, não davam conta das mudanças nas organizações e instituições que tinham de enfrentar no dia a dia; e finalmente, o desenvolvimento das perspectivas socioculturais dentro dos estudos da linguagem e das ciências sociais (GEE, 1996).

Em face do impacto das novas tecnologias e da grande diversidade cultural e linguística provocadas por tempos de globalização nesta era da pós-modernidade, as necessidades dos estudantes em relação aos letramentos, tanto em dimensões culturais quanto operacionais, têm mudado fortemente o foco dos objetivos pedagógicos no ensino das linguagens.

Uma nova epistemologia, tanto do conhecimento quanto da pedagogia, voltada para essas necessidades de multiletramentos, dispõe-se a ir além da tecnologia da escrita, como um processo ininterrupto de aprendizagem, um exercício efetivo de uma prática social situada política e ideologicamente em diferentes espaços sociais e culturais. Para esta, amplia-se a importância na proposição de objetivos educacionais para o estudo das linguagens, seja na área da língua materna ou da língua estrangeira.

Outro aspecto importante na composição dos objetivos educacionais no ensino de língua estrangeira é a noção de capital cultural, que são todos os atributos - linguísticos, cognitivos, experienciais - que os diferentes estudantes já trazem em si.

Na perspectiva crítica de Bourdieu, segundo Nogueira e Nogueira (2006), existem hierarquias culturais, que legitimam e reforçam as hierarquias sociais mais amplas da sociedade, dividindo-a em grupos, classes e frações, de dominantes e dominados. A noção de capital cultural, análoga ao capital econômico, envolve prestígio e poder, que vem da produção, da posse, da apreciação ou do consumo de bens culturais socialmente dominantes. Nessas hierarquias, o uso da língua em seu padrão culto - reconhecido como correto - por exemplo, dá uma série de benefícios e vantagens sociais ao seu usuário, sendo que a escola e os especialistas da linguagem, classificam-nas e atribuem valor à elas. "O uso da língua funciona como uma moeda, um capital...” (op. cit. p. 41). Por essas asserções, vê-se que é possível comparar, o ensino da língua estrangeira, especialmente o inglês, como mais um bem cultural hierarquizante das sociedades globalizadas atuais.

Na visão de Ribeiro Junior (1982), a teoria de Bourdieu acentua um contraste com os ideais positivistas da educação. Segundo esses ideais, as principais características da escola 
baseavam-se na liberdade individual para a luta e superação em busca das conquistas sociais, onde paradigmas modelares eram básicos, e a busca do equilíbrio, da paz e da harmonia eram o significado de democracia. À escola era atribuído o papel duplo de superar atrasos econômicos e sociais, bem como o papel de construir uma sociedade justa - baseada no esforço pessoal e meritocrático; uma sociedade moderna - que se pautasse no conhecimento científico e na racionalidade; e uma sociedade democrática - onde a autonomia individual representaria garantias. Esse ideário defendia ainda que a escola, pública e gratuita, seria uma instituição neutra, difusora de um conhecimento único, racional e objetivo, e que todos teriam acesso à educação. Essa educação garantiria igualdade de oportunidades, onde todos competiriam, em condições iguais, e a partir de sua aptidão e dons individuais; os indivíduos teriam, ao se destacarem, a possibilidade de galgar até posições superiores na hierarquia social (NOGUEIRA e NOGUEIRA, 2006). Contrariamente, a visão da educação na concepção de Bourdieu (1964), inverte a perspectiva que atribuía à escola características de um pólo transformador e democratizador das sociedades, para uma das principais instituições que mantém e legitima os privilégios sociais. Onde o Positivismo via igualdade de oportunidades para o sucesso a partir de luta pessoal, meritocracia que conduziria a uma justiça social, Bourdieu vê apenas a reprodução e a legitimação das desigualdades sociais.

Sob essa mesma perspectiva, destacamos Giroux (2006), corroborando a análise de como as escolas funcionam como agências de reprodução social e cultural e de como elas legitimam a racionalidade capitalista e sustentam as práticas sociais dominantes, no seguinte trecho:

Contrário aos reclamos dos teóricos e historiadores liberais que dizem que a educação oferece possibilidades para um desenvolvimento individual, mobilidade social e política, e poder econômico para os que estão em desvantagem, os educadores radicais têm argumentado que uma das principais funções da escola têm sido a reprodução da ideologia dominante, suas formas de conhecimento e a distribuição de habilidades necessárias a reproduzir a divisão social do trabalho (op. cit. p. 3).

Ao comentar sobre a função social dos professores, Giroux (1997) ainda destaca a não neutralidade do espaço dessa instituição social: a escola. Mais do que repassar um conjunto de valores e conhecimentos, para o autor, as escolas são espaços sociais, culturais e econômicos 
que estão intimamente ligados a questões de poder e de controle; o espaço da escola serve para introduzir e legitimar valores e relações sociais, conhecimentos e práticas de linguagem, que podem selecionar e excluir das práticas sociais como um todo.

O conflito de visões de escola como um espaço social legítimo e dinâmico de política e poder, ganha destaque em nosso estudo, concluindo-se que o ensino de línguas se destaca como um meio, conforme indaga Fairclough (1989), para avaliar se "as ordens existentes no discurso ideológico, bem como as já existentes relações de poder, devam ser reproduzidas ou transformadas" (op. cit. p. 244).

\section{CAPÍTULO 3 - A PRÁtiCA dA TERCEIRIZAÇÃo}

Por meio dos instrumentos utilizados na pesquisa - entrevistas formais e informais, observações das aulas terceirizadas - duas questões principais salientam-se no que concerne à prática da teceirização do ensino de língua estrangeira nas escolas de educação formal: a heterogeneidade e a formação docente na parceria terceirizada. As análises serão estruturadas sob esses dois eixos principais interligando as interpretações dadas aos instrumentos utilizados, sob o locus das teorias dos novos letramentos e dos multiletramentos.

\subsection{Dificuldades para se lidar com a heterogeneidade na escola de educação formal; a padronização e o modelo}

As observações das aulas terceirizadas, as quais foram agendadas previamente pela coordenadora do English Center, deram-me a oportunidade de visualizar na prática, detalhes do dia a dia da terceirização das aulas de língua estrangeira em variados níveis e intepretá-los 
à luz das teorias da Pedagogia Crítica (FREIRE 1996; GIROUX, 1997) e dos Multiletramentos (GEE, 1990, COPE e KALANTZIS, 1996; LANKSHEAR e KNOBEL, 2003). Inicialmente as análises são feitas selecionando os fatos que se repetem, de forma agrupada, gerando assim uma determinada interpretação. Depois, são destacados fatos específicos que puderam ter uma determinada interpretação em sua análise.

Considerando que as turmas da escola I.S. não são numerosas, no máximo 20 alunos por sala, as classes iniciais como $1^{\mathrm{a}}$ e $2^{\mathrm{a}}$ séries, não têm divisão em níveis de aprendizagem de língua, porque segundo informações de um dos professores, a maioria dos alunos dessas séries iniciais teve um contato mínimo com o idioma na pré-escola, não havendo, portanto, a necessidade da divisão. Já nas turmas de $5^{\mathrm{a}}$ até $8^{\mathrm{a}}$ série, a divisão por níveis foi necessária, visto que muitos alunos já haviam estudado em escolas de idiomas anteriormente, tendo um conhecimento prévio diverso. Essa divisão acontece através da aplicação de um teste de nivelamento, baseado em conhecimentos linguísticos, no início da parceria, repetindo-se a cada início de semestre para os alunos novos. Assim, as classes de $7^{\mathrm{a}}$ e $8^{\mathrm{a}}$ séries, por exemplo, estão misturadas em níveis básico, intermediário I e II e alguns em nível avançado. Dentro do currículo as aulas de Inglês mantêm sua periodicidade normal de qualquer escola de educação formal, duas vezes por semana, com 50 minutos cada.

Ao verificar-se o fato da divisão dos alunos por níveis linguísticos, relembrando que esta foi uma preocupação da diretora ao nos expor as razões para a busca da terceirização, pode-se notar implicitamente, uma concepção de língua como sendo apenas um instrumento, uma ferramenta para a comunicação, um objeto situado fora do sujeito e dos contextos ideológicos e sociais.

Pennycook (1994), comentando sobre a expansão da língua inglesa e sua acepção como língua internacional, destaca a visão na qual a língua é uma ferramenta a serviço da comunicação, da divulgação da ciência e da cultura; nessa perspectiva, observa o autor, enfatiza-se o caráter de neutralidade e de utilidade da língua, o que permite que as suas marcas ideológicas e políticas sejam silenciadas quando tidas como inerentes à sua constituição.

Evidências desse fato são notadas principalmente nas séries iniciais observadas, de $1^{\mathrm{a}}$ a $4^{\mathrm{a}}$ séries, nas quais as aulas seguem praticamente um mesmo modelo e sequência, o qual pareceu bastante rígido, com sequências pré-definidas, sendo que diferentes professores seguem basicamente a mesma ordem: música introdutória, com exercício referencial no livro 
ou não; apresentação ou revisão de vocabulário; apresentação do conteúdo (tema) da aula e jogo com base no tema apresentado.

Comentando sobre o caráter produtor e principalmente reprodutor de ideologias dentro das escolas, Giroux (2006) destaca como essa dominação reguladora das aulas, tem sua materialidade na existência dos rituais, rotinas e práticas sociais específicas do dia a dia escolar. Ele ainda apresenta essa ideologia, como se fosse um currículo oculto, que dessa forma, define-se num sistema de sentidos, valores e representações, envoltos em tais práticas concretas induzidas ao inconsciente de alunos e professores.

Em oposição a essa reprodução inconsciente produzida pelas escolhas metodológicas, Giroux (2006) postula que a pedagogia deve promover práticas que desenvolvam a cidadania e a agência. As práticas de sala de aula devem possibilitar condições para um questionamento do conhecimento, das habilidades e da cultura,

necessárias para os estudantes se integrarem em um diálogo crítico com o passado, questionando autoridade e seus efeitos, problematizando as relações de poder vigentes, e "preparando-se para o que significa ser um cidadão criticamente ativo e interrelacionado com esferas locais, nacionais e globais (op. cit. p. 216).

Na visão da pedagogia crítica, a repetição dos modelos impostos, não salienta a possibilidade de o professor exercer agência. O mesmo autor (GIROUX, 2006) aponta para a necessidade de haver uma flexibilidade tanto para a escolha quanto para a consecução dos currículos escolares, aumentando sua autoridade pedagógica e não separando-as de questões sociais mais amplas.

Outras atitudes que são normalmente repetidas pelos professores, seguindo um modelo básico, são: a utilização de exercícios orais repetitivos, com estruturas de perguntas e respostas prontas; divisão da sala em grupos por gênero, meninos contra meninas e vice-versa, para todos os games, gerando sempre uma competição muito acirrada; além disso, há um outro reforço cultural para a diferenciação de gênero com o famoso "girls first" para qualquer atividade, onde sempre as meninas têm a primazia; repetição de frases temáticas do conteúdo principal da aula ou do vocabulário, em várias tonalidades de voz, fazendo um jogo de repetição. Observei que algumas atitudes disciplinares como apagar a luz quando o barulho é intenso demais; colocar o aluno indisciplinado para fora da sala por cinco minutos, também se repetiam.

Salientamos que muito embora nessa linha pedagógica notadamente de caráter behaviorista, haja uma visão específica de linguagem, de cultura e de poder, cremos ser 
importante destacar que esses conceitos subjazem a uma das idéias positivistas mais básicas, que é a da criação de modelos e paradigmas a serem seguidos (RIBEIRO JUNIOR, 1983). Interpretamos que a própria concepção do ensino de língua terceirizado, anuncia e responde a uma espécie de reflexo do outro, um "efeito espelho", do método, do livro didático, do professor proficiente, enfim, do produto final que seria a aprendizagem eficaz da língua, pertencentes ao instituto de idiomas, como um modelo a ser seguido.

Nessas práticas relacionadas anteriormente, ainda enfatizando a divisão classificatória determinada pelos níveis linguísticos de cada aluno, percebe-se uma busca de harmonia e equilíbrio para a realização da aprendizagem. Essa idéia positivista disseminada pelo neoliberalismo de equilíbrio e padronização excetua o múltiplo, o diferente, considerando qualquer coisa que gere conflito, como um empecilho de crescimento. Embora a divisão por níveis linguísticos no ensino de língua estrangeira seja um exemplo típico dessa busca de homogeneização na escola, ela não é única; outros variados exemplos da prática da vida escolar podem ser citados, tais como: uso de uniformes; modelos padronizados de avaliação; divisão por séries e por disciplinas estanques; ensino da gramática normativa como base; o próprio modelo de transmissão de conhecimento, onde o professor é o transmissor e o aluno, o receptor, em grande parte das práticas pedagógicas registradas e analisadas. Nessa visão de educação, crê-se em uma identidade única, esquecendo-se que a heterogeneidade constitui o sujeito. Por outro lado, numa visão dialógica de aprendizagem, as diferenças, a falta de certezas, o conflito em si, pode gerar crescimento e transformação. Para Coracini (1995), a possibilidade da alteridade na sala de aula e a concepção da heterogeneidade como constitutiva da linguagem e de todo sujeito poderia trazer aos professores um melhor entendimento da aprendizagem em si, percebendo que seus alunos aprendem de modos diferentes, em momentos diferentes, fazendo relações diferentes. Coracini (1995) ainda destaca que defende

a consideração da heterogeneidade, não como o outro lado da polarização, mas como constitutiva do sujeito e do dizer em conflito permanente com o desejo da homogeneização, da perfeição, da unicidade. Se não é possível apagar esse desejo, também não é possível apagar a heterogeneidade constitutiva, que torna complexo, o que parece simples, múltiplo o que parece uno, conflitante, o que parece controlável pela razão e pela ciência (op. cit. p. 265).

Essa posição da busca por homogeneidade na sala de aula de línguas estrangeiras, através do nivelamento linguístico, tenta uma busca de solução que pretende dar conta da 
diversidade, transformando o que é tido como caos da heterogeneidade, ingovernável e incontrolável, em algo gerenciável. Essa parece ser uma tendência característica da cultura ocidental, buscando a homogeneidade como fator simplificador da ação humana e como fator positivo, rumo à harmonia, ao equilíbrio e à igualdade, não só no âmbito da aprendizagem de línguas, mas em toda e qualquer relação humana permeada pelos conflitos e pelas contradições (CORACINI, 1995, apud RAJAGOPALAN 1997).

Outras evidências sobre a ênfase dada para a padronização são observadas no que concerne à utilização de materiais didáticos, como por exemplo, o livro didático. Durante as aulas observadas, um livro didático elaborado pela própria instituição English Center, foi utilizado em todos os níveis, com exceção da $7^{\mathrm{a}}$ série que não utilizou o livro naquela aula, pois tratava-se de uma aula pré-prova e também introdutória a um novo assunto. Embora uma análise específica do material, no caso o livro, não seja objetivo deste levantamento de dados, ao observar o conteúdo dos livros das variadas séries, pode-se perceber uma sequência estrutural gradativa, com vocabulário e estruturas gramaticais indo do considerado mais fácil ao mais difícil, denotando a preocupação com os aspectos estruturais do ensino de língua. Um equipamento utilizado em todas as aulas é um aparelho de CD, levado pelas próprias professoras para cada sala de aula. Há um aparelho para cada uma, pois elas o utilizam geralmente na mesma hora, ao iniciar a aula. Cartazes com figuras específicas, utilizados mais nas séries iniciais, para introdução de vocabulário e também para alguns jogos, também são materiais bastante utilizados.

Diante destes dados acima citados podemos observar a grande preocupação com os aspectos linguísticos do ensino de língua através da intensidade da prática das repetições, utilizando-se metodologias baseadas em conceitos behavioristas, baseando-se em materiais que seguem conteúdos que refletem uma epistemologia convencional, por exemplo, prédeterminados em mais fáceis e mais difíceis, preocupados em atender as quatros habilidades linguísticas, voltando-se, portanto, para uma visão estruturalista de linguagem.

Novamente destacamos que essa é uma visão que entende a linguagem, a cultura e o conhecimento como totalidades estanques e isoladas. Entende-se que a linguagem, quando considerada de maneira abstrata, distante e desvinculada de seus contextos socioculturais e de suas comunidades de prática, pode resultar em prejuízos graves nos âmbitos humano e pedagógico. (OCEM, 2006)

$\mathrm{Na}$ epistemologia convencional, segundo descrição de Morin (2000), há uma promoção da educação reprodutiva ao invés do desenvolvimento de uma mente criativa, 
concentrando-se em princípios pedagógicos reducionistas - como na divisão dos conteúdos dos livros didáticos - e também fragmentados por graduação - como nas metodologias tradicionais de ensino de línguas que partem do considerado mais fácil para o mais difícil (MONTE MÓR, 2009). Ainda segundo Monte Mór (op. cit.), baseando-se em suas próprias pesquisas e de outros estudiosos da área, como Lankshear e Knobel (2003), essas mudanças epistemológicas parecem fundamentais para adequar o ensino nas escolas secundárias e fundamentais, bem como na formação de professores, às expectativas dessas novas sociedades e suas necessidades, salientadas, por exemplo, pelos novos processos de construção do conhecimento, estimulados pelas novas tecnologias digitais, posto que estas não mais enfatizam modelos e padrões, outrossim, enfatizam a interação e a criatividade na produção do conhecimento.

Assim, as propostas recentes sobre letramento que se afastam de uma concepção de língua, cultura e conhecimento como totalidades abstratas e se baseiam numa visão heterogênea, plural e complexa, sempre inserida em contextos socioculturais, podem fazer parte de uma possível revisão dos fundamentos pedagógicos sobre ensino e aprendizagem de línguas. Os novos letramentos e multiletramentos como prática sociocultural, podem interagir com novos insumos, que podem gerar transformações de forma crítica e eficaz (COPE e KALANTZIS, 2000; GEE, 2000).

Outras evidências de ênfase na busca da homogeneidade bem como na relevância da padronização e dos modelos como fato de grande importância para a garantia da aprendizagem eficaz no ensino de línguas estrangeiras são percebidas nas conversas com os professores, coordenador do instituto de idioma e também com alunos, seja em entrevistas formais ou informais.

Em alguns momentos informais em conversa na sala dos professores, em sua fala, os mesmos demonstram ainda haver uma clara preferência da maioria pelo trabalho realizado no instituto de idiomas em relação ao trabalho na escola terceirizada. Os professores argumentam sua preferência baseando-se especialmente nas condições de trabalho de um e outro espaço escolar - especialmente as condições materiais adequadas - desde o aparato tecnológico de ponta, até o número menor de alunos.

Outro fato a ser ressaltado é que os professores comparam os alunos dos dois modelos de escola em termos de motivação, sendo que, segundo eles, os alunos do instituto de idiomas vêm com a vontade ou a necessidade de realmente aprender a língua estrangeira, enquanto que os outros, da escola de educação formal, não tendo esse mesmo interesse ou necessidade, 
precisam ser constantemente motivados, muitas vezes, gerando problemas disciplinares e de aproveitamento por conta disso. Depreende-se dessa fala, primeiramente, que os professores não veem diferenças nas duas propostas de ensino em termos de objetivos, ou seja, em sua visão, o instituto de idiomas e a escola de educação formal têm como objetivo primordial ensinar a fluência no idioma estrangeiro, destacando-se aqui a visão objetiva e instrumental que subjaz a esse pensamento, não colocando em relevância os objetivos educacionais que tanto a língua estrangeira como as outras disciplinas escolares têm em relação ao compromisso na formação do indivíduo. Reiteramos, segundo Monte Mór (2006), que possa haver semelhança de finalidades entre os dois modelos escolares, no entanto há diferenças de objetivos. Além disso, nesta fala, os professores parecem ignorar o fato de que é impossível só ensinar língua, ou ainda, nos dizeres de Pennycook (1994, p.295), "só ensinar, ou ensinar só língua", diante das dimensões sociais e políticas da mesma.

Em segundo lugar, também depreende-se que exista uma visão binária na análise dessa situação escolar de eficácia e ineficácia, tanto por parte dos professores que veem melhores condições de ensino na escola informal, quanto por parte dos alunos, que quando querem realmente aprender, procuram esse formato escolar, o da escola de idiomas, que lhes garante o aprendizado com qualidade.

A respeito dessa visão, Monte Mór (2006) aborda a presença do binarismo nas análises das escolas

na classificação do ensino eficaz ou ineficaz, realizado dentro de condições favoráveis ou desfavoráveis, representando um trabalho desejado ou indesejado, quer seja na opção pelo trabalho, quer seja na análise do que se quer realizar pedagogicamente. Binário em seu sentido de exclusão, pois, se o ensino de línguas estrangeiras nos níveis fundamental e médio se tornou para muitos, ou mesmo que fosse para alguns, ineficaz, sem condições favoráveis para ser realizado, com resultados indesejados, ele permitiu construir uma imagem para si próprio como a de um modelo inapropriado (p. 358).

Percebe-se assim, uma busca pelo padrão e pelo modelo oferecido no instituto de idioma como sendo aquele que realmente possui estrutura e características que possam oferecer um ensino de língua estrangeira que seja realmente eficaz.

Em uma segunda fase das entrevistas, pude ter um contato mais formal com dois professores, escolhidos pela coordenação do instituto de idiomas English Center, os quais foram indagados sobre várias questões, desde sua formação pedagógica até o seu contato com 
a terceirização junto ao colégio I.S. Nas análises a seguir denomino P1, professor 1; P2, professor 2; e C1 o coordenador do instituto de idiomas English Center.

Tanto P1, quanto P2, são professores com formação em Letras; P1, além dessa formação é também formado em Publicidade; P2 é bacharel em Letras, terminando sua licenciatura. Ambos relataram ter vários títulos internacionais de proficiência de língua inglesa, bem como cursos internacionais para professores de língua. Ambos lecionam tanto no instituto de idiomas, English Center, como na escola I.S. P1, com uma experiência maior na profissão, já lecionou em outras escolas e está desde o começo da terceirização trabalhando nas duas instituições, há cerca de quase quatro anos; P2, leciona há cinco anos no English Center e há dois anos na Escola I.S. Na época da entrevista, ambos trabalhavam com turmas de variados níveis - crianças, adolescentes e adultos. Vale ressaltar que a escolha destes professores específicos para as entrevistas formais não foi aleatória, sendo indicada e agendada pelo coordenador do English Center.

Ao serem perguntados sobre a importância dada à classificação dos alunos por nivelamento linguístico evidencia-se o mesmo fato que nas observações de aula e nas conversas informais: o desejo da homogeneidade. P1 destaca, por exemplo, que "quando as crianças estão aprendendo inglês, tem que acompanhar o que elas aprendem em português, a gente não pode ir além disso...", inferindo-se disso que, este nivelamento é algo facilitador para que a aprendizagem ocorra de maneira eficaz e com a qualidade desejada, demonstrando a asserção da idéia de equilíbrio e padronização, que desconsidera o múltiplo, o diferente, considerando a possibilidade de conflito como um entrave para o crescimento.

Sob esse mesmo tópico, P1 ainda declara que faz-se o nivelamento quando o aluno "já sabe um pouquinho de inglês" e ainda, mais adiante, ao comentar sobre o conhecimento em relação à língua materna (ter escrita ou não), "então, dependendo do nível dela, mesmo que ela esteja um pouquinho à frente no inglês, mas ela não sabe escrever ainda, ele tem que ver cada coisa no seu tempo...", depreende-se que a experiência com a língua, o conhecimento dela, e ainda o conhecimento em relação à língua materna, são caracterizadas como diferenças entre os alunos, que à primeira vista em sua fala, precisam ser contempladas, para que a aprendizagem da língua estrangeira se efetue. A categorização em níveis de conhecimento parece, portanto, contemplar as individualidades e as heterogeneidades. No entanto, essa visão, nos parece camuflar, de uma forma prescritiva, o que se deve aprender, quando e ao lado de quem, e isso acaba por anular as particularidades dos sujeitos que estão na sala de aula, além de desconsiderar a possibilidade da existência de conflitos. Essa definição de 
nivelamento é feita pela escola terceirizada, segundo um planejamento prévio desta, utilizado para o ensino fora da escola regular e que é transposto para a educação formal. Apesar de aparentemente essa prática ter objetivos individualizantes, os seus pressupostos teóricos são generalizantes, a saber, uma língua homogênea e sujeitos indivisos. Nos dizeres de Coracini (1995),

$\mathrm{O}$ respeito à diversidade, (...), parece se dar, pois, em termos relativos, ou seja, trata-se de uma diversidade de ordem metodológica (...), que consistiria na soma de aspectos individuais que, na verdade se desvinculam das situações reais (...) Por outro lado, a homogeneização do sujeito leva à desconsideração dos conflitos inerentes à heterogeneidade que o constitui (p. 260).

Nas perguntas sobre as diferenças entre os dois modelos de ensino de língua, o da escola de educação formal terceirizada e o do instituto de idiomas, percebe-se uma relevante ênfase no fato de que não há diferença entre um modelo e outro, acentuando-se que objetivos, metodologias e uso de material são os mesmos em ambos os casos.

Tanto P1 quanto P2 destacam em suas respostas que as diferenças entre os dois modelos de escola são apenas no aspecto físico, como disposição de carteiras, uso de alguns aparatos tecnológicos que em um modelo são disponíveis e em outro não, exemplificados nas falas de P1 e P2, respectivamente: "Então a diferença é um pouco física, na questão do ensino não existe diferença; o que a gente faz lá, a gente faz aqui da mesma maneira. $O$ método que a gente aplica lá a gente também aplica aqui. O que difere é que, por exemplo, no English Center nós temos um quadro interativo... / Ahn, o que pode se ver de imediato, é que no English Center a gente tem um [apa], aparato tecnológico disponível, mas que não me deixa, ahn, que não perde nada na aula que acontece aqui, afinal de contas, antes de termos o tal do quadro interativo, dávamos a aula com quadro branco e canetão."

Nas respostas dos dois professores podemos perceber que ambos enfatizam categoricamente que não existem diferenças entre os dois modelos de ensino, de tal forma que se nota que consideram a possibilidade de diferença como altamente negativa, como se fosse uma perda em qualidade. Infere-se que compartilham do discurso ideológico da ineficácia do ensino na escola de educação formal, que realmente se aprende língua estrangeira no instituto de idiomas, e que, portanto, manter o mesmo ensino do instituto de idiomas na escola terceirizada, é manter a qualidade e a eficácia do ensino tão desejados.

A fala de ambos coloca as diferenças em nível físico, como disposição de carteiras, utilização de materiais diferentes, colocando grande ênfase na metodologia, como prática de 
ensino. Quando P1 é perguntado sobre diferenças metodológicas entre os dois modelos, enfatiza que o método é a sua prática em ambos os modelos: "O método que a gente aplica lá, também aplica aqui.”; P2 chega a nomear a metodologia sócio-construtivista, relacionando aspectos da mesma e ainda enfatizando o fato de ter feito um treinamento especial através de um curso, nesse sentido. Em sua fala detalhando sobre a metodologia apresentada nesse curso, "perceber horário, turma, perfil, idade, questões sócio-econômicas, se pertinentes, enfim. Então, isso me ajuda a planejar melhor a aula e a atingir os mesmos objetivos, fazendo adaptações que eventualmente sejam necessárias ahn, pra sala de aula.", percebe-se que muitas vezes os professores em seus discursos sentem a necessidade da busca de como lidar com a heterogeneidade através de medidas de adaptação, mas ao mesmo tempo, pautam-se na unicidade das metodologias, das receitas práticas prontas, tão sedutoras para a maioria. Vivese uma contradição entre as tentativas de respeitar as diversidades e a forte tendência à homogeneização nas práticas de sala de aula, através das metodologias. Coracini (1995) ao comentar sobre a aplicação das metodologias em salas de aula de línguas declara:

Considerar a heterogeneidade,(...), como constitutiva da linguagem e de todo sujeito, bem como de todas as relações sociais - incluindo-se aí as maneiras e os modos de relação intersubjetiva - levaria à inclusão e à compreensão de situações tidas como desvios, falhas, contradições... Assim, se os linguistas aplicados postulassem a alteridade ou a heterogeneidade, talvez compreendessem melhor as razões pelas quais o sujeito-professor não consegue "aplicar" uma metodologia, apesar de ter discutido e compreendido tão bem as aulas teóricas ministradas por um especialista numa situação de "reciclagem", ou de "formação"(...). A pluralidade de vozes - a assimilação alinear e confusa - conduz a uma concepção de ensinoaprendizagem em que o conflito, a dissonância, a incoerência são parte constitutiva e não problemas a serem sanados por estratégias de apagamento e silenciamento. E isso, com certeza, modificaria as expectativas e reduziria as frustrações (p. 263 e 264).

Assim percebe-se que, na visão dos professores entrevistados, na metodologia reside uma espécie de garantia que visa resistir a essa heterogeneidade inerentes à constituição da linguagem e dos sujeitos, tentando-se, através das mesmas, preservar a homogeneidade, visando qualidade e eficácia no ensino.

Ainda dentro do assunto das diferenças entre os dois modelos educacionais, vale destacar que tanto P1 quanto P2 foram bastante enfáticos em reduzir as implicações das mesmas ao aspecto físico e à utilização dos materiais didáticos, como se percebe nas falas: “ $E$ 
mais a parte física, mas a gente adapta pra trazer pra cá também, então, por exemplo, o que nós faríamos no quadro interativo, por exemplo, a gente mostra um slide de alguma coisa que eles estão aprendendo. (...) Então é a mesma coisa, é como eu te falei... só a parte física, mas a aula seria a mesma, então o aluno tem que levantar da carteira e ir até o quadro interativo e tocar na fruta com a caneta; aqui, fazem uma fila, levantam, correm até a lousa e batem. Então, o princípio é o mesmo, o método é o mesmo, só muda o material, que é digitado”. Na persistência em declarar as igualdades de condições de ensino entre um modelo e outro de escola, os professores acabam por declarar as diferenças entre os modelos de ensino, denotando que na sua visão o material utilizado, não passa de mero instrumento no qual a metodologia se processa, ou seja, não há a consideração de que os meios utilizados na aprendizagem da linguagem são também produtores de significação. Neste ponto, podemos considerar a importante questão dos letramentos, não só dentro das teorias pedagógicas como também em outras áreas do conhecimento. As contínuas mudanças tecnológicas que vêm ocorrendo na atualidade, não podem ser ignoradas em relação a como acabam por transformar valores, epistemologias e práticas sociais. No campo da linguagem, as teorias linguísticas tradicionais não representam mais a linguagem da sociedade, não dão mais conta de ainda considerarem a linguagem construída convencionalmente como o único, ou o mais importante meio de representação ou comunicação. Outros modos, outros meios em que a linguagem ocorra podem ser tão proeminentes e significativos quanto ela própria. Os significados são construídos em bases móveis, diferentes e inconstantes (KRESS, 2003).

Como já descrito em capítulo anterior desta dissertação, as definições de letramento tradicionalmente eram usadas em relação à aquisição de leitura e escrita, ou ainda particularmente em relação a adultos não-letrados, tratando-se de programas específicos de alfabetização. Segundo Lankshear e Knobel (2003), alguns fatores foram importantes para incrementar o desenvolvimento de teorias específicas de letramento, a partir de 1970; dentre eles, destacamos os seguintes: primeiramente, o movimento de educação radical desenvolvido por Paulo Freire, no final dos anos 60 e início dos anos 70, onde o conceito de letramento era o de "ler as palavras e ler o mundo", envolvendo muito mais do que um mero decodificar de signos linguísticos, mas sim a construção de uma prática social, que envolvia reflexão crítica e ação; um segundo fator de desenvolvimento dos letramentos nas novas perspectivas educacionais foi a descoberta, especialmente nos Estados Unidos, de uma crise de preparo para o enfrentamento das novas demandas econômicas e sociais, numa sociedade pósindustrial, onde os alunos depois de passar pelas instituições escolares, não davam conta das 
mudanças nas organizações e instituições que tinham de enfrentar no dia a dia; e finalmente, o desenvolvimento das perspectivas socioculturais dentro dos estudos da linguagem e das ciências sociais (GEE, 1996).

$\mathrm{Na}$ fala de P1, "então o aluno tem que levantar da carteira e ir até o quadro interativo e tocar na fruta com a caneta; aqui, fazem uma fila, levantam, correm até a lousa e batem. Então, o princípio é o mesmo, o método é o mesmo, só muda o material, que é digitado”, a comparação entre a projeção da figura no quadro interativo e o uso da caneta digital ao tocála, com um cartaz de papel colado na lousa tocado com a mão, como sendo idêntica, não leva em conta que a materialidade dos objetos e suas configurações práticas no uso da aprendizagem da linguagem, podem provocar diferentes interpretações e diferentes produções de sentido. Embora P2 declare que às vezes tem que haver uma certa adaptação de um modelo educacional para outro, em termos de material, “... e outras coisas como materiais, às vezes a gente tem que adaptar em termos de tecnologia, o que às vezes dispomos lá, como a lousa interativa, o laboratório, utilizando outros materiais como cartazes, audio em CD...”, em sua fala, não parece considerar os materiais utilizados na aprendizagem como produtores também de significação, ao declarar: "Vamos ensinar a mesma coisa em relação às quatro habilidades, o que ensinamos lá, a mesma coisa vamos ensinar aqui, procurando dar o mesmo foco na conversação, produção e tudo mais”.

Ao comentar sobre o desenvolvimento das novas mídias e suas dimensões nas práticas sociais atuais, O’Gorman (2006), declara que embora o computador seja considerado a mais influente das novas mídias utilizadas como ferramentas na educação, outros meios como televisão, vídeo-games, até mesmo telefones celulares, ainda que não façam parte integrante das práticas de sala de aula, são novas demandas que nos impelem a considerar sobre a necessidade de uma pedagogia específica dedicada aos materiais, dada sua importância. Além disso, as formas de interação modificaram-se de acordo com as novas tecnologias, o que leva a diferentes desenvolvimentos (GEE, 2003).

Castells (1996) declara que a revolução tecnológica integrou as modalidades escritas, orais e audiovisuais da comunicação, criando os hipertextos e uma metalinguagem, tudo dentro de um só sistema, e esse sistema, com a possibilidade de interação em tempo real, dentro de uma rede (network), mudou fundamentalmente o caráter da comunicação. Como comunicação e cultura moldam-se dialeticamente, produzindo e mediando sistemas de crenças, valores e códigos culturais, estes se transformaram, assim como os seus usuários, e continuarão a se transformar por conta das novas tecnologias. 
Também na entrevista com o coordenador do English Center, C1, pudemos evidenciar a mesma posição em relação à busca da homogeneidade, bem como à visão de que o aparato tecnológico diferenciado em um modelo educacional e outro, não representam diferenças significativas entre os dois modelos. C1 declara que os cursos ministrados nas unidades do English Center e nas escolas parceiras são os mesmos, característica considerada tão importante que existe um departamento acadêmico para garantir essa uniformidade em vários níveis: "Há um departamento acadêmico centralizado que garante a uniformidade tanto dos conteúdos que serão trabalhados em sala de aula quanto das dinâmicas de aula e avaliações."

Como pudemos perceber, assim como os professores P1 e P2 em suas falas sobre essa questão, C1 declara haver uniformidade entre os dois modelos de escola, em vários níveis, como conteúdos, dinâmicas de aulas e avaliações. Ao reiterar que existe um departamento que centraliza a garantia dessa uniformidade, infere-se que diferenças entre os dois modelos seriam altamente indesejáveis, pois acarretariam em perda de qualidade. Mais uma vez inferese desta fala, relacionando-a com uma anterior, na qual C1 diz "somos especialistas no ensino de inglês”, que C1 também compartilha do discurso de ineficácia do ensino de idiomas na escola de educação formal, e que a instituição que representa é a solução para esse "problema".

Ainda nesta sequência de falas, em referência ao uso dos materiais nos diferentes modelos educacionais, $\mathrm{C} 1$ declara: "O conteúdo do material é o mesmo tanto nas unidades quanto nas escolas. A adaptação acontece no recurso escolhido para trabalhar com determinado material devido às instalações disponíveis em cada escola. Por exemplo, algumas escolas têm sala de computador, outras escolas trabalham com retroprojetor." C1 parece cometer um contrassenso ao tentar garantir a uniformidade, dizendo que o conteúdo do material nos dois modelos de escolas é o mesmo, e ao mesmo tempo declarar que acontece uma adaptação no recurso escolhido, sendo que recurso e material neste contexto, têm a mesma significação.

Além disso, nesta mesma parte da sequência, podemos também inferir que $\mathrm{C} 1$, ao usar o argumento que o conteúdo é o mesmo em ambos os modelos de escolas, apesar das diferenças do recurso, no caso do material em si, não leva em consideração que a materialidade dos objetos bem como suas configurações de uso, na aprendizagem da linguagem, pode suscitar diferentes interpretações e diferentes produções de sentido. 
Essa visão nos leva a interpretar que não há uma preocupação em relação às novas propostas de ensino de idiomas dentro de uma perspectiva educacional por parte da instituição terceirizadora, como propõem os novos letramentos e multiletramentos. Esta proposta representaria uma possibilidade de adequação às novas demandas não só na tecnologia e na comunicação, mas também de todo o impacto cultural e social que ocasiona mudanças sociais, educacionais e culturais. Segundo Lankshear e Knobel (2003) os estudantes precisam de novos saberes culturais e operacionais em razão das novas linguagens que promovem o acesso a variadas práticas não só em termos de vida profissional, como também na vida cívica e nas práticas do dia a dia.

\subsubsection{A quebra da homogeneidade e a presença de conflitos: uma possibilidade para a revisão de objetivos educacionais}

Na questão da garantia da homogeneidade para uma eficácia e qualidade desejadas em relação ao ensino/aprendizagem de língua estrangeira, tomada como eixo para as análises anteriores, percebe-se que sua importância para a construção dos objetivos linguísticos desse ensino é principal e prioritária a outras possíveis demandas. Em contrapartida, em alguns dados obtidos na pesquisa, seja em entrevistas informais ou observações, pode-se inferir que também existe uma demanda para os objetivos educacionais no escopo do ensino de língua estrangeira, como propõe as teorias dos novos letramentos e dos multiletramentos.

Destaca-se a seguir, algumas observações em relação à relevância dos objetivos educacionais. Em relação aos alunos, nosso contato pessoal foi um tanto menor, porque como havia solicitado uma experiência de pesquisa apenas em nível observatório, minha participação na aula foi exclusivamente a de observadora-participante; no entanto, em algumas oportunidades pude perguntar e mesmo inferir de atitudes muito transparentes, próprias das crianças dessa idade, algumas informações sobre a percepção do olhar do aluno em relação às aulas de Inglês. Consegui informações como: “A teacher é muito legal.” / "Adoro os games, mas os meninos sempre ganham..." / "Ainda bem que acabou essa aula chata..." / "É, você esqueceu o livro só porque nunca faz tarefa, né? / "Não quero falar nada em Inglês agora, quero ver quem vai me obrigar..." / "Esse exercício de novo não..." / "Bléblé blé blé..." (brincadeiras de gozação nas repetições em coro obrigatórias); "Você não é 
minha mãe pra me mandar fazer isso..." / "Tá bom, eu saio, mas volto em cinco minutos pra assistir a aula." (aluno de $3^{\mathrm{a}}$ série ao ser colocado para fora por indisciplina).

Dessas poucas inserções, podemos interpretar dois fatos relevantes: primeiro, o espaço escolar é bastante caracterizado por situações que mostram valores, relacionamento afetivo, ideologias, preconceitos, que fazem parte da vida social do aluno como um todo; e segundo, a aula de língua estrangeira, assim como de outras disciplinas, faz parte desse espaço onde tudo isso acontece e, portanto, seria um espaço promissor para se visualizar a língua com essa variedade de enfoques que também a permeiam e não com aquela pretendida visão de ausência total de conflitos ou de heterogeneidade, pretendida nas observações dos dados até aqui interpretados.

Nas falas destacadas, exemplificamos algumas possíveis oportunidades de dimensionar os objetivos educacionais nas aulas de língua: “A teacher é muito legal”, "Ainda bem que acabou essa aula chata..." - relações de afetividade, que podem ser mais facilmente proporcionadas em um espaço dialógico onde haja a possibilidade de agência e voz, tanto da parte do aluno quanto da parte do professor; "É, você esqueceu o livro só porque nunca faz tarefa, né?..." - responsabilidade e dever; "Não quero falar nada em inglês agora, quero ver quem vai me obrigar..." e, "Você não é minha mãe pra me mandar fazer isso..." - relações de poder e dominação, ressaltando a necessidade de uma relação hierárquica não mais pautada pela dominação de forma vertical, mas muito mais num processo de relação dialógico, onde a hierarquia se distribui horizontalmente; "Adoro os games, mas os meninos sempre ganham..." - preconceito e dominação em relação aos gêneros, enfatizando a possibilidade de uma experiência reflexiva em torno de padrões e atitudes que revelam discursos sociais vigentes. Pennycook (1994), citando as bases da pedagogia crítica (GIROUX, 1988; SIMON, 1992; WEILER, 1988), descreve o espaço escolar como uma arena em potencial para transformação e mudanças, além de destacar que não só os currículos, os sistemas educacionais, mas também as práticas de sala de aula, que assumimos no nosso dia a dia, demonstram o que entendemos como língua, cultura, educação, autoridade, conhecimento ou comunicação, as quais podem ser maneiras de se desenvolver objetivos educacionais voltados à pedagogia crítica.

Pude presenciar também, algumas situações de conflito, tão comuns ao ambiente escolar, onde nota-se uma grande ênfase na autoridade do professor como líder inquestionável e absoluto. Situações como a reclamação de um aluno pela mudança de regras no meio do jogo pela professora, que foi resolvida de forma contumaz com expressões como: "mudo sim, a professora aqui sou eu." (“Who's the teacher here?” Frase várias vezes repetida). Em outra 
situação quando outra professora marcou uma prova, os alunos questionaram muito achando que não estavam preparados, ao que ela respondeu "Who's the teacher here? Vai ter prova e pronto".

Ao notarmos essas particularidades referentes à autoridade e ao relacionamento em sala de aula, citamos Gale (1996) ao comentar sobre os discursos produzidos nesse espaço. O discurso educacional tradicional mostra sua afinidade com o discurso dominante em alguns aspectos como: racionalidade, ideologia, capital cultural. Esse discurso tradicional preocupase com efetividade e com objetivos comportamentais - princípios de aprendizagem que tratam o conhecimento como algo a ser consumido nas escolas - e, estas, como meros "espaços designados a reproduzir a cultura e um conjunto de habilidades que capacitarão os estudantes a se adaptar na sociedade que os circunda" (op. cit. p. 82).

Gale (1996) ainda critica a ideologia da educação tradicional por ser conservadora, ignorando questionamentos relativos a conhecimento e poder ou entre cultura e política. $\mathrm{O}$ autor ainda aponta que uma falsa noção de objetividade acaba por limitar a educação ao instrumentalismo e a um individualismo auto-utilitário. Em sua visão, os educadores precisam preocupar-se em conhecer como tem sido individualmente moldados pelas crenças da sociedade e como essa estrutura os afeta, tanto a eles, como aos seus alunos, ou seja, como todas as suas crenças e valores, traduzidos em atitudes na sala de aula estão sendo relevantes e influenciadoras para produzir os sujeitos estudantes.

Dessa forma, práticas já descritas anteriormente como exaustivamente repetidas em todas as aulas, por fazerem parte da metodologia praticada, como atividades lúdicas motivacionais, não podem ser consideradas neutras e sem uma posição ideológica definida; a busca pela vitória e a superação do outro, a competição entre os gêneros (boys X girls, girls first), bem como a autoridade do professor não argumentada, estão por si só produzindo e reproduzindo discursos ideológicos. Corroborando esse princípio, Pérez Gómez (2001) salienta que o contexto escolar com seu caráter avaliativo, seu potencial poder de classificação e de meritocracia, que saturam e podem distorcer alguns intercâmbios e atuações sociais, e também impedem uma colaboração saudável ou solidária, baseia-se, na verdade, nas instituições da sociedade mercantil, de compra e venda generalizada, sendo essa cultura mediatizada pela escola nos seus modos de participação e nas estratégias de aprendizagem ali exercidas. Em suas palavras,

A promoção social dos valores relacionados com o individualismo se concretiza na escola em torno da concepção da aprendizagem como um fenômeno individual. A maioria dos estudantes e das escolas aceita que a aprendizagem é uma 
experiência essencialmente individual, de modo que a preocupação fundamental da atividade docente é orientar e estimular o progresso individual. Neste sentido, a aprendizagem individual e isolada apóia e reflete ao mesmo tempo uma concepção competitiva da aprendizagem, criando na sala de aula e na escola um ambiente de competitividade e falta de solidariedade (op. cit. p.170).

Muitas vezes, os próprios alunos sentem a necessidade de ir além dos objetivos estritamente acadêmicos, como por exemplo, em uma das aulas observadas (aula 10, apêndice p.167) onde durante o estabelecimento das regras do rotineiro game, um dos alunos pergunta: “E o que vamos ganhar?” Ao que o professor responde: “A vitória!” E então, alguém retruca do alto de sua sabedoria infantil: "Mas a gente precisa aprender a perder também..." Infere-se desta fala do aluno que ele espera, ou ainda, que necessita expandir as possibilidades do espaço escolar para além do conhecimento institucionalizado, representado especificamente em uma aula de inglês, por conteúdos linguísticos, pois mesmos estes, além de todas as práticas e ações realizadas em sala de aula, nunca são neutros, estando fundamentados em valores, que focalizadas por uma visão pedagógica e filosófica, nas palavras de Monte Mór (2009), podem mostrar uma preocupação

com uma percepção crítica das sociedades nas quais todos vivemos, no desenvolvimento das pessoas que interagem nestas sociedades tendo mais capacidade de fazer escolhas e decisões. (...) e o ensino de línguas estrangeiras que integra a educação fundamental, a secundária e a universitária, não podem ser vistas meramente como instrumentais, elas devem ser vistas como parte de um comprometimento educacional maior, ao assumir-se que os estudos de uma língua estrangeira podem contribuir para a educação (op. cit. p. 9).

Ainda ressaltando a perspectiva das possibilidades de objetivos além dos linguísticos nas aulas de inglês, destaco uma aula do $7^{\circ}$ ano (aula 11, apêndice p.167-168) onde o professor propõe a montagem de um game pelos próprios alunos a partir do conteúdo específico de duas unidades do livro já estudadas por eles. Divididos em grupos de quatro, os alunos devem fazer quatro perguntas utilizando a estrutura e o vocabulário das unidades citadas e posteriormente montar um tabuleiro. $\mathrm{Na}$ aula subsequente eles devem trazer papel cartolina e canetas coloridas para essa montagem. Inicialmente, os grupos estão bastante agitados com brincadeiras, atirando objetos, falando muito alto, etc. Dois alunos de um determinado grupo não conseguem adequar-se às instruções e o professor os retira da sala 
para uma conversa particular, levando seus respectivos livros. Os alunos retirados não voltam mais para aquela aula; soube depois, que estariam fazendo exercícios em algum outro ambiente da escola.

Gómez (2001) pondera que as dimensões no funcionamento organizacional das escolas na sociedade atual, marcadamente influenciada por tendências neoliberais, exibe uma constituição muito parecida com os contextos empresariais visando a eficácia de resultados e o mínimo de interferência em seu funcionamento já previsto. Em suas palavras,

Vive-se a vida acadêmica do centro escolar como uma organização objetiva, externa, acima dos indivíduos, um mecanismo asséptico que facilita a concentração nas tarefas acadêmicas e que pretende evitar a interferência de contextos pessoais ou sociais perturbadores (op. cit. p.156).

Nesta atividade específica da construção do game, por exemplo, uma simples mudança de espaço poderia abrir possibilidades de intercâmbios sociais entre os alunos, os quais poderiam ter outras experiências de aprendizagens além do proposto inicialmente. No entanto, a escola, marcada pelas tendências neoliberais, limita e distribui os espaços e os tempos para construir uma estrutura formal que visa garantir, sem interferências estranhas, o funcionamento das trocas acadêmicas já previamente estabelecidas. Assim,

a própria organização do espaço e do tempo nas aulas é regida por rotinaspadrão derivadas de uma concepção linear e mecânica do intercâmbio acadêmico, concebido como transmissão clara de conteúdos informativos e avaliação objetiva de rendimentos. Quanto menos interferências pessoais, maiores garantias de objetividade e funcionamento eficaz (op. cit. p.157).

$\mathrm{Na}$ conclusão desse fato destacado, um daqueles grupos de meninos "mais bagunceiros" do início da aula ousou fazer a seguinte pergunta como parte da elaboração do game: “Do you use toillete paper?”, o que certamente não foi validado pelo professor, alegando que este vocabulário não pertencia às unidades solicitadas. Percebe-se aqui, a preocupação em manter-se dentro dos padrões e modelos estabelecidos pelo conteúdo na restrição do vocabulário e ainda a rejeição da possibilidade de evidenciar-se um conflito na provocação irônica do grupo de alunos ao utilizar um vocabulário que pudesse confrontar valores padrões utilizáveis em uma aula de língua, perdendo-se a oportunidade de se contemplar objetivos educacionais além dos linguísticos. 


\subsection{A formação docente na parceria terceirizada: treinamento ou posicionamento crítico?}

Dentro de outro eixo de análise diante dos dados obtidos através das observações, entrevistas formais e informais, destaca-se uma questão bastante relevante nesse processo de terceirização de língua estrangeira - a formação docente na parceria terceirizada e todas as suas implicações dentro desta prática. Destaco nesta parte da análise, algumas observações interpretadas como dados, a partir de algumas conversas casuais que aconteceram imediatamente antes ou após a entrada para a observação das aulas, bem como durante os intervalos das aulas, num momento mais descontraído na sala dos professores. Durante essas oportunidades descritas acima, reportei-me aos professores que ministravam as aulas de Inglês na escola I.S.; os quatro eram funcionários da escola English Center, sem nenhum vínculo empregatício com a escola I.S. Entre eles, o que trabalhava menos tempo para a English Center tinha um ano e meio de contrato. Na escola I.S., apenas um estava desde o começo da implantação da parceria, os demais estavam há um ano e disseram que normalmente não há períodos muito longos em uma mesma escola, havendo uma mudança bastante grande de professores nas parcerias. Sobre a formação profissional de cada um, apenas um entre eles tinha a formação em Letras; os demais eram graduados respectivamente em Direito, Ciências Contábeis e Psicologia. Todos haviam tido alguma experiência com a língua estrangeira no exterior de no mínimo seis meses em algum momento da vida, ou por moradia, intercâmbio ou cursos no exterior, no entanto, nenhum deles, com exceção do professor que havia cursado Letras, tinha tido qualquer formação pedagógica profissional. Todos disseram ter sido admitidos após passarem por provas e entrevistas onde tiveram de demonstrar proficiência no idioma estrangeiro, tanto oral quanto escrita e interpretativa, mas não tiveram nenhuma restrição ao fato de nunca terem dado aula ou feito qualquer estágio em termos educacionais. Os quatro professores passaram por um treinamento intensivo onde lhes foi apresentada a metodologia da escola English Center, além de materiais, práticas e procedimentos de sala de aula. Todos davam aulas também na escola English Center para turmas regulares da escola de idiomas e consideravam ser muitíssimo diferente do que dar aulas nas escolas da parceria. Não houve um treinamento específico para ministrarem as aulas no formato de parceria com nenhum deles. Todos concordaram ao dizer que gostavam mais de dar aulas na escola English Center porque as condições de trabalho eram muito melhores: 
alunos mais interessados na aula, porque estavam lá só para aprender o idioma, portanto queriam de fato fazê-lo; materiais diversos de tecnologia de ponta, como lousa interativa em cada sala de aula, com acesso à Internet, laboratório de línguas com fones individuais, biblioteca e videoteca; respeito e motivação dos alunos muito maior, sendo alunos mais disciplinados e menos trabalhosos; uma divisão em níveis muito mais rígida, mantendo a possibilidade de se criar turmas muito mais homogêneas.

Destas conversas informais há que se destacar alguns pontos relevantes para entendermos alguns outros aspectos da terceirização do ensino de línguas estrangeiras ainda não citados, como por exemplo, a formação profissional dos professores. Levando em conta que alguns professores declararam não ter formação pedagógica, podemos supor que em relação à formação profissional, estes professores, por terem fluência no idioma, possam ter escolhido dar aulas de inglês aproveitando uma oportunidade do mercado de trabalho, ou ainda, por falta de oportunidade em relação à sua profissão de formação. Monte Mór (2006), ao demonstrar dados sobre pesquisa a respeito da escolha profissional de professores de língua estrangeira, leva-nos a crer que muitas vezes as escolhas profissionais se devem a uma série de variáveis contingentes que acabam por possibilitar uma nova carreira, a de professor. Outro aspecto a ser salientado, é o fato de que todos os professores "provaram" sua eficiência linguística, parte dela confirmada por sua experiência de linguagem no exterior. Segundo eles, esses foram aspectos fundamentais para sua profissão como professor concretizar-se. Destacamos aqui, a percepção de domínio da língua estrangeira como algo altamente desejável que nos leva à visão de língua como instrumentalidade, como algo pronto e acabado, como uma ferramenta da comunicação.

$\mathrm{Na}$ fala dos professores, percebemos a importância dada aos treinamentos intensivos para que sua profissão se concretizasse. Destaca-se que nesta visão estruturalista da língua, as metodologias dispostas em forma de treinamentos visam garantir a qualidade do ensino. Voltamos a destacar que as estratégias de treinamento, entre outras, embora tenham suas finalidades pedagógicas próprias, na visão neoliberal da pedagogia de qualidade total, são mais uma tentativa de transferir para a esfera escolar os métodos e as estratégias de controle de qualidade próprias do campo produtivo (GENTILI, 1994).

Também nas respostas dos professores às perguntas feitas nas entrevistas formais, percebe-se a visão da relevância da metodologia como base de uma prática eficaz, sequencial, uma receita pronta, que sugere uma certa segurança para o exercício de uma docência com eficácia, qualidade e modernidade. Ao ser perguntado sobre se concorda com a metodologia 
utilizada no English Center, P1 declara que sim, colocando em destaque o fato de trata-se de uma metodologia atualizada em relação às pesquisas educacionais do momento e ainda enfoca os aspectos linguísticos do ensino de língua estrangeira, ao referir-se às quatro habilidades, garantidas pela tal metodologia, nos seus dizeres: "Eu concordo porque, primeiro ela é super atualizada em relação com o que ta acontecendo no mundo, ta? É mais ou menos uma metodologia comunicativa, então a gente parte do princípio que a primeira coisa que o aluno tem que fazer é falar. Então a gente trabalha sempre com as quatro habilidades. (...) A gente vai pegar tudo o que ele aprendeu e vai botar em prática."

Muitas vezes, a ênfase na metodologia na formação docente leva os professores a uma prática que prioriza a atuação metodológica em detrimento de reflexões sobre a adequação das mesmas a determinados contextos ou momentos de aprendizagem. Monte Mór (2006, 2009), ao comentar sobre os cursos universitários para formação de professores de línguas estrangeiras ressalta que os seus conteúdos e programas durante várias décadas focalizaram metodologias, as quais de tempos em tempos se superaram; no entanto, não houve a mesma atenção para as filosofias da educação nas quais essas metodologias se fundamentam. Assim, ao serem focalizados os aspectos metodológicos e linguísticos, não há como se refletir sobre de que forma o ensino de língua estrangeira contribui para a formação do indivíduo, ao se escolher este ou aquele ensino, com bases estruturalistas, comunicativas, interacionais. Inferese que essa observação, talvez se aplique aos professores citados, pelo destaque dado à importância da metodologia e suas garantias, revelado em suas falas.

Sobre a importância dada aos treinamentos como parte de uma boa formação docente, revelada nas conversas informais já anteriormente citadas, algumas falas das entrevistas formais também corroboram essa visão. Ao relatar sobre sua preparação docente P2 explica que o English Center oferece uma espécie de palestra, em todos os semestres, onde o departamento acadêmico do instituto dispõe das mais novas teorias educacionais para serem estudadas, adaptadas e colocadas em prática na sala de aula: "O foco sempre é passar, pegar uma metodologia atualizada, o que ta acontecendo no mundo neste momento, deixar a gente a par disso pra que a gente aplique em sala de aula."

Embora a palavra treinamento ou capacitação nem tenha sido citada, infere-se que o caráter dessas palestras citadas por P2 tenha o caráter de treinamento e aperfeiçoamento de práticas, por apresentar algumas características como, periodicidade - "todo semestre a gente tem um"; "a cada seis meses a gente tem todo o..."; obrigatoriedade - "Então a gente é obrigado sempre a participar das palestras."; aplicabilidade - "deixar a gente a par disso 
pra que a gente aplique sempre em sala de aula...", "eles passam a teoria pra gente, a gente estuda e sempre tem uma aplicação disso nas (...) também.", "a gente tem que apresentar também no próprio dia, uma mini aula colocando tudo isso em prática...”; atualização - “o foco sempre é passar, pegar uma metodologia atualizada, o que ta acontecendo no mundo neste momento...".

Lembramos neste momento, que estamos tratando especificamente do fenômeno da terceirização de ensino de línguas estrangeiras, assim, conceitos e atividades praticados essencialmente pelo mundo dos negócios, são incorporados à educação a serviço da pedagogia, nas mais variadas formas. Como já tratado em capítulo anterior (dedicado essencialmente ao neoliberalismo), no discurso neoliberal a educação deixa de ser parte do campo social e político para ingressar no mercado e funcionar à sua semelhança (SILVA, 1994).

Segundo Norte (2008), em artigo sobre a capacitação profissional docente, o diretor da Lobo \& Associados Consultoria, Roberto Lobo, declara que a capacitação na educação no Brasil, ainda concentra-se mais nas áreas administrativas, mas em sua visão, ela deveria estender-se também aos professores, pois, assim como nas grandes empresas, o nível de treinamento tem relação direta com o sucesso. Em suas palavras, "cada funcionário treinado vale por dois".

Assim como no mercado empresarial há a necessidade de adaptar-se competitivamente a cada transformação ocorrida em termos de tecnologia, produção, gerenciamento, o mercado transforma-se em um ambiente de constantes mudanças, e em função disso explica-se a necessidade de constantes atualizações, treinamentos e reciclagens. Seguindo a mesma retórica de qualidade e produtividade empresarial, a educação, sob uma visão neoliberal, também encontra saída para adequar-se à competitividade de "seu mercado", nos treinamentos e capacitações pedagógicas.

A atualização ou desenvolvimento dos estudos pedagógicos na vida profissional dos docentes é considerada altamente relevante. Observa-se, no entanto, que na descrição dos professores não está prevista uma prática da reflexão sobre a atividade de ensino. Normalmente, o foco desses programas de treinamentos é o conhecimento técnico desenvolvido por ideologias instrumentalistas, que se caracterizam pela separação de concepção e execução, teoria e prática, pela padronização do conhecimento, características que possibilitam o controle, por um lado, e por outro, não prezam a valorização do trabalho crítico e intelectual entre os docentes (GIROUX, 1997). 
As racionalidades tecnocráticas e instrumentais características dos treinamentos também corroboram a redução da autonomia do professor, não só em relação ao planejamento de currículos, bem como em relação à sua implementação. Esse modelo apresenta-se como um pacote fechado, cabendo ao professor o simples papel de executar procedimentos de conteúdo e instrução prederterminados, conforme Giroux (1997) identifica a formação docente com base filosófica neoliberal. Para o autor, todo esse funcionamento parece estar a serviço de interesses relacionados à lucratividade, e se somadas a outras tradições - como discursos ideológicos de incapacidade, falta de preparo, e ainda outros fatores contingentes, como falta de condições mínimas relacionadas a disponibilidade de tempo e econômicas acabam por impedir que os professores assumam seu potencial como estudiosos e profissionais ativos e reflexivos.

Do relato do coordenador do English Center, C1, ao ser questionado a respeito da idealização dos processos de parceria ou terceirização de ensino de línguas com escolas de educação formal, infere-se em sua resposta que não há uma preocupação em relação à formação docente de seus professores em nível crítico. O coordenador demonstra em sua resposta dois pontos que se contrapõem: acessibilidade a um maior número de pessoas a um ensino de qualidade de língua estrangeira - "sendo um centro de intercâmbio cultural e o maior disseminador da língua inglesa no Brasil, é papel do English Center permitir que um número cada vez maior de pessoas tenha acesso ao que há de melhor e mais moderno no ensino da língua inglesa, somos especialistas no ensino de inglês" - garantido por sua instituição, com o fato de a parceria ser um poderoso diferencial na retenção e captação de novos alunos - "Sendo a maior rede de escolas não-franqueadas, atualmente, podemos garantir consistência na qualidade de ensino. A partir desse conceito, uma parceria com o English Center é um poderoso diferencial na retenção e captação de novos alunos”, demonstrando assim, uma nítida visão mercadológica, onde existe um cliente, que é o aluno, e o conhecimento de uma língua estrangeira, que é um bem de consumo.

Quando C1 coloca a instituição que representa como disseminador e provedor do acesso a um ensino de línguas de alta qualidade, pressupõe um papel social em uma visão de educação democrática que não condiz com o restante de sua fala, pois logo depois afirma que a parceria com a instituição que representa, dará um diferencial, que supõe competitividade, na retenção, que supõe produtividade, e na captação de novos alunos, que supõe lucratividade, objetivos claros de uma instituição de mercado.

Desta fala, interpretamos, portanto, que a visão mercadológica é a que se sobrepõe. 
Segundo Pérez Gómez (2001), o mercado reproduz e incrementa interessadamente as desigualdades de origem em termos de educação, e as exigências do mercado não se importam com valores éticos e educativos, mas se importam com a obtenção da rentabilidade a qualquer preço. Portanto, o papel social da educação não converge com os objetivos do mercado. Sendo a terceirização de língua estrangeira proposta por uma empresa, ainda que educacional, obviamente seus objetivos, tanto em referência à formação dos professores, quanto à implementação de objetivos, não prioriza uma filosofia educacional baseada em transformação e reflexão crítica.

\subsubsection{A possibilidade de uma brecha na terceirização: a agência docente?}

Um fato bastante marcante nas observações de aula durante a pesquisa trouxe à tona uma questão fundamental quando se pretende repensar práticas de ensino e modos de significação no ensino de línguas, em relação à formação docente: a agência. Seria essa uma possibilidade de abertura e transformação mesmo em um modelo tão fechado e restrito por treinamentos e técnicas institucionalizadas?

Relato a seguir uma provável evidência dessa possibilidade, através da descrição da aplicação de uma avaliação (aula 9, apêndice p.166). Observei a aplicação de uma avaliação em uma sala de $7^{\circ}$ ano; trata-se de um writing test que deve ser produzido durante os minutos presenciais de aula, sobre um tema determinado, visando o uso de estruturas e vocabulário específico já estudado, com um limite de palavras pré-estabelecido, 80 - 100 palavras. Os alunos devem optar entre dois temas: What do you think your life will be when you are 20? Write a text about your prediction, e o segundo, Your Best friend is not doing well in school. Write him/her an e-mail giving advice. O professor elucida que este teste faz parte de uma avaliação mais ampla onde cada habilidade linguística é avaliada, além de uma prova gramatical, a qual já havia sido realizada; esta destina-se a avaliar especificamente a produção escrita e serão considerados para a formação do conceito, o uso de estrutura correta e vocabulário adequado.

Em recente pesquisa sobre o assunto, Duboc (2007) identifica três problemas nas práticas avaliativas nos contextos de ensino de língua inglesa atuais, que segundo sua análise, decorrem de influências de paradigmas da modernidade. Seriam os problemas: avaliação como sinônimo de mensuração, fruto do modelo caracterizado pela experimentação e observação de fatos de forma lógica, racional e concreta; ênfase na avaliação de conteúdos 
objetivos e memorizáveis, fruto de uma concepção estruturalista saussuriana de língua como um código fixo; e utilização de provas escritas quase que essencialmente, indicada pela possibilidade de neutralidade e objetividade que essa forma de registro tenta garantir.

Segundo a fala do professor neste episódio, seriam avaliados somente esses aspectos estruturais podendo tal fato denotar uma visão que se encaixa nestes modelos acima descritos. Outras possibilidades de significação e/ou produção não são levadas em conta, ou talvez sejam até mesmo interpretadas como erro por estarem fora do modelo padronizado. Por exemplo, como o professor conceituaria se o aluno usasse uma variação linguística própria dos meios eletrônicos e própria do uso do linguajar adolescente em uma possível resposta à segunda opção, que abre espaço para tal possibilidade, dada a solicitação ser um e-mail para um amigo?

Sob a perspectiva das teorias dos Multiletramentos e do letramento crítico essa possibilidade seria perfeitamente aceitável, pois o conceito pertinente a estas teorias enfatiza justamente essas possibilidades de tipologia textual "amalgamadas" (COPE e KALANTZIS, 2000) onde os modos de representação são muito mais amplos do que a língua por si só.

Destaco ainda na continuidade deste mesmo episódio observado, o fato de que quatro alunos não conseguem chegar ao limite de palavras imposto pela atividade e estes ficam extremamente abalados com a possibilidade de entregar a avaliação fora das solicitações estipuladas, pois sabem que sua nota será prejudicada por esse fator. Mesmo depois de alguns minutos após o término da aula, após todos saírem, visto ser a última aula do período, estes quatro alunos permanecem tentando realizar a atividade a qualquer custo, num clima bastante tenso. Três deles vão, pouco a pouco, desistindo da tarefa e entregam suas atividades, parecendo bastante frustrados. No entanto, um deles, um menino que se mostra bastante nervoso, fica por último dizendo que não pode desistir e começa a chorar copiosamente. $\mathrm{O}$ professor interfere tentando consolá-lo de alguma forma dizendo o seguinte: "Calma! O máximo que vai acontecer é você ficar de recuperação...” Posteriormente, o professor relatoume que este aluno, o qual se descontrolou durante a avaliação, era um excelente aluno em todas as outras disciplinas, com conceitos sempre muito altos; além disso, mesmo em inglês, fazia todas as atividades propostas sempre com muita dedicação, muito embora não obtivesse sucesso nas atividades avaliativas formais de língua inglesa. Em havendo uma possibilidade de autonomia ou de agência ampliada para este professor, neste episódio, a avaliação desse aluno poderia ter um outro formato ou ser de outra natureza, a fim de contemplar possíveis diferenças de aptidão ou do próprio momento especial vivido por esse aluno. 
Outros aspectos pertinentes às práticas avaliativas - os contextos de pressão psicológica e emocional, as pressões burocráticas em relação à composição de conceitos e médias para uma aprovação e continuidade do curso, a auto-avaliação individual trazendo conceitos de baixa ou alta auto-estima - normalmente não são levados em conta na maioria dos planejamentos das práticas avaliativas sugeridas nas escolas formais da atualidade. No entanto, estas práticas dentro do funcionamento organizacional das escolas têm suas bases numa filosofia que se espelha nas configurações das instituições empresariais em uma sociedade neoliberal que tem por premissa a excelência, a formação instrumental e a competitividade individual (GÓMEZ, 2001). Estas propostas de organização em relação à avaliação, longe de serem neutras ou irrelevantes, podem gerar nos alunos uma visão do mundo social balizada pelas conquistas instrumentais, além disso, o êxito e o fracasso acadêmico corroboram a formação de uma identidade possivelmente frustrada, ao se restringir a significação pessoal e social deste período ao êxito acadêmico. Nas palavras de Gómez (2001),

O êxito acadêmico dá a identidade e a justificativa social a esta etapa propedêutica da vida do estudante. Quando se produz o fracasso acadêmico, por certo notavelmente alto, não existem outros mecanismos de recuperação da identidade nem da satisfação pessoal (op. cit. p.157).

Em outra aula observada, de outro professor terceirizado, pudemos interpretar em uma situação de avaliação, uma atitude relativamente diferente e de certa forma contrastante no seu propósito, em comparação com o fato acima descrito. Trata-se de uma aula pós-prova, quando os alunos ficam muito curiosos e porque não dizer ansiosos, para conhecer sua nota. Essa ansiedade é algo bastante comum na maioria das situações avaliativas de nosso sistema educacional, visto haver uma base meritocrática fundamentada na organização desse sistema. Como já citado anteriormente, muitas coisas da vida do estudante, não só em termos acadêmicos, dependem de seu sucesso ou fracasso nessas avaliações. Pudemos constatar a postura bastante comum de outros professores durante as observações quanto a isso (aula 9, apêndice p.167-168), de simplesmente anunciar a nota ou a média, em alguns casos com alguns comentários genéricos e até mesmo depreciativos, não individualizados, sobre a avaliação, prática docente bastante comum, não só no caso da terceirização, mas como prática docente em geral. Este professor, no entanto, ao iniciar sua aula, entrega a prova corrigida, feita na aula anterior, chamando cada um para ver e conversar sobre a mesma. Antes de iniciar essa atividade individual, divide a turma em duplas para que façam determinado 
exercício do livro. Assim, chama um aluno de cada vez para ver e conversar sobre a avaliação feita na aula anterior - trabalho não muito tranquilo - por ter que parar diversas vezes para atender as duplas que tentam fazer o exercício proposto e, outras vezes, interferir em alguma outra dúvida geral da classe. O professor tem que dispor de um tempo e energia especiais para esta atividade, visto que não consegue terminar a revisão individual com todos os alunos, continuando na aula subsequente.

Duboc (2007), em sua investigação sobre a avaliação nas aulas de língua inglesa, ressalta que a conceituação da avaliação como sinônimo de mensuração, fruto do modelo positivista de educação do século XIX, se evidencia na medida em que se prioriza o ato de informar aos alunos o resultado da medida de seu aproveitamento ao invés de um diálogo sobre seu desempenho nas atividades avaliativas, o que poderia se constituir num provável mecanismo de redirecionamento da prática educativa (op. cit.).

Por esta prática do diálogo sobre a avaliação com seus alunos, cremos que este professor exerceu uma quebra de paradigmas da cultura docente que impera não só nessa escola terceirizada específica, mas em grande parte das escolas formais, que pressionadas por um modelo organizacional onde os objetivos conteudistas se sobrepõem aos objetivos educacionais, não tomariam o tempo e a energia necessárias para esta atividade.

Ainda nesta mesma aula, pudemos observar outra atitude deste professor que nos fez interpretar como contraditória, a sua posição em relação à avaliação, anteriormente descrita (aula 9, apêndice p.164-165). Durante a explicação da atividade que fariam enquanto o professor estivesse atendendo individualmente para a revisão de prova, um dos alunos questiona: "O bimestre acabou. Pra quê vamos fazer isso?" Ao que ele respondeu: "O bimestre sim, mas as aulas não. Posso mudar as notas de vocês a qualquer hora..." Trata-se de uma fala bastante comum dos professores, que faz parte da cultura docente, muitas vezes utilizada como meio de coerção, mostra de poder ou mesmo atitude de limite disciplinar. Essas contradições, não raras nas práticas docentes atuais, parecem mostrar que os professores vivem uma tensão inevitável e preocupante entre as exigências de um contexto social bastante mutável, flexível, plural e cheio de incertezas, marcado por mudanças tecnológicas, diversidades culturais e outros fatores - no caso da terceirização, referentes ao mercado educacional - com as rotinas e convenções de práticas e costumes burocráticos, bastante estáticos e fixos que permeiam a organização escolar (GÓMEZ, 2001). Ademais, a própria formação individual do professor, com valores, crenças e expectativas formadoras de sua identidade, também entram em jogo quando qualquer tipo de inovação, mudança ou 
transformação é proposta. Por isso, poderíamos afirmar que a cultura docente é sempre um fator a ser considerado em toda reflexão para uma transformação educacional, com vistas a uma efetiva agência, visto que não basta apenas a compreensão intelectual dos agentes envolvidos, mas a vontade de repensar culturas anteriormente herdadas (op. cit. p.165).

Outro fato ocorrido nesta mesma aula trouxe-me outras impressões sobre a agência exercida por esse professor em sua atuação com os alunos, que diferencia sua aula das demais observadas, denotando um clima mais participativo e até mesmo mais tranquilo de um modo geral.

Enquanto conversavam sobre quanto tempo seria gasto para a atividade proposta vale ressaltar que o professor sugere 20 minutos, enquanto os alunos querem $30 \mathrm{e}$, depois de negociado, estabelece-se 25 minutos - um dos alunos, o qual pede uma explicação sobre determinado exercício, usava um fone de ouvido, o que é proibido dentro da sala pelas regras da escola, e então o professor pede que ele retire o fone. $\mathrm{O}$ aluno resiste um pouco tentando negociar, dizendo que ele está participando, fazendo o exercício proposto; ao que o professor responde: "Não, você deve tirar, porque isso não é negociável." Neste momento, um aluno que estava sentado ao meu lado, que sabia que eu estava ali como pesquisadora e anotava todas as coisas da aula, me disse: "Isso é muito importante você anotar... o teacher sempre dialoga com a gente... Por isso ele tem que ficar no outro semestre."

Esta fala, complementada com todas as atitudes, mesmo as mais sutis, observadas neste professor, denotam que apesar de estar vinculado a uma estrutura bastante estanque e reguladora, que seguia uma metodologia um tanto conservadora, não aberta a possíveis transformações, conseguiu exercer sua agência de modo a abrir espaço para diálogo, negociações e uma possível hierarquia mais horizontal com seus alunos, o que nos parecia trazer um ambiente de aprendizagem bastante favorável, demonstrando que "sempre existe uma margem de liberdade para expressar a autonomia, a resistência, a diversidade e a discrepância” (GÓMEZ, 2001).

\subsection{Análise das perspectivas atuais: a terceirização chega à escola pública.}

Embora esta pesquisa tenha tido como campo de investigação uma escola de ensino formal particular, visto ser o fenômeno da terceirização do ensino de língua estrangeira restrito a essas instituições - quando do início da mesma - passados pouco mais de três anos, hoje já podemos vislumbrar outra realidade. 
Era possível prever que, mais cedo ou mais tarde, as instituições privadas, de alguma forma, também influenciariam o ensino público em termos de língua estrangeira, pois os mesmos aspectos de deficiência e frustração evidenciados nas escolas particulares estavam também presentes nas escolas públicas, talvez até mais acentuadamente.

Além disso, outras categorias de privatização e acesso de empresas educacionais nas escolas públicas têm acontecido efetivamente, com uma certa regularidade, já há algum tempo. Em artigo publicado em 2009, sobre as parcerias entre as administrações municipais e o setor privado, é declarado que as ações governamentais com vistas a implementar essas parcerias foram iniciadas no Estado de São Paulo desde 1996 e, posteriormente em nível nacional, após a criação do Fundo de Manutenção e Desenvolvimento do Ensino Fundamental e Valorização do Magistério (FUNDEF), por meio da Emenda Constitucional n. 14/96. (Adrião, et al). Segundo o jornal Folha de São Paulo, em sua versão eletrônica do dia 30 de janeiro de 2006, há a constatação de que as prefeituras estão terceirizando a educação. Segundo a reportagem, 145 cidades brasileiras, 129 só no Estado de São Paulo (um quinto das 645 totais), passaram a usar os recursos federais destinados ao setor para pagar convênios contratados com sistemas particulares de ensino bastante conhecidos no mercado educacional brasileiro. Trata-se da aquisição de "sistemas apostilados de ensino". Citando a reportagem,

Os municípios compram um kit básico que contem apostilas para os alunos, treinamentos periódicos para professores e planejamento pedagógico. Alguns pacotes incluem avaliações da rede e fornecem ajuda pela internet. As principais empresas não divulgam seus custos, mas eles variam de R\$ 145 a R\$ 260 por aluno/ano. As aulas ocorrem em escolas da rede municipal e os docentes são pagos pelas prefeituras. (op. cit.)

Essas parcerias são autorizadas por lei e embora muitos especialistas contestem o fato do dinheiro público ser repassado ao setor privado, nem sempre garantindo uma melhora na qualidade de ensino, é justamente por este fator - a qualidade do ensino - que muitos pais, alunos e até mesmo professores mostram-se favoráveis às parcerias. Em capítulo anterior desta pesquisa, ao citarmos o pano de fundo da terceirização contextualizado pelas forças neoliberais da sociedade capitalista como uma força hegemônica que propõe uma ordem social criada a partir do livre-mercado, o discurso da qualidade total tem sido o mote principal para justificar a transposição dos objetivos empresariais do mercado, para a educação (GENTILI, 1999).

Há poucos meses atrás, durante a parte final desta pesquisa, foi noticiada a assinatura de um decreto (apêndice p.169-170) pelo Governador de São Paulo, José Serra, estabelecendo 
a possibilidade de deslocar as disciplinas de língua estrangeira da escola pública para os Centros de Estudos de Línguas (CELs) e destes para instituições privadas. Isso aconteceu em 10 de setembro de 2009, tendo sua publicação no Diário Oficial em 11 de setembro de 2009.

Embora no trecho inicial do referido decreto 54.758 (texto na íntegra no anexo deste trabalho) haja a citação específica da língua espanhola "considerando a oferta obrigatória pela escola e de matrícula facultativa para o ensino da língua espanhola, a partir de 2010...”, os $\operatorname{artigos} 4^{\circ}$ e $5^{\circ}$ deixam estabelecido que as línguas estrangeiras da grade curricular do ensino fundamental e médio podem passar a ser cursadas nos Centros de Línguas (CELs), e se a capacidade destes estiver esgotada em vista de grande procura, segundo o texto da lei, "a Secretaria da Educação poderá contar com instituições públicas e privadas que tenham por finalidade o ensino de idiomas, devidamente credenciadas para esse fim, observando as disposições legais pertinentes."

Chega-se assim, à terceirização das línguas estrangeiras também na escola pública, não só do espanhol, mas também podendo acontecer com o inglês e outras línguas que façam ou que venham a fazer parte do currículo.

Em relação ao espanhol, o fato de os CELs atualmente serem bastante limitados em relação à possibilidade de abrangência de possível procura maciça de matrículas, aliado à obrigatoriedade da aplicação da lei 11.161, que estabelece a oferta do espanhol no ensino médio a partir de 2010 nas escolas da rede estadual, pode ter como consequência a não realização de concursos para a disciplina de língua espanhola. Além disso, o seu oferecimento fora do planejamento escolar no formato de terceirização, abre a possibilidade para que cargos que poderiam ser ocupados por professores com estabilidade e direitos trabalhistas, não sejam criados, sendo concedidos a empresas educacionais privadas, onde muitas vezes, as condições trabalhistas não estão garantidas.

Ademais, em relação à língua inglesa, interpretando o artigo $4^{\circ}$ que estabelece que a língua estrangeira do currículo da grade escolar poderá ser efetuada pelos CELs - na grande maioria das escolas, a língua inglesa - e do artigo $5^{\circ}$ que estabelece que estando esgotada a capacidade dos CELs em atender a demanda de matrículas, empresas educacionais, poderão absorver esses alunos, autoriza-se, estabelece-se, também na escola pública, a terceirização do ensino de língua inglesa pelos institutos de idiomas.

Vemos que a argumentação produzida pelo texto do decreto - "...considerando as inovações introduzidas no currículo...", "considerando a importância de se assegurar aos alunos da rede pública estadual a oportunidade de desenvolver e ampliar novas formas de 
expressão”; “...considerando as necessidades de se propiciar aos alunos instrumentos de acesso às novas tecnologias e ao mercado de trabalho que exige cada vez mais o domínio de um idioma estrangeiro...", gera um discurso positivo de implementação de melhora, modernidade e sucesso, que serão enfim possíveis fora do espaço público, visto como ineficaz e arcaico, contrapondo-se à imagem de eficácia e modernidade das empresas privadas.

Segundo Santomé (2003), o sucesso dessas argumentações das ações neoliberais fica bastante visível perante a aceitação de amplos setores da sociedade em relação a essas práticas de terceirização. Sobre o decreto em São Paulo, é sabido, por exemplo, que a APEESP (Associação Paulista dos Professores do Estado de São Paulo) manifestou-se solicitando audiência com a Secretaria da Educação do Estado (www.apeesp.com.br), uma atitude seguida recentemente pela APLIESP, que também solicitou audiência (WWW.apliesp.org.br). Outras ações isoladas de contestação, não obtiveram espaço na grande mídia.

Ainda em breve análise do trecho inicial do decreto, evidencia-se o forte apelo não só do caráter instrumental do ensino de línguas, como também a proposição de objetivos meramente reprodutivistas de acesso às tecnologias e ao mercado de trabalho. Infere-se que, nessa visão, as instituições de ensino teriam seu valor e necessidade apenas e na medida em que ofereçam uma formação adequada para esse mercado. Santomé (2003) argumenta:

O conceito de educação como bem de consumo implica promover uma mentalidade consumista em seus usuários e usuárias: professores e alunos. Ele estimula considerar o trabalho escolar e as ofertas de formação do ponto de vista de consumidores e consumidoras, isto é, de seu valor de troca no mercado, dos benefícios que pode produzir esta ou aquela disciplina, especialidade ou título. A instituição escolar só é considerada imprescindível como recurso para obter no futuro, importantes benefícios privados, para enriquecer individualmente (op. cit. p. 32).

Outros objetivos educacionais também importantes que subjazem ao ensino de língua estrangeira, bem como outras disciplinas, já colocados em evidência neste trabalho, os quais visam a formação de um cidadão crítico e atuante em sua sociedade não foram contemplados no texto do decreto. A única citação que poderia sugerir uma interpretação dentro dessa visão educacional e formadora do ensino de línguas limita-se ainda ao plano individual, quando propõe a "oportunidade de desenvolver e ampliar novas formas de expressão" ao aluno. Embora importante essa visão não é suficiente para uma educação linguística que pretenda o desenvolvimento de cidadãos que vivem em uma sociedade em transformação, onde a 
diversidade, a pluralidade e a autonomia são conceitos em expansão. Limitar o ensino de língua estrangeira a essa visão instrumental e individual pode representar uma barreira à implementação de uma nova perspectiva educacional contemplada pelas teorias dos novos letramentos e multiletramentos.

\section{CONSIDERAÇÕES FINAIS}

"E viveram felizes para sempre...", o começo de "uma história meio ao contrário" protagonizada por mim como professora de inglês, que assim como inúmeros outros professores, sentia de alguma forma uma insatisfação com os resultados de meu trabalho docente, vivi a experiência da terceirização, que certamente marcou-me, não só fazendo-me ter a vontade de pesquisar esse fenômeno, como também influenciando-me na interpretação de cada observação e análise ao construir esta pesquisa.

Sob esse locus de enunciação, no capítulo 1, foram focalizadas como tem sido as práticas do ensino de língua inglesa bem como os novos projetos desse ensino, sob a perspectiva de uma proposta educacional e não apenas linguística, baseada nas teorias dos novos letramentos e multiletramentos (GEE, 1990; COPE e KALANTZIS, 1996). Essas teorias, baseadas numa concepção de língua construída por práticas sociais situadas historicamente e localmente e, também levando em conta mudanças epistemológicas do próprio conhecimento em função das transformações que a globalização e a s tecnologias digitais ocasionaram, parecem adequar-se ao novo aprendiz, vendo-o como um agente na construção de seu próprio conhecimento. Nessa visão do conhecimento construído, em termos de ensino e aprendizagem de línguas, as heterogeneidades e os conflitos emergem como novas possibilidades de interpretação, onde para o aprendiz, além de uma atuação crítica e não reprodutiva diante dos sistemas, abre-se a possibilidade de produção e de transformação.

No entanto, percebe-se que esses objetivos educacionais formadores, não tem sido contemplados no que diz respeito ao ensino de línguas, não só nas práticas terceirizadas objeto desta pesquisa - mas principalmente nelas, devido ao seu caráter padronizador e homogeneizante. Ao considerarmos esse fenômeno educacional no capítulo 2, consideramos o contexto econômico no qual se insere. Fazendo uma contextualização político-social do fenômeno da terceirização dentro do campo educacional, destacamos o neoliberalismo como 
pano de fundo, que como uma doutrina econômica homogeneizante, estabeleceu o mercado como uma nova instituição reconhecida, o qual passou a atuar e regular outras instituições sociais, dentre estas, a escola. Destacou-se nesse estudo, como pressupostos da terceirização, a descentralização produtiva tendo em vista a garantia da excelência de qualidade e manutenção da rentabilidade. Esses objetivos tipicamente mercadológicos foram transpostos para o campo educacional não só retoricamente, mas também de forma pragmática. Exemplos dessa tendência foram explicitados nas análises dos materiais de propaganda da terceirização do ensino de línguas, dispostos na mídia.

No capítulo 3, as análises realizadas a partir dos instrumentos utilizados para a pesquisa - observação de aulas terceirizadas, entrevistas formais e informais com os participantes das práticas de terceirização - apontavam para duas questões principais: as dificuldades para se lidar com a heterogeneidade numa escola de educação formal e a formação docente nas parcerias terceirizadas. As evidências pela busca da homogeneidade foram observadas não apenas nas metodologias praticadas pelos professores terceirizados com exercícios de repetição baseados em modelos, formatação padronizada das aulas, configuração do processo de avaliação padronizada, material didático, divisão das turmas em níveis linguísticos, como também em suas práticas de aula focadas em evitar todo tipo de conflito, fossem estes de caráter disciplinar, de relacionamento ou pedagógicos.

Outra questão apontada pelas análises foi a formação docente nas parcerias terceirizadas. Destacou-se não apenas a irrelevância da formação pedagógica, como também a ênfase dada pelo instituto de idiomas terceirizador nos treinamentos e atualizações periódicos realizados com o corpo docente. Notou-se que esses treinamentos mantinham um caráter focado nas metodologias atualizadas em termos de práticas docentes, sem enfoque a possíveis questionamentos ou posições reflexivas.

Apesar disso, para ambas as questões, vislumbraram-se possibilidades de brechas de atuação a partir de atitudes discrepantes dos modelos padronizados por parte de um ou outro professor, em determinados momentos. Essa atitude de agência por parte do professor denota que, ainda que ele esteja vinculado a uma estrutura padronizadora, se houver a intenção de questionamento e de uma reflexão crítica, poderão ser abertos espaços para diálogos, negociações e prováveis transformações. 
A análise da prática da terceirização no ensino de língua estrangeira e de suas respectivas práticas educacionais no contexto da educação formal, que foi objetivo desta investigação, mostrou que essa prática não é compatível às expectativas desse ensino na escola de educação formal, se esta pretende, a partir de objetivos educacionais formadores, basear sua atuação social na formação de cidadãos que sejam participantes críticos e transformadores e não apenas reprodutores.

Esperamos que esta pesquisa possa contribuir para a informação e para a formação daqueles que de alguma forma estejam interessados em escolher ou rever possíveis alternativas para a educação linguística numa perspectiva educacional que leve em conta a formação do aprendiz. Visto que a prática da terceirização no ensino de línguas acaba de transpor os limites do ensino particular, atingindo também setores da escola pública, como salientado no final do capítulo 3, esperamos que estes estudos possam sugerir novas reflexões sobre essa questão. 


\section{REFERÊNCIAS BIBLIOGRÁFICAS}

- AMATO NETO, J. Reestruturação industrial, terceirização e redes de subcontratação. Revista de Administração RAE, FGV, v.35, n.2, abr/jun.1995.

- ANDERSON, P. Pós-Neoliberalismo: As Políticas Sociais e o Estado Democrático. Orgs. Emir Sader, Pablo Gentili. Rio de Janeiro: Paz e Terra, 1995.

- ANDRÉ, M. E. D. A. de. Etnografia da prática escolar. 10ª Ed. Campinas: Papirus, 2003.

- ANDRIOLI, A. I. As políticas educacionais no contexto do neoliberalismo. In Espaço Acadêmico, ano II, n. 13, jun. 2002.

- BARTON, D. (1994) Literacy: an introduction to the ecology of written language, Oxford, Blackwell, 1994.

- BAUMAN, Z. Globalização: As conseqüências humanas (Globalization: The human consequences. New York: Columbia University Press) Traduzido por Marcus Penchel. Jorge Zahar, 1998.

- BRASIL, Secretaria de Educação Básica. Parâmetros Curriculares Nacionais: terceiro e quarto ciclos do ensino fundamental: língua estrangeira. Brasília: Ministério da Educação, 1998. 
- BRASIL, Secretaria de Educação Básica. Orientações Curriculares para o ensino médio: linguagens, códigos e suas tecnologias - conhecimentos de línguas estrangeiras. Brasília: Ministério da Educação, 2006.

- BUEnO, S. F. Pedagogia sem sujeito: Qualidade Total e Neoliberalismo na Educação. São Paulo: Annablume/Fapesp, 2003.

- CARMAGNANI, A. M. G. Ser e não-ser: os dispositivos de subjetivação do sujeitoprofessor no discurso da mídia. Seminário internacional Michel Foucault: Perspectivas. 21 a 24 de setembro de 2004. Simpósio temático n. ${ }^{\circ}$ 4: Michel Foucault, o sujeito, o discurso e a identidade.

- COATSWORTH, J. H. Globalization, growth and welfare in History. In Globalization, culture and education in the new millennium. Berkeley and Los Angeles: University of California Press, 2004, p. 38-55.

- COPE, B.; KALANTZIS, M. Multiliteracies: literacy learning and the design of social futures. London: Routledge, 2000.

- CORACINI, M. J. Autonomia, poder e identidade na sala de aula. In: Linguística e Educação: Gramática, Discurso e Ensino. Oliveira e Passegi (org.), 2000.

- _ _ _ A escamoteação da heterogeneidade. O Desejo da Teoria e a Contingência da Prática. São Paulo: Mercado das Letras, 1995.

- CORdaro, E. M. e BARÃO, F. Humus consultoria. Disponível em www.humus.com.br Acesso em maio de 2008.

- COSCARElli, C. V. \& RIBEIRO, A. E. Letramento digital. Aspectos sociais e possibilidades pedagógicas. Belo Horizonte: Ed. Autêntica, 2005. 
- DUBOC, A. P. M. A questão da avaliação da aprendizagem de língua inglesa segundo as teorias dos novos letramentos. Dissertação de Mestrado. São Paulo: Universidade de São Paulo, 2007.

- FONSECA, C. Quando cada caso não é um caso. Pesquisa etnográfica e educação. Trabalho apresentado na XXI reunião anula da ANPED, Caxambu, setembro de 1998.

- FAIRCLOUGH, N. Language and power. London and New York: Longman, 1989.

- FOUCAULT, M. Microfísica do poder. Rio de Janeiro: Graal, 1979.

- GADOTTI, M. Educação e Globalização Neoliberal: um olhar a partir da América Latina. In Educação e linguagem. Ano 9, n. 13, p. 22-46, jan.- jun. 2006.

- GALE, X. L. Teachers, discourses and authority in the postmodern composition classroom. Albany: State University of New York Press, 1996.

- GEE, J. P. Situated language and learning. New York \& London, Routledge, 2004.

- Social linguistics and literacies: Ideology in discourses. 2 ed. London: Taylor \& Francis, 1996.

- GEERTZ, C. La Interpretacion de las culturas: Descripción densa: hacia una teoria interpretativa de La cultura. México: Gelisa, 1987.

- GENTILI, P. A. A. \& SILVA, T. T. Neoliberalismo, qualidade total e educação. Petrópolis: Vozes, 1999.

- _ _ Neoliberalismo e educação: manual do usuário. In: SILVA, T.T. da, GENTILI, P. (orgs). Escola S.A.: quem ganha e quem perde no mercado educacional do neoliberalismo. Brasília: CNTE. 1996.

- GIROUX, H. The Giroux reader. Boulder, London: Paradigm Publishers, 2006. 
- _ Challenging neoliberalism's New World Order, Education after Abu Graib, Border crossings, 2. Ed. New York and London: Routledge, 2005.

- _ Language and intercultural communication. n.6, p.2, 2004.

- _ Os professores como intelectuais: rumo a uma pedagogia crítica da aprendizagem. Porto Alegre: Ed. Artes Médicas, 1997.

- GÓMEZ, A. I. P. A cultura escolar na sociedade neoliberal Porto Alegre: Artmed Editora, 2001.

- GRIGOLETTO, M. Seminário Internacional Michel Foucault: Perspectivas. 21 a 24 de setembro de 2004. Simpósio temático $n^{\circ}$ 4: Michel Foucault: O sujeito, o discurso e a identidade.

- HALL, S. The Work of Representation. In: Representation. Cultural representation and cultural signifying practices. London/ Thousand Oaks/ New Delhi: Sage/ Open University, 1997.

- JORDÃO, C. M. English as a foreign language, globalization and conceptual questioning. Globalization, societies and education, 7:1,95 - $107-2009$.

- JULIA, D. A cultura escolar como objeto histórico. Revista brasileira de história da educação, São Paulo: n.1, p.9-43, jan/jun 2001.

- KOIKE, B. Idioma terceirizado. Escola de inglês dá aula dentro dos colégios e reduz custo. Jornal online Valor Econômico. 27 de maio de 2008. Ano 9, no 2014. Disponível em http://www.valoronline.com.br/Default.aspx?scrollX=0\&scrollY=1467

- KRESS, G. Literacy in the new media age. New York, USA: Routledge, 2003.

- LANKSHEAR C. e KNOBEL M. New literacies: Changing Knowledge and Classroom Learning. Buckinghan, UK: Open University Press, 2003. 
- LANKSHEAR, C. Frameworks and workframes: Literacy Policies and New Order. Boulder, Colorado: Westview Press, 1996.

- LOMBARDI, J. C., SAVIANI, D. NASCIMENTO, M. I. (orgs.) Campinas, S.P: Graf. FE:HistEDBR, 2006. CD-ROM.

- MARTINEZ, J. Z. Uma leitura sobre concepções de linguagem e educação profissional de língua inglesa. Dissertação de Mestrado. Curitiba: Universidade Federal do Paraná, 2007.

- MONTE MÓR, W. Foreign languages teaching, education and the new literacies studies: expanding views in Gonçalves, G. R. et all (orgs), New challenges in language and literature. Belo Horizonte: FALE/UFMG, 2009.

- _ _ L L Línguas estrangeiras, educação e os novos letramentos. Texto, memória e diferença cultural. Guarapuava: Ed. Unicentro, 2007.

- _ _ A Mediação entre a teoria e a prática no ensino de línguas estrangeiras. São Paulo, Revista Crop n. 11, p. 347-361, 2006.

- MORIN, E. A cabeça bem feita. Rio de Janeiro: Ed. Bertrand Brasil, 2000.

- MUSPRATT, S., LUKE A. \& FREEBODY, P. Constructing critical literacies. St Leonards, Hampton Press, 1997.

- NOGUEIRA, M. A.; NOGUEIRA, C. M. M. Bourdieu e a educação. $2^{\mathrm{a}}$ Ed. Belo Horizonte: Autêntica, 2006.

- O'GORMAN, M. Nonsense and Play: The Figure/Ground Shift in New Media Discourse In: E-Crit: digital media, critical theory and the humanities, 2006. 
- OLIVEIRA, E. P. A importância de se ensinar/aprender inglês no ensino médio da rede pública estadual: o discurso de pais e alunos. Dissertação de Mestrado. São Paulo: Universidade de São Paulo, 2005.

- PENNYCOOK, A. The cultural politics of English as an international language. New York: Longman, 1994.

- Critical Applied Linguistics: critical an introduction. Mahwah, New Jersey, London: Lawrence Erlbaum, 2001.

- RAJAgOPAlAN, K. Por uma Linguística crítica: linguagem, identidade e a questão ética. São Paulo, SP: Parábola Editorial, 2003.

- _. O grande desafio: aprender a dominar a língua inglesa sem ser dominado por ela. In: GIMENEZ, T. at al (orgs.) Perspectivas educacionais e o ensino de inglês na escola pública. Pelotas: EDUCAT, 2005, p. 37-47.

- REVUZ, C. A língua estrangeira entre o desejo de um outro lugar e o risco do exílio. In: Linguagem e identidade - Elementos para uma discussão no campo aplicado. SIGNORINI, I. (org.) Campinas, SP: Mercado das Letras, 1998.

- RIBEIRO JUNIOR, J. O que é Positivismo. $2^{\text {a }}$ Ed. São Paulo, SP: Brasiliense, 1982.

- RODRIGUES, A. T. Neoliberalismo: Gênese, Retórica e Prática. In: Filosofia, sociedade e educação. São Paulo (1): p. 193-226, 1997.

- SANTOMÉ, J. T. A educação em tempos de neoliberalismo. Porto Alegre: Artmed 2003.

- SANTOS, B. de S. Neoliberal repression to people's utopian imagination. ALAJ América Latina em Movimento, s.d. [on line]. Acesso: março de 2009. Disponível em: http://alainet.org/active24603 
- SILVA, F. L. et al. Conciliação, neoliberalismo e educação. São Paulo: Annablume/Fundação Unesp, 1996.

$\cdot$ F. L. et al. Neoliberalismo, Qualidade e Educação. Petrópolis, Vozes. 1994.

- SOARES, L. T. Os custos sociais do ajuste neoliberal na América Latina. São Paulo: Cortez Editora, 2000.

- SOARES, M. Letramento, um tema em três gêneros. Belo Horizonte: Ed.2005

- SUÁREZ-OROZCO, M.M. Learning in the global era. Berbeley, Los Angeles and London: University of California Press, 2007.

- SUÁREZ-OROZCO, M.M. \& QIN-HILLIARD, D.B. Globalization, culture and education in the new millenium. Berbeley and Los Angeles: University of California Press, 2004.

- TÓFOLI, D. Prefeituras de São Paulo terceirizam a educação. Folha Online. 30 de janeiro de 2006. Acesso em: janeiro de 2010. Disponível em: http://www1.folha.uol.com.br/folha/educacao/ult305u18312.shtml

- UECHI, S. Inglês: disciplina-problema no ensino fundamental e médio? Dissertação de Mestrado. São Paulo: Universidade de São Paulo, 2006.

- USHER R. and EDWARDS R. Postmodernism, Postmodernity and the Postmodern Moment. In: Post modern and education. London and New York: 1994.

Sites pesquisados:

http://www.histedbr.fae.unicamp.br/navegando/glossario/verb_c_neoliberalismo1.htm (Inep: http://www.inep.gov.br/). Acesso em 17 de janeiro de 2009. 
http://educacao.uol.com.br/ultnot/2009/03/30/ult105u7807.jhtm Acesso em 31 de março de 2009.

Sindicato dos Professores do Ensino Oficial do Estado de São Paulo em http://educacao.uol.com.br/ultnot/2009/03/30/ult105u7807.jhtm Acesso em 31 de março de 2009.

Neoliberalismo e Educação: manual do usuário. Disponível em: http://firgoa.usc.es/drupal/node/3036. Acesso em 2 de junho de 2006.

http://educacao.uol.com.br/sociologia/politica-dos-blocos.jhtm Acesso em 30/12/2009 


\section{APÊNDICES}

\section{Transcrição da entrevista com professores}

\section{Entrevista 1}

$\mathrm{P} 1=$ Professor $1 \quad \mathrm{E}=$ entrevistador

E: A primeira coisa que eu queria que você falasse são informações pessoais do tipo, seu nome, sua formação, sua formação acadêmica, o que você estudou, quanto tempo você trabalha no English Center quanto tempo você trabalha aqui no I.S. com o English Center.

P1: Meu nome é.., eu sou professor de Português e Inglês, eu sou formada em Letras, também sou formada em publicidade, trabalho no English Center por quatro anos, TRE anos e... vai fazer quatro anos agora no fim do ano e o mesmo tempo no I.S. Eu já trabalhei nove anos em outras escolas também tenho como formação os exames de ..., o TKT que é o exame de profe ... para ser professor de Cambridge, e que mais? Já trabalhei no I.S. por três anos também, o mesmo tempo que eu trabalhei no English Center eu tô trabalhando no I.S.

E: Então quando você entrou pro English Center já tinha a parceria aqui no I.S...

P1: Já tinha a parceria aqui no I.S., ela já tava acontecendo há algum tempo.

E: Me fala uma coisa, em relação à parceria, você trabalha só aqui no I.S. na parceria, ou você trabalha também no English Center com as aulas da instituição normal?

P1: No English Center? Nos dois lugares. Trabalho aqui no I.S. nas segundas e quartas de manhã e trabalho também só no Emglish Center. 
E: Em relação a níveis, aqui eu sei que você trabalha com o nível Fundamental I e Fundamental II que seria de $5^{\mathrm{a}}$ a $8^{\mathrm{a}}$ ou de $6^{\circ}$ ao $9^{\circ}$, né? E lá no English Center, você trabalha com que níveis?

P1: Com todos; no English Center a gente trabalha com crianças também, igual a gente trabalha aqui, até com adultos também, adolescentes, adultos, todo mundo.

E: Você tem turmas esse ano, você está trabalhando com adolescentes?

P1: Sim, tem. Esse semestre eu tô com todos, tô com crianças também na filial, tô com adolescentes e também estou com adultos.

E: Tá OK. E você acha que existe diferença em relação às duas categorias de ensino? $\mathrm{O}$ English Center lá, no instituto de idiomas e aqui na parceria? Se você acha que existem, quais são elas?

P1: Não... não é o caso , na questão do ensino lá não tem diferença, o que tem diferença é a disposição da sala que é assim, então por exemplo, no English Center a gente tem a sala um pouquinho menor que essa e as carteiras são colocadas em U. Aqui aparentemente as salas não são, as carteiras não são colocadas em U, mas a gente tenta fazer quando dá, quando a disposição da sala permite, a gente coloca a carteira em U. Então a diferença é um pouco física, na questão do ensino não existe diferença; o que a gente faz lá, a gente faz aqui da mesma maneira. O método que a gente aplica lá a gente também aplica aqui. O que difere é que, por exemplo, no English Center nós temos um quadro interativo...

E: Então em termos de material...

P1: É mais a parte física, mas a gente adapta pra trazer pra cá também, então, por exemplo, o que nós faríamos no quadro interativo, por exemplo, a gente mostra um slide de alguma coisa que eles estão aprendendo, por exemplo, crianças, eles aprendem vocabulário; vou te dar um exemplo específico, então eles estão aprendendo as cores, então lá no English Center a gente mostra, a gente projeta, né, um slide, seria um slide .....

E: A lousa interativa, eu já vi... Você pode utilizar por cima...

P1: Isso... A caneta... Aqui como a gente não tem o quadro interativo, o que a gente faz? A gente traz os slides para os cartões, com a mesma imagem que a gente projetaria lá, coloca na 
lousa e a gente faz a mesma atividade, por exemplo, ele sai correndo e bate na frutinha, por exemplo.

E: Tá bom...

P1: Então é a mesma coisa, é como eu te falei... só a parte física, mas a aula seria a mesma, então o aluno tem que levantar da carteira e ir até o quadro interativo e tocar na fruta com a caneta; aqui, fazem uma fila, levantam, correm até a lousa e batem. Então, o princípio é o mesmo, o método é o mesmo, só muda o material que é digitado.

E: Certo. Em termos de número de alunos, você disse que existe uma diferença também ou não ?

P1: Não, número de alunos não. Por isso eu te falei até no começo que eu não tenho aula agora, porque não precisa dividir em três, né? No English Center a gente também trabalha com 20 alunos no máximo em sala de aula, e aqui é a mesma coisa, ou a gente divide, quando vai inscrever o número, a gente divide em três, ou em dois, as turmas.

E: E essa divisão é feita de que forma? É por homogeneidade de nível?

P1: Essa divisão eu não posso te falar muito, porque eu não participo dela. Essa divisão é feita com os professores das, os ex-professores das turmas e a gerência do English Center em parceria com a diretoria daqui do I.S. Então ela senta, e fazem a divisão conforme o colégio, o I.S. quer e o English Center sugere... de professores, e eu não participei ainda dessa divisão; só peguei a turma depois de dividida.

E: Mas você supõe que seja por nível, nível linguístico?

P1: Não, não. A turma começa, eles começam desde o comecinho aqui, ninguém sabe nada... Então a divisão eu acredito que seja por se portar... como tem demais, turma A, turma B, acredito que pega um pouquinho de cada, pra fazer uma mistura, não por nível.

E: Não existe um teste, uma avaliação de nível lingüístico para que algum que esteja no advanced ...

P1: Aí sim. Isso que eu te falei é quando eles entram, então seria o primeiro nível do English Center que é o Start. Então ele é dividido, como ainda ninguém tem a experiência, né, ele é dividido dessa maneira, contudo, quando tem as turmas mais avançadas, aí... ah essa já sabe 
um pouquinho de Inglês então eles fazem uma aplicação de nível... então, os pais falam,olha... porque os pais são informados, né, pelo English Center.... então, quando eles vão se informar tem um... a maioria das vezes... ela já passa pra gente... ele já sabe Inglês, então a gente faz uma classificação de nível que é a mesma classificação que é feita no English Center e aí se o aluno já tiver passado daquele nível, porque também assim, as crianças, quando elas estão aprendendo Inglês, tem que acompanhar o que elas aprendem em Português, a gente não pode ir além disso. Então se elas estão sendo alfabetizadas, não pode colocar a criança num nível que já tenha escrita, por exemplo. Então às vezes, tem que levar tudo isso em consideração. Então dependendo do nível dela, mesmo que ela esteja um pouquinho à frente no Inglês, mas ela não sabe escrever ainda, ela tem que ver cada coisa no seu tempo; isso as crianças. Os mais velhos, que já sabem escrever e tudo, a gente faz essa classificação de nível e aí se a cri, o aluno não tiver... pra... ele é encaixado em outra turma de acordo com o nível de inglês dele e no Fundamental II também. A gente tem casos de, por exemplo, o aluno... durante o ano, alguns saem num nível, outros saem em outro, porque já tinham alguma experiência em Inglês.

E: Parece que você me falou que dá aula há bastante tempo, né? Assim na sua carreira como professora, como educadora em termos pedagógicos, de metodologia, filosofia educacional, você tem algum suporte, no English Center ou em outro lugar, ou você busca isso pessoalmente?

P1: Não, a gente tem. O English Center mesmo oferece pra gente todo suporte. O Emglish Center todo semestre, ele tem um, eh, XXXX... são palestras, tá? Então todo semestre a gente tem que se atualizar. Então, como a gente trabalha no English Center com, desde crianças até adultos, então a cada seis meses a gente tem todo o.... que a gente chama, que a gente vai lá e tem todas as palestras atualizadoras pra tudo. Pra desde curso de metodologia pra adulto, pra adolescente, pra criança também. Então a gente é obrigado sempre a participar das palestras.

E: E nessas palestras vocês basicamente estudam ou, fazem o quê? É assim, em relação à metodologia do English Center, ou pesquisas novas, alguma coisa assim, ou material... Qual é o foco?

P1: O foco sempre é passar, pegar uma metodologia atualizada, o que tá acontecendo no mundo neste momento, deixar a gente a par disso pra que a gente aplique sempre em sala de aula... atualmente, então por exemplo, o departamento acadêmico do English Center faz toda 
essa pesquisa, então quando a gente vai na XXXX, nas seções, nas palestras, eles passam a teoria pra gente, a gente estuda e sempre tem uma aplicação disso nas XXXX também. Então a gente também tem que fazer, como a gente fala... a gente tem que apresentar também no próprio dia, uma mini aula colocando tudo isso em prática eles também passam a lista de leitura pra gente pesquisar, pra tirar alguma dúvida e a gente tem o departamento acadêmico sempre à nossa disposição . Mesmo fora dessas palestras, qualquer dúvida que a gente tiver a gente entra em contato com eles...

E: Com a coordenadora ou o coordenador, etc...

P1: Isso, isso. E aí o... learning são as crianças, é tudo divididinho, a gente contata o departamento e eles dão um suporte pra gente.

E: Em termos de metodologia, agora a sua opinião pessoal: você concorda com a a metodologia que o English Center utiliza e qual metodologia, assim, nas suas palavras você...

P1: Eu não vou dar nome porque...

E; Não, nas suas palavras...

P1: Eu concordo porque, primeiro ela é super atualizada em relação com o que ta acontecendo no mundo, ta? É mais ou menos uma metodologia comunicativa, então a gente parte do princípio que a primeira coisa que o aluno tem que fazer é falar. Então a gente trabalha sempre com as quatro habilidades... O conjunto dessas quatro habilidades forma a... O hábito é trabalhar com... as quatro habilidades a fala, a escrita, a leitura e o listening . Então a gente sempre em toda a aula, a gente trabalha com essas quatro coisas. Então, basicamente o aluno, ele vai ouvir, vai falar, vai entender, vai... produzir, e a gente vai pegar tudo o que ele aprendeu e vai botar em prática .

E: OK. Aqui nessa escola, que é uma escola formal, né, não é um instituto de idiomas, o currículo é variado e tem o Inglês entre as outras matérias, e sobre os parâmetros curriculares nacionais, você conhece, os parâmetros, né?

P1: Conheço...

E: Então, existe alguma adaptação ou algum estudo em relação à essa metodologia que o English Center utiliza sobre os parâmetros? 
P1: Sim, a gente tem que cobrir os Pcns, a gente tem que cobrir aquele bloquinho, que a gente chama, em cada semestre, em cada ano, os alunos tem que conhecer isso. Junto com isso, outros aspectos, o English Center sempre fez isso...... Então o que a gente faz? A gente tem que pelo menos ensinar o mínimo estipulado pelo MEC, que é de cobrir o bloquinho do MEC. Mas a gente ta além disso já, a gente consegue ensinar o mínimo e o máximo.

E: E em termos filosóficos, os Pcns trazem algumas coisas relacionadas à visão crítica, visão de mundo, e isso de alguma forma, você acha que a metodologia do English Center, ela se adapta a esse plano que os parâmetros curriculares trazem?

P1: Eu acredito que sim, eu tive né, os PCNs, por causa da Licenciatura que eu tive que tirar pra poder lecionar no colégio, eu tive, tive todos esses PCNs, eu tive que estudar na faculdade e como eu tô acostumada a trabalhar no I.S., consequentemente, eu acredito que sim, tudo está sendo feito direitinho. Tá atendendo, mesmo a parte filosófica, como você falou, eu acredito que tá tudo direitinho.

E: No caso, você acha que houve uma adaptação do que é feito no English Center, que pelo que você me falou é absolutamente igual, o método que se faz lá se faz aqui. Então não houve uma adaptação em relação ...

P1: Não à matéria em si, adaptação que há, é lógico, é toda aquela parte de colégio mesmo, então aqui além de ensinar Inglês a gente também faz esse lado...... mas além de ensinar o Inglês aqui tem toda aquela outra parte de educação; então o aluno também que ta aqui ta sendo educado, então como a Rosa citou na reunião, a gente encontra um aluno gritando no corredor, a gente também, é uma situação que a gente não tem lá, a gente não tem corredor, a gente tem as salas isoladas; então aqui essa parte, a gente adapta essa parte da educação, da formação do indivíduo, então quando a gente vê os alunos no corredor, a gente também tem que estar preocupada com a educação deles. _ Olha, você não pode gritar no corredor, você ta num colégio. Você tem que aprender tudo, então, tem toda essa parte que a gente não tem no English Center que é a adaptação que a gente faz aqui, por isso é que a gente é do English Center, mas a gente também é I.S. É essa adaptação que a gente faz, além do que o currículo mesmo do aluno.

E: Agora bem pessoal, você gosta mais de dar aula lá ou aqui? 
P1: Os dois. (rsrs) Eu tinha um sonho muito grande quando eu era aluna, né, como eu te falei eu sou formada em Publicidade. Eu me formei em Publicidade primeiro, depois eu fiz Letras, porque enquanto eu estava na faculdade de Publicidade, eu comecei a lecionar, a dar aula de Inglês, e eu me apaixonei. Eu tinha essa idéia, porque eu sempre tive muita facilidade por línguas, isso é um caso pessoal meu, né, por isso eu tô te contando. Eu sempre tive uma facilidade, e eu via quando eu era pequena que as aulas de Inglês da escola não eram legais, né. Os professores ficavam preocupados com o livro e mandavam... do livro fazer e muitas daquelas pessoas, eu ajudava muitos deles, porque eles não entendiam nada. Então a professora não falava Inglês na sala de aula, a professora não, a gente tinha que fazer $\mathrm{o}$ exercício do livro. E eu tinha um sonho, né, que era entrar numa escola pra lecionar, pra tentar, como eu ensinava meus colegas. Falava: _ Pôxa vida, eu to ensinando meus colegas e olha a aula que eu estou tendo, né? _ enquanto eu era aluna. Então eu falei, ah quando eu tiver oportunidade, um dia eu quero entrar numa sala de aula de escola e mostrar pros alunos que eles também podem aprender. Que não é essa coisa de que em escola ninguém aprende nada.

E: Você já trabalhou em escola pública?

P1: Não. Só assisti aula do estágio, de estágio que eu tinha que fazer em colégio público. Eu ... tipo assim, trabalhar no I.S. pra mim é parte de um sonho, que é aquele sonho que eu tive de entrar numa sala de aula e dar o que eu tive que achei que foi muito. Eu tinha facilidade porque meu pai é, por coisas pessoais, meu pai me ensinava e então isso pra mim é um sonho, tá aqui pra mim é parte de um sonho. E o English Center é a ferramenta que me dá, pra eu dar essa aula e eu consigo aplicá-la aqui. Pra mim os dois lugares são bons.

E: E aqui seria então como você falou mais parte do seu sonho porque aqui os alunos são mais...

P1: É que é assim, lá todo mundo que quer aprender Inglês, né, colocam um anúncio de uma escola de Inglês. Aqui, aqui, isso que eu queria mudar, mudar esse conceito de que precisa e você não consegue aprender Inglês na escola, eu queria mudar isso. Eu vi isso acontecer com os meus colegas e era parte do meu sonho, mostrar que isso é possível.

E: Na sua opinião pessoal, por que aconteceu a parceria no I.S.?

P1: Olha, quando eu cheguei já acontecia, então eu não sei quais eram as razões ... mas na minha opinião, tem muito a ver com isso que eu te falei de mudar esse conceito de que na 
escola não aprende Inglês. Se você for analisar aí fora, muita gente termina a oita...,ou o nono ano, ou o colegial e eles realmente não, eles estão preparados às vezes pra ler alguma coisa ou fazer algum exercício de leitura, mas ele não está preparado pra vida ele não tá preparado pra fazer uma entrevista do trabalho em Inglês, não tá preparado pra viajar, e não precisar da ajuda de nin... de alguém. Então eu acho que o I.S., por ser um colégio que tá preocupado com a formação dos alunos, teve essa percepção de, na minha opinião, não sei, de fazer isso acontecer. ... Eu acho que o I.S. percebeu que enquanto nas outras matérias os alunos já estavam bem, o Inglês precisava sair disso e também que eles conseguissem chegar no nono ano além ou aquém daquilo que é esperado de escola. Então por isso é que eu acho, eu acho, é aquilo que eu te falei, como professora aqui, como eles estavam preocupados com a formação dos alunos, eles devem ter procurado oferecer, justamente aquilo que era o meu sonho... Que eu percebia com uma turma, então, acho que foi isso. Em relação ao English Center poder participar disso, né, também não sei como era, mas pelo que eu sei, poder participar disso,oferecer a chance pro alunos chegarem mais preparados pro mercado, porque hoje em dia, você não basta só falar uma língua, são duas; são especializados também na área de espanhol, passar pros alunos as duas coisas. E não é raro, acredito em Português você faz uma prova de Inglês. Atualmente, os cargos bons, as entrevistas já são feitas em Inglês, então, não adianta o aluno estar preparado com um textinho, ou perguntas pra responder por e-mail. Então, tem que falar. Vai ter que falar e apresentar as coisas pessoais dele, das experiências dele...

E: Ok. Muito bom P1. Obrigada.

P1: Imagina, obrigada você.

\section{Entrevista 2}

$\mathrm{P} 2=$ Professor $2 \quad \mathrm{E}=$ Entrevistadora

E: Primeiro gostaria de saber seu nome, formação acadêmica, graduação.

P2: Meu nome é P2 e eu sou formado em Letras, Português/ Inglês, sou formado pela USP, ah, tenho portanto a graduação, sou bacharel, e tô terminando a Licenciatura agora, tô fazendo a minha última matéria, Metodologia, também na USP, na FEUSP. Ah, além dessa formação na graduação, eu tenho alguns certificados que são oferecidos pela Universidade de Cambridge, no que se refere ao ensino da Língua Inglesa como língua estrangeira e como 
segunda língua. Ah, esses certificados, enfim, um deles chama-se ISELT e significa In Service Certificate of English Language Teaching, ah... Cetificado de Ensino de Inglês como Língua Estrangeira na Prática, então são, é um certificado que tem dois módulos, um de língua e outro de metodologia, que nada mais é do que a preparação de aulas, a apresentação dessas aulas , a análise do ponto de vista acadêmico realmente,porque eles, eh... esses trabalhos refletem leituras e reflexão, em cima da aula apresentada. Enfim, e objetivos traçados pra ah... o funcionamento dessa aula. São certificados bem complexos, porque eles envolvem um ano e meio de estudo, é como se fosse uma iniciação científica, mas...

E: E você fez esses estudos aqui no Brasil...

P2: Isso, aqui no Brasil, os trabalhos são redigidos, eu tenho um tutor

\section{E: Pelo English Center...}

P2: Pelo English Center, porque ele é representante oficial da Universidade de Cambridge aqui, mas não necessariamente tem a ver com o English Center; são trabalhos que eu tenho um tutor, que a Universidade de Cambridge denomina uma pessoa que acompanha minha preparação de aula, uma vez que a aula está preparada, eu tenho a autorização pra apresentála, as aulas são reais, e então eu apresentei, se eu seguir meu plano de aula perfeitamente, se eu atingi meus objetivos claros, a aula vale, se eu não atingi, vou ter que preparar tudo de novo. Ah..., e essa pessoa ta ali presente, me avaliando em todos os passos. Ah..., depois dessa apresentação, eu tenho uma reunião com esse tutor, que ele vai observar dois aspectos que eu pequei na aula: então, meu pecado foi, eu não corrigi adequadamente os alunos, então eu preciso trabalhar com a correção, de que maneira? Eu sou obrigado a assistir outros dois professores, ah..., como a gente dá aula no English Center, a gente assiste lá, ah..., esses professores têm que ter essa qualificação já, ah..., anterior, e com base nesses professores eu vou fazer uma análise crítica da minha postura em sala de aula e do que eu aprendi. A partir desta outra discussão eu vou redigir um, uma monografia, ah... de duas mil palavras, ah... de modo que ela reflita o processo de aprendizado. Ah... e no final, ah..., esse trabalho, todos esses trabalhos juntos, os relatórios dessas conversas que eu tive com esse tutor, são enviados pra Cambridge, aí eles vão passar pelo crivo de uma avaliação e no final das contas, eu passo ou não.

E: É um TCC, praticamente... 
P2: Isso... Isso, mas ele é direcionado ao ensino de Inglês como língua estrangeira ah..., o que é bem interessante, porque ele leva em consideração aspectos sociais, você tem que fazer um, uma, transcrever o perfil daquela classe, ah..., idade, classe social, horário que estuda, isso acaba fazendo diferença no plano de aula, eh, uma das aulas foi, inclusive uma das aulas aqui do I.S. ah..., justamente pra ponderar justamente que não há diferença da minha aula dentro da instituição chamada English Center e dentro da minha aula dentro da instituição I.S., já que as escolas estão, são parceiras ah..., nessa questão.

E: Já que você tocou nesse assunto, você está aqui no I.S. o mesmo tempo que você está no English Center ou no English Center, você veio pra cá antes, ou lá antes, como foi essa história?

P2: Tá. Primeiro eu tabalhei no English Center, eu tô lá há cinco anos. No I.S. eu estou há dois. Então o English Center acabou fechando esse tipo de parceria com o I.S. onde as aulas de Inglês, portanto intracurriculares, são oferecidas pelos professores do English Center, ah..., e esse caminho tem sido em paralelo, ah..., desde que eu saiba que há esse projeto do English Center intracurricular nas escolas. Há umas outras escolas que têm o English Center extracurricular, que é assim, tá fora, ah..., não segue os Parâmetros Curriculares Nacionais, enfim. Esse não, esse a gente segue. Ah..., uma vez que a gente está em parceria com a escola.

E: O que significa pra você seguir os Parâmetros Curriculares Nacionais, o que você quer dizer com isso?

P2: É, é cumprir com o, o papel da escola, da, do I.S. em si, né? Ah..., geralmente as escolas de ensino de língua estrangeira elas acabam seguindo um próprio planejamento; eu conheço algumas. Entretanto o, o PCN nacional, PCN nacional é pleonasmo, né... o nosso PCN, ele acaba se pautando em regras, principalmente pra parte do ensino de idiomas de língua estrangeira que vem de uma padronização educacional ah..., européia. Ah..., então a gente, ah..., o nosso PCN se baseia naquela documentação, ah..., então o que eu consigo te afirmar é, o English Center segue esse P..., esses parâmetros, formando não somente um falante, mas um cidadão, que usa aquela linguagem de maneira efetiva, eficaz, ah..., na sua relação (pausa) com as demais pessoas, com outras sociedades, ah..., então é assim que eu entendo, ah..., se utilizar, a aplicação do PCN. Exatamente. 
E: E você acha que a metodologia utilizada pelo English Center, aqui no I.S., e na escola, no English Center mesmo, lá no instituto de idiomas, ela tem diferença, ou não?

P2: Não. Não. Em termos práticos não. Ah..., o que pode se ver de imediato, é que no English Center a gente tem um apa..., aparato tecnológico disponível, mas que não me deixa, ah..., que não perde nada na aula que acontece aqui, afinal de contas, antes de termos o tal do quadro interativo, dávamos a aula com quadro branco e canetão.

E: E a metodologia era a mesma.

P2: A metodologia é a mesma. Não há diferença nenhuma. Agimos de maneira sócioconstrutivista na montagem da aula, na... aplicação das atividades, todas elas, ah..., têm por objetivo uma situação real, ah..., pertinente à vida do aluno, daí a importância da gente fazer aquele curso, que eu acabei fazendo, né... ah..., o curso anterior de perceber horário, turma, perfil, idade, questões sócio-econômicas, se pertinentes, enfim. Então, isso me ajuda a planejar melhor a aula e a atingir os mesmos objetivos, fazendo adaptações que eventualmente sejam necessárias ah... pra sala de aula.

E: Você falou em adaptações, você acha que elas são necessárias, e se são necessárias essas adaptações, em que nível elas são feitas? Você...

P2: Por exemplo, as aulas aqui no I.S., geralmente, os alunos estão enfileirados, no English Center nós trabalhamos com a sala em formato de U. Aqui, só quando dá, ou quando a disposição da sala permite. E outras coisas como materiais, às vezes a gente tem que adaptar em termos de tecnologia, o que às vezes dispomos lá, como a lousa interativa, o laboratório, utilizando outros materiais como cartazes, áudio em CD...

E: Então a adaptação é feita em termos de materais... e não há nenhuma mudança em termos de objetivos?

P2: Não, de jeito nenhum. Vamos ensinar a mesma coisa em relação às quatro habilidades, o que ensinamos lá, a mesma coisa vamos ensinar aqui, procurando dar o mesmo foco na conversação, produção e tudo mais.

E: Muito obrigada por sua colaboração.

P2: Foi um prazer. 


\section{Entrevista escrita com a coordenadora do English Center}

1- Há quanto tempo o English Center oferece esse tipo de serviço?

As parcerias entre o EnglishCenter e as escolas iniciaram em 1997 com cursos extracurriculares. Foi a partir de mudanças na LDB, em 1996, que as escolas puderam terceirizar as aulas de língua estrangeira. A primeira parceria intracurricular surgiu em 2003.

2- Por que esse processo de parcerias com escolas formais foi idealizado pelo English Center?

Sendo um centro de intercâmbio cultural e a maior disseminadora da língua inglesa no Brasil, é papel do English Center permitir que um número cada vez maior de pessoas tenha acesso ao que há de melhor e mais moderno no ensino da língua inglesa; somos especialistas no ensino de inglês. Sendo a maior rede de escolas não-franqueadas, atualmente, podemos garantir consistência na qualidade de ensino. A partir desse conceito, uma parceria como English Center é um poderoso diferencial na retenção e captação de novos alunos.

3- Existe alguma diferença entre os cursos ministrados nas unidades do English Center e nas escolas parceiras?

Os cursos ministrados nas unidades do English Center e nas escolas parceiras são os mesmos. Há um Departamento Acadêmico centralizado que garante a uniformidade tanto dos conteúdos que serão trabalhados em sala de aula quanto das dinâmicas de aula e avaliações.

4- Existe alguma diferença de material usado nas unidades do English Center e nas escolas parceiras, como uma adaptação?

O conteúdo do material é o mesmo tanto nas unidades quanto nas escolas. A adaptação acontece no recurso escolhido para trabalhar com determinado material devido às instalações disponíveis em cada escola. Por exemplo: algumas escolas têm salas de aula com computador, outras escolas trabalham com retroprojetor.

5- Como são escolhidos os professores que dão aulas na parceria?

Os professores escolhidos são especializados no ensino de crianças e adolescentes. São profissionais que estão em constante aperfeiçoamento e atualização através de encontros semestrais, cursos e workshops realizados pelo próprio English Center.

6- Existe alguma classificação em níveis? Se sim, como é feita?

Fazemos as classificações de nível a partir do $5^{\circ}$ ano do Ensino Fundamental 1, da mesma maneira que recomendamos que aqueles que procuram uma das unidades do English Center também o façam. Há 3 componentes nas classificações de nível: produção oral, reconhecimento de estruturas gramaticais e lexicais e produção escrita. Os professores iniciam 
com uma entrevista em português e, em seguida, percebendo o histórico de cada aluno, continuam essa entrevista em inglês. Depois, pedem os exercícios de reconhecimento e a produção escrita.

7- Você considera a parceria um sucesso? Por quê?

Considero as parcerias um sucesso, sim. A primeira razão se refere aos benefícios que o English Center pode oferecer aos alunos das escolas parceiras. Além da qualidade do ensino, todos os alunos das escolas parceiras podem usufruir dos eventos culturais oferecidos - fator importantíssimo ao se aprender outra língua: conhecer também a sua cultura. Há também o acesso a recursos tecnológicos de ponta que tornam o estudo mais interessante e dinâmico.

\section{Observações de Aulas}

\section{Aula 1 (Nível: $3^{a}$ série ou $2^{\circ}$ ano)}

Há poucos alunos na sala porque é pré-feriado (10 alunos). A professora trouxe uma porção de adesivos para as meninas, conforme havia prometido.

A sala é disposta em grupos. Eles estão separados em grupos de meninas e meninos, segundo informação, por conta deles.

A professora se dirige aos alunos em grande parte do tempo, em inglês. Quando eles estão agitados, ela fala em português pedindo silêncio e atenção. Farão uma atividade colorindo os ponteiros de um relógio. Ela questiona sobre como se pergunta horas em inglês. Eles repetem várias vezes em vários tons, como se fosse uma brincadeira. A sala é dividida para um game, em meninos e meninas. Eles escolhem um nome para cada time.

Há um garoto cego na classe, ele senta-se bem separado dos demais, mas na hora do jogo ele se junta com um grupo de meninos.

A professora explica as regras do jogo, usando várias frases em inglês. Repassa algumas estruturas relativas a horas, ensina sobre quarter past, porque ainda não haviam aprendido , explicando a novidade em detalhes na lousa e repassando o que já haviam aprendido.

A professora dá alguns exemplos bem detalhados em português, de coisas que eles não estão entendendo. Ela repete a mesma frase, de uma determinada estrutura, várias vezes, e eles a seguem em coro. Neste momento, a classe toda parece estar bem envolvida. A professora interrompe tudo e pede cooperação, pois vai explicar como será o jogo para o aluno cego, particularmente. Ela começa um treino para que eles mostrem as horas nos relógios, faz isso em português. As meninas seguem essa instrução, treinando, mas os meninos, não fazem. 
Durante esse treino, alguém sugere um horário diferente e a professora interrompe dizendo: “ Isso a gente ainda não aprendeu...”

Alguns teimam em continuar pintando o relógio e a professora diz que no final haverá tempo para isso.

A professora deixa as frases de exemplo na lousa para ajudá-los; depois de um tempo, os meninos começam a treinar também, mas não se concentram muito. Há um aluno que é especialmente inquieto, o tempo todo. Nesse momento, as meninas se dispersam um pouco.

Antes de iniciarem o jogo, tirando par ou ímpar, ela pede que os meninos cooperem com o amigo cego, ajudando-o durante o jogo.

Um dos meninos reclama de uma das regras do jogo. Nesse momento a professora tira ponto da equipe porque diz que não pode haver reclamação, pois as regras já estão firmadas desde o começo do ano. Depois disso, todos aceitam bem.

O jogo consta de montar o relógio com uma determinada hora e mostrá-lo para o time adversário que deverá responder em inglês. Em determinado momento, quando a equipe dos meninos perde um ponto, um dos alunos fica muito irritado com o grupo, sai e senta-se no fundo da classe sozinho. A professora diz que então ele fará outra coisa, indicando alguns exercícios para ele fazer. Ele fica muito bravo, batendo as coisas na carteira e o seguinte diálogo se estabelece: "Você faz isso na sua casa com a sua mãe? Ao que o aluno responde: “Às vezes, sim. "Mas aqui eu não te dou liberdade pra isso." - diz a professora.

O jogo continua e as meninas estão na frente. A professora chama a atenção para que o grupo faça o aluno cego participar.

Em determinado momento, há um problema sobre a contagem dos pontos, as meninas reclamam muito e a professora decide o que fazer dizendo: "Eu sou a teacher aqui, eu decido. Can I be the teacher?"

As meninas acabam vencendo e um dos meninos diz: "Esse jogo é muito bobo, mesmo..."

Agora todos voltam a pintar os ponteiros do relógio e enquanto isso a professora troca alguns adesivos com algumas meninas. Alguns garotos não querem pintar tudo e a professora insiste para que pintem por completo.

Depois de algum tempo, a maioria dos meninos saem porque é o momento do intervalo, no entanto, as meninas continuam pintando e trocando figurinhas com a professora. A professora solicita para que o último dos meninos ajude o colega cego a descer as escadas para ir ao pátio, o que ele atende prontamente, levando o colega pela mão. A professora tem que pedir para que as meninas saiam, pois estão muito entretidas com os adesivos. 
Foram 50 minutos de aula.

\section{AULA $2\left(1^{\mathrm{a}}\right.$ série ou $2^{\circ}$ ano)}

Os alunos estão voltando do intervalo e já começam a pegar o seu material. A professora pede para que sejam rápidos ao entrarem e saírem, pois alguns, apesar de serem daquela turma, assistirão aula em outra sala por causa da divisão por níveis linguísticos, que já começa desde cedo. Enquanto ela prepara o aparelho de som, material carregado por todos os professores do nível fundamental em todas as aulas, os alunos pegam seus livros e ela pergunta fazendo um mix português- inglês; "Você like ou você love eggs?" E os alunos participam bem contando suas opiniões.

Estão aprendendo uma música que usa vocabulário sobre comida e cantam com bastante animação. Eles também participam repetindo algumas estruturas em inglês. A professora demonstra nesse momento que está incomodada com o barulho externo que está atrapalhando muito.

Voltam a cantar a música e a professora solicita para que eles sigam cantando e apontando com os dedos na leitura do livro, enquanto cantam. Ela percorre a sala para ver se estão mesmo seguindo a leitura enquanto cantam. Ela então solicita que traduzam o que cantaram e quando um aluno erra, outra aluna o corrige.

Alguns querem pintar, mas a professora não permite. Passam a fazer um exercício de repetição com a letra da música, repetindo em vários tons. A professora solicita novamente que enquanto repetem, mostrem com o dedo a leitura do texto da música no livro. Os alunos participam das repetições. Ela abaixa o som e deixa que eles cantem mais sozinhos.

Nesse momento, solicita, em português, que pintem as figuras das frutas que estão no livro. Enquanto isso,vai perguntando: “What colors are pears?”, etc... No livro, estão escritas as cores que eles devem pintar.

Ela aproveita algumas oportunidades passando entre os alunos para que eles falem algumas palavras em inglês, como por exemplo: "Preciso de um apontador; quem tem um sharpner?"

Em determinado momento, ao precisar de uma cor, um aluno pede em inglês: "Quem tem um red?"

Enquanto pintam, a professora sugere que poderiam escutar mais músicas e fazem uma votação rápida para ver qual preferem.

Um dos alunos, curioso com a minha presença, pergunta para a professora quem eu sou, e ela sugere que ele pergunte a mim. E ele me pergunta: "Por que você está aqui?" Eu respondo 
que estou fazendo uma pesquisa aprendendo sobre as aulas de inglês. E ele me diz: "Você vai ser professora de Inglês quando você crescer?"

Ela solicita que falem as palavras que estão usando em suas conversas, em inglês, como cores e objetos que já conhecem. Depois de algum tempo, passam a fazer uma atividade de recorte no livro. Trata-se de uma história que eles devem colocar em ordem cronológica; parece que eles já conhecem a história.

Durante essa aula, a professora quase não escreve na lousa; escreveu apenas duas palavras que falaram ao acaso, que estavam fora do contexto da lição do livro.

Fez uma brincadeira para que limpassem o chão após os recortes, dizendo que ia sair e assim que voltasse queria ver tudo limpinho. Ela saiu, fechou a porta e voltou rapidamente e apenas alguns alunos, de forma bem ágil, se empenharam em tirar o lixo do chão, mas a grande parte ignorou.

Nesse momento, acontece bastante agitação, pois eles vão grampear a historinha com a professora, além disso, a outra parte da turma que teve aula em outra sala, já está à porta, querendo entrar.

Depois disso, a professora diz que vai colocar a historinha no CD para que ouçam e sigam no livrinho que formaram, mas erra o track e atrasa um pouco mais; depois de alguns minutos da história encontrada, alguns prestam atenção, mas muitos estão dispersos fazendo outras coisas. Então a professora desiste da história, pois os outros alunos que chegaram estão agitados do lado de fora querendo entrar.

\section{AULA 3 (Nível $4^{\text {a }}$ série ou $5^{\circ}$ ano)}

A professora me apresenta como pesquisadora, pois eles estavam muito curiosos sobre quem eu era e qual era meu nome.

Logo após, ela segue em tom enérgico, dizendo que vai falar tudo em português por tratar-se de um assunto muito sério, e começa a falar sobre falta de responsabilidade em não trazer o material; diz ser uma regra do colégio ter todo o material e fora isso, atrapalha não tê-lo nas aulas.

Hoje, quatro estavam sem material, mas ela diz que é reincidente e que isso tem sido constante com essa turma.

Os alunos não ouvem passivamente, retrucam bastante, se justificam de variadas formas e um acaba brigando com a amiga por dizer que ela estava mentindo sobre sua desculpa. A 
professora se irrita e diz ser muito feio intrometer-se em assuntos dos outros e faz com que ele peça desculpas para a amiga, o que ele faz, depois de reclamar um pouco.

A professora começa uma checagem de exercícios do livro que eram tarefa de casa, mas os alunos dizem que aquele já estava corrigido. Passam para o próximo, corrigindo oralmente, com a participação de alguns. Muitos não fizeram determinado exercício e então ela pede para copiarem em folha separada para entregar.

Durante a correção, ela corrige bastante a pronúncia, elicitando a repetição dos outros; sempre que há um erro, ela para na hora e corrige-o. Embora muitos estejam sem o livro, permanecem quietos durante a correção, a qual tem um foco bem gramatical. Ela usa a lousa, colocando em detalhes, abreviações de formas verbais, a conjugação do verbo have got. Eles vão falando as formas verbais para cada pronome, de maneira bem desanimada, como se estivessem "tirando um sarro" da situação.

Vez ou outra há uma pausa para uma bronca, a qual é feita sempre em português. Durante a correção, os alunos acertam a maioria dos exercícios e quando erram, a professora dirige-se aos amigos para que corrijam onde estava o erro.

Após a correção, iniciam um jogo que consta em jogar uma bolinha e a pessoa que pegá-la, deverá falar uma frase com have got e passar a bolinha; a professora vai solicitando frases afirmativas ou negativas.

Apesar de terem certa dificuldade, pois tem que usar a estrutura falando uma frase sem nenhum contexto, a maioria se envolve e solicita que eles joguem a bolinha para quem não participou ainda, para garantir que ninguém fique sem falar.

Houve alguns casos em que um aluno caçoou de outro por algum erro e a professora interferiu, para que fossem pedidas desculpas. Depois de certa insistência, o aluno obedeceu. - "Apologize! Say you are sorry!"

A professora pergunta se todos entenderam a estrutura do verbo ensinado e eles garantem que sim. Um dos alunos mais agitados diz: "Dava pra dormir nessa aula...” E ronca audivelmente. Um aluno diz que a aula já acabou e a professora retruca, dizendo que só acaba quando ela sair da sala. O aluno volta a retrucar algumas coisas e depois diz, "I'm sorry, teacher."

Ela introduz a forma interrogativa do verbo have got na lousa, com short answers também. Faz várias perguntas oralmente para que respondam com respostas curtas.É a professora quem delimita quem fala e quando fala, de forma bem explícita.

Ao marca uma prova, eles reclamam muito e então e a professora passa a falar sobre responsabilidade de forma bastante incisiva. Quando a aula termina e a professora regular da 
turma chega, ela reclama para ela, da falta de respeito, preguiça e esquecimento dos livros, ainda em frente à sala.

\section{AULA 4 (Nível: $7^{\mathrm{a}}$ série ou $8^{\circ}$ ano)}

Quando cheguei, a aula já havia começado, pois demorei um pouco a encontrar a sala indicada. Os alunos estavam um pouco tumultuados porque estavam muito preocupadas com uma próxima avaliação e questionavam a professora para que ela lhes desse alguns exercícios de revisão antes da comentada prova; no entanto, ela tentava explicar-lhes que revisão não fazia parte de seus planos.

A professora havia solicitado a presença de outra professora de inglês do grupo terceirizado que estava ali aquela manhã, a qual já havia sido professora dessa turma anteriormente, e pelo que pude entender, tinha fama de mais "enérgica" para tentar resolver a situação com eles. Ela define que não haverá revisão, pois diz que revisão é todo dia, prestando atenção na aula. Depois disso, declara: “Qualquer problema, é falar comigo. É assim e pronto. Ficou claro?" Essa professora deixa a sala.

A professora da turma começa sua aula comentando com eles, em inglês, onde passarão o próximo feriado, se vão viajar, para onde, etc. Durante as respostas, já vai corrigindo algumas coisas erradas e insiste que o façam completamente em inglês. Um dos alunos questionados não quer responder em inglês de jeito nenhum; a professora insiste muito, ele resiste e diz que não vai falar em inglês. Ela diz: "Ou sai, vai para a sala da XXXX (professora mais enérgica citada acima), ou fica e participa da aula.” A professora resolve então dar uma segunda chance e ele fica, mas não fala em inglês.

Outros alunos solicitados a responder têm bastante dificuldades para se expressar, ao que a professora pede que os outros ajudem na construção da frase/resposta. A partir daí, o clima começa a ficar melhor. Começam a conversar de forma mais descontraída sobre o que farão no feriado, que é no próximo final de semana.

Com algumas perguntas da professora, o tema da conversa passa para esportes. A professora vai então para a lousa e começa a escrever muitos nomes de esportes que os alunos vão dizendo numa tempestade de ideias. A frase básica é “Are you good at...” Nesse momento, os meninos participam muito mais do que as meninas. Enquanto isso, aquele aluno que ia sair, porque não queria responder em inglês, não participa de nada e fica conversando e brincando no fundo da sala com uma colega. 
Pareceu-me que eles já tinham trabalhado o vocabulário do assunto. Muitas vezes, a conversa ficava entre dois alunos e a professora, apenas, e os outros se dispersavam totalmente. Começam a fazer alguns exercícios orais de repetição, ao que alguns alunos participam de modo a fazer chacotas sobre o jeito de falar. A professora pede que sejam mais naturais ao repetir. Esse exercício é feito tanto com o grupo todo, quanto individualmente. Estão usando as estruturas do futuro com vocabulário sobre "Sporting life". Alguns alunos confundem as estruturas, com o uso do gerúndio, assim ela vai à lousa e revê os usos do “ing”. Eles perguntam se terão que saber tudo isso na prova, pois estão muito preocupados com a avaliação. Um aluno declara: "nem tudo é difícil aqui... mas chega na hora da prova..."

Nesse momento, a professora introduz em sua fala a pergunta "have you ever...", que eles já viram estruturalmente na aula passada. A turma é dividida em dupla e eles começam a repetir pequenos diálogos que têm as direções na lousa; alguns e hesitam, mas acabam fazendo. Há uma música moderna ao fundo. A professora vai passando de dupla em dupla para ouvi-los, interferindo algumas vezes. Nesse momento, ela apaga as direções da lousa e os alunos reclamam muito.

Depois disso, eles fazem um listening onde devem descobrir quais os esportes que determinado personagem já fez. Não estão utilizando nenhum tipo de texto escrito, nem o livro. Ela vai parando a gravação e dando algumas dicas. Ao final, pergunta se há dúvidas em relação ao tema dos esportes, que foi trabalhado.

Antes de saírem, a professora comenta sobre a matéria da prova, definindo páginas e assuntos gramaticais do livro que aparecerão na avaliação. Os assuntos salientados eram em sua maioria temas gramaticais e algum vocabulário também.

\section{AULA 5 (Nível: $3^{\text {a }}$ série ou $2^{\circ}$ ano)}

A classe está bastante agitada. Apesar de serem apenas dezesseis alunos, um dos meninos fala muito alto, grita e agita as demais crianças. A aula começa com cumprimentos em inglês e também com alguns comandos para que todos peguem seus livros.

A primeira atividade é uma música que eles devem seguir indicando a letra no livro, enquanto ouvem. A seguir, fazem um exercício de listening e repetição; depois a professora vai parando em alguns pedaços da música, que eles então interpretam, dizendo o que significa em português. Houve algumas perguntas relacionadas à diferenças fonéticas, como por exemplo: "Por que cantou fan se está escrito fun? A professora tenta explicar dando outros exemplos de palavras. 
A professora usa português na maioria do tempo, mesclando algum vocabulário em inglês, já conhecido por eles, especialmente o vocabulário da lição em que se encontram no livro. Alguns se interessam pela minha presença e perguntam rapidamente quem eu sou. Começam uma atividade no livro da qual a maioria participa, mas aquele aluno agitado continua a brincar e distrair seus colegas e não faz a atividade.

Em determinado momento, um aluno pergunta: "O que quer dizer are old?" Ao que a professora responde em seguida: “A gente ainda não estudou isso, tem muitas palavras aí que você não conhece.” Em seguida, fazem uma atividade no livro com colagem de adesivos de figurs referentes à música que cantaram no início da aula.

A próxima atividade, também realizada no livro, é explicada com detalhes pela professora com exemplos pessoais, com o tema summer holidays. Depois, fazem uma atividade de match e writting e a professora explica que usarão essas palavras para conversarem em diálogos. Percebo que muitos não entenderam exatamente o que era para fazer, pois a professora, que é bastante calma, não repete os comandos e fala em tom baixo também. A maioria dos alunos então, explica entre si; eles vão perguntando um ao outro para conseguirem fazer a atividade, no entanto, alguns desistem e ficam brincando de outras coisas.

A professora passa a explicar sobre a atividade/jogo escolhendo uma dupla para usar como exemplo, no entanto, a maioria não dá muita atenção, mas mesmo assim, ela continua. Nesse momento, um aluno se aproxima de mim e pergunta o que eu estou anotando no caderno, e eu digo que escrevo tudo o que eles estão fazendo, ao que ele imediatamente responde; "Xiii, vou ficar bem quietinho..."

Metade da classe se movimenta para fazer aquela atividade proposta aos pares, usando um pequeno diálogo do livro, em inglês. A outra metade da turma permanece sentada fazendo algo no livro, ou conversando. Enquanto isso, a professora vai trocando os pares que estão fazendo a atividade, ouvindo a pronúncia e interferindo. Alguns ainda permanecem sentados sem fazer a atividade; a professora então, tenta interferir indo perto de cada um e formando novos pares para os que não praticaram; nem todos fazem. Aquele aluno muito agitado continua a perturbar os outros e não faz a atividade proposta, até que acabou o tempo.

A professora promove uma espécie de correção de atividade do livro, repetindo frases do exercício. Volta a tocar a música de início da aula; os alunos cantam seguindo a leitura das palavras no livro, no entanto, a metade não faz, pois estão bastante desanimados.

\section{AULA 6 (Nível: $1^{\text {a }}$ série ou $2^{\circ}$ ano)}


Nesta sala são apenas doze alunos; a professora explica que houve um acordo entre a escola I.S. e o instituto de idiomas English Center, para que os alunos fossem divididos por quantidade e não por nível lingüístico, já que eram todos praticamente iniciantes no estudo da língua.

A aula é iniciada com uma música, mas nem todos participam, pois estão muito agitados; um aluno chega atrasado e entra de repente, agitando mais ainda a turma. Todos falam bastante alto.

Iniciam um jogo de vocabulário utilizando cartões com figuras. Trata-se de uma revisão de palavras já conhecidas de lições anteriores; meninos contra meninas fazem mímicas para reconhecer a palavra. Eles se agitam bastante, gritam, mas participam também. Há sempre muita reclamação de injustiça na pontuação.

A próxima atividade é no livro, com uma colagem de adesivos. Ouvem uma música com referência à figuras do livro, a professora coloca alguns cartazes na lousa com o vocabulário diferente, de modo a confundi-los um pouco, mas a maioria acha muito fácil. Muitos terminam muito antes, porque não esperam ouvir os comandos da música e já fazem e dizem que é fácil demais.

Reparo que na acomodação da sala, todos escolheram seus lugares, organizados em fileiras aos pares; formaram uma fileira apenas de um lado da sala. Apenas uma menina senta-se sozinha do outro lado da sala, na última carteira, e ali permanece até o fim da aula.

A próxima atividade é de listening para completar algo no livro. Ao dar os comandos, a professora mistura inglês e português, preferindo na maioria das vezes, português. Ex: "Nós vamos listen e match neste exercício.” Nesta atividade eles devem ouvir e ligar o personagem à fruta que ele gosta. A primeira vez que ouviram, reclamaram muito dizendo que não haviam entendido nada, ficando muito agitados por isso. A professora coloca de novo e vai parando em cada item, colocando as respostas na lousa com o auxílio dos cartazes. Continuam bastante agitados, mas fazem a atividade. Nesse momento, a professora vai passando entre todos os alunos vendo a atividade de cada um. A aluna sozinha não foi percebida ainda, mas continua a seguir todas as instruções.

A próxima atividade é anunciada: “Books closed.” A professora elícita as respostas, através de um cartaz com personagens, a seguinte frase: "Do you like...?”, dizendo que esse é o jeito para se perguntar se alguém gosta de alguma coisa. Fazem exercício de repetição oral muitas vezes, repetindo mais fino mais grosso, mais alto, mais baixo. Os alunos ficam mais agitados ainda. 
Começam uma atividade para treinar a pergunta: "Do you like...?” O aluno mais agitado é chamado Para um jogo onde deve adivinhar qual é a fruta ou comida do cartaz; o aluno então, joga o cartaz para cima, grita, agita toda a sala, ao que a professora diz: "Marquinhos, para de falar..."

Durante todas as atividades de jogo, a disputa é bastante acirrada entre meninos e meninas, sempre. Um comando constantemente repetido é "Girls first.". Percebo que eles têm muitos problemas achando que sempre há injustiça, porque a professora é que escolhe as participações, porque ela não vê que alguns sopram as respostas, etc. A aluna sozinha não participou ainda nenhuma vez, a professora ainda não a chamou. A pergunta do game, é sempre repetida de forma completa, muitas e muitas vezes, e se eles não completam a estrutura, a professora insiste para que falem a frase toda. Em alguns momentos, o barulho aumenta muito, com assobios, gritos, batidas na carteira, etc.

Quase no final da aula, a professora percebe a aluna no fundo da classe e pede que ela faça a pergunta do jogo. Ela exita, mas fala bem baixinho, timidamente.Ao terminar a aula, todos saem bastante agitados.

\section{AULA 7 (Nível: $2^{\mathrm{a}}$ série ou $3^{\circ}$ ano)}

Os alunos estão bastante agitados, gritando, jogando-se no chão, dando empurrões, apesar da presença da professora. Depois de esperar algum tempo para que eles se quietem um pouco, ela os cumprimenta em inglês, mas logo em seguida a bagunça recomeça, e ela apaga a luz. Parece que esse é um sinal combinado de pedido de silêncio urgente, no entanto a maioria parece ignorar a situação. São 20 alunos em sala de aula.

A professora dispõe os alunos em fileiras duplas, que já completa todo o espaço da sala, pois elas não são muito amplas. Enquanto ela fala, em sua maioria, os alunos falam junto e alguns gritam. Ela coloca um CD para tocar enquanto eles devem pegar o livro. A música começa e a professora pede que os meninos cantem a parte da pergunta e as meninas respondam; depois há uma troca. Eles participam com bastante motivados. Algumas vezes a professora repete a letra da música usando uma técnica de fazer os tons variados. Eles parecem gostar, mas continuam muito agitados. O vocabulário da música é sobre "What's for dinner?"

A professora começa a explicar a próxima atividade em português; trata-se de uma colagem com adesivos no livro junto com um listening. Eles têm muita dificuldade em esperar ouvir o listening para depois colar o adesivo. Começam a colagem sem esperar a ordem do listening. Nesse momento acontece um problema: um aluno retruca com uma espécie de xingamento 
(cocô). A professora para toda a atividade e repreende o aluno energicamente. A maioria participa, porém alguns alunos (5 meninos) continuam falando muito alto e brincando todo o tempo. As meninas dizem, reclamando com eles: "Tem gente aqui... Vocês estão fazendo a gente passar vergonha."

Nesse momento, a professora reage colocando um dos alunos gritões para fora da sala dizendo que ele ficará ali no corredor por cinco minutos, ao que ele retruca: "Só cinco, hein! Já estou contando no relógio..." O aluno continua a fazer muito barulho no corredor; a professora interfere novamente.

A professora inicia outra atividade no livro, mas muitos dizem que já fizeram aquele exercício e ela diz que esses então farão outra coisa. Ela coloca uma música do CD didático ao fundo, enquanto fazem a atividade. Quem termina a atividade, ou quem já tinha feito, ela indica outra atividade em um livro só de exercícios, parece-me um livro de atividades para casa. Ela vai passando entre as carteiras para verificar uma atividade que me parece que foi uma tarefa de casa. Eles se agitam muito, saem do lugar e gritam mais por causa de algumas diferenças entre os livros, ao que ela reage usando o recurso de apagar a luz. Um aluno que gritava e se jogava no chão, é posto para fora da sala também, nesse momento. Diz para outro aluno: "Bruno, você tem dois seconds pra sentar: one, two. Porque você tem muita coisa pra fazer!" O primeiro aluno a sair da sala, volta por si mesmo e ela o recebe normalmente. Ela continua a dar vistos nessa atividade do livro. Logo em seguida ela chama o segundo aluno colocado lá fora, mesmo antes dos cinco minutos.

Nesse momento, parecem um pouco mais calmos e continuam a fazer uma atividade no livro, quando uma menina pergunta se pode ajudar um colega. Ela responde que sim e solicita para que outra aluna também ajude alguém. Há um aluno com a mão levantada há muito tempo, mas ela não percebe, pois está passando entre as carteiras dando vistos. Finalmente, ao perceber, atende-o quanto a uma dúvida do exercício. Ela continua passando entre as carteiras agora ajudando-os no exercício; alguns outros alunos que já terminaram, também ajudam os colegas. A maioria parece mais tranqüila, pintando um desenho no livro; mas alguns reclamam que não querem pintar dizendo que não farão isso.

Quando a professora anuncia que é o momento de guardar o livro, eles ovacionam. Nesse momento alguns alunos correm pela sala e até sobem nas carteiras enquanto ela conversa com alguns de costas. Duas alunas aproximam-se de mim para perguntar se eu também sou do English Center, querendo saber o que eu estava fazendo ali. Depois quiseram ver a quantidade de coisas que eu havia escrito sobre eles. 


\section{AULA 8 (Nível $4^{\text {a }}$ série ou $5^{\circ}$ ano)}

O professor desta turma está participando de um conselho de classe e alguém vem avisar que ele vai atrasar um pouco, no entanto, depois de alguns minutos vem outra pessoa, que me parece ser uma monitora da escola, para estar com eles.

Os alunos estão muito tumultuados, fazendo muita bagunça, gritando e correndo pela sala. Alguns saem para irem ter aula de inglês em outra sala, porque a turma é dividida em níveis diferentes, mas logo voltam, porque o outro professor também não está na sala.

A pessoa que estava com eles pede que eu me apresente; nesse momento tenho a oportunidade de dar uma olhada no material deles, livro texto com algumas atividades e livro só de exercícios. Uma das alunas me conta que acha que a turma dela é muito bagunceira e por isso não aprendem quase nada, segundo ela.

Depois de algum tempo, a monitora reage bastante nervosa e resolve distribuir livros de leitura para todos e diz que eles deverão escrever a história que leram e entregar para ela; diz também que irá marcar o nome de quem não obedecer a ordem dada. Demoram um pouco a acatar, mas a maioria acaba obedecendo.

\section{AULA 9 (Nível $7^{\mathrm{a}}$ série ou $8^{\circ}$ ano)}

Ao chegar, o professor já está em sala. Ele diz que as avaliações que fizeram na aula anterior já estão corrigidas e que ele as entregará comentando-as com cada aluno individualmente. Pede que peguem o livro e que façam determinado exercício; parece-me um assunto antigo. Ele explica o que se espera em cada um dos exercícios e diz que poderão fazê-los em duplas, se quiserem. A maioria senta-se em duplas e passa a fazer a atividade tranquilamente.

Enquanto isso, o professor chama alguns alunos em sua mesa e mostra a prova corrigida, comentando-a. Muitas vezes é interrompido, pois surgem dúvidas, e ele para todas as vezes e explica em cada dupla.

Quando ele solicita que façam determinado exercício, um aluno retruca: "O bimestre acabou... Por que temos que fazer isso?" Ao que ele responde: "O bimestre sim, mas as aulas, não. Posso mudar as notas de vocês a qualquer hora."

Ao anunciar que deverão fazer determinada atividade, diz que deverão terminar em 20 minutos, mas os alunos dizem que precisarão de 30 minutos, no mínimo. Nesse momento estabelece-se uma certa tensão e cada um argumenta um pouco, até que fica estabelecido 25 minutos para o término do exercício. Nesse momento, um dos alunos sentado mais ao fundo 
da sala pede uma explicação ao professor e este vai até lá para atendê-lo e percebe que o rapaz está com um fone de ouvido escutando música. O professor solicita que tire o fone imediatamente (essa é uma regra da escola); o aluno então, tenta negociar dizendo que está fazendo o exercício solicitado com interesse, pois do contrário, não teria pedido explicação, ao que o professor gentilmente responde: "Isso não é negociável."

Nesse momento, um dos alunos que está sentado bem próximo a mim e que já havia conversado sobre o meu papel como pesquisadora ali, diz: "Isso é importante você anotar aí; o teacher sempre dialoga com a gente... por isso ele tem que ficar no próximo semestre."

Tive a oportunidade de observar o material didático utilizado por eles: consta de um livro texto e um livro de exercícios, bastante tradicionais no mercado de didáticos de ensino de língua estrangeira.

Muitos alunos solicitam a ajuda do professor para resolver determinado exercício e ele o faz individualmente, indo no lugar de cada um. Os alunos reclamam que não sabem resolver determinado exercício; têm muitas preocupações gramaticais, e querem sempre se remeter a alguma regra, repetindo-as algumas vezes.

O professor solicita que duas alunas venham até a lousa para corrigir o exercício que estão com mais dificuldade; ele pede que os demais copiem a resposta. Alguém pergunta: "Tem que ser igual?" Ele responde que sim.

Houve alguns momentos em que os alunos estavam um pouco mais agitados ou falando mais alto e percebo que o professor tem alguns códigos com eles, do tipo, apagar a luz para diminuir o barulho, colocar o dedo na ponta do nariz, indicando que está aguardando silêncio para falar.

Durante a realização desses exercícios, o professor continuou chamando um por um para comentar a prova corrigida, mas não houve tempo de todos virem. Continuarão na próxima aula.

\section{AULA 9 (Nível: $6^{\mathrm{a}}$ série ou $7^{\circ}$ ano)}

Os alunos chegam à sala bastante agitados, mas sentam-se rapidamente; percebo que estão ansiosos com alguma coisa. A sala está bem cheia. É dia de avaliação de writing. A professora anuncia o teste entregando as folhas timbradas, explicando as duas opções que terão para fazerem suas redações em inglês: "What do you think your life will be when you are 20? Write a text about your prediction" e a outra, "Your Best friend is not being well in school. Write him/her an e-mail giving an advice." 
O professor explica que deverão escrever textos de 80 a 100 palavras, dentro de um dos temas solicitados, com o melhor de correção gramatical e ortográfica que puderem. Dá essas explicações em inglês e a maioria compreende bem; alguns poucos solicitam a ajuda para saberem o devem fazer e ela explica individualmente em português. Uma aluna procura individualmente pela professora, parecendo bastante nervosa; disse que não conseguia entender nada do que estava escrito na proposta dos temas; a professora então, traduz as duas propostas.

Um aluno diz em voz alta: "Não sei como escreve faculdade." E o seu amigo responde: "Improvisa." E a professora diz: "Try to use a different Word!"

Muitos tiveram bastante dificuldade para começar a escrever e depois, reclamavam que não conseguiam chegar ao limite mínimo de palavras; contavam e contavam o tempo todo para ver se tinham atingido o mínimo.

A professora explicou-me que para dar os conceitos aos testes, ela considera estrutura gramatical utilizada, vocabulário temático e coerência temática. Li algumas redações que estavam relativamente bem produzidas, dentro desse padrão sugerido.

No final da aula, quatro alunos não conseguiam chegar no limite mínimo de palavras. Estavam muito nervosos. Pouco a pouco foram desistindo e entregando os testes; um deles fica, mesmo depois de dado o sinal; percebi que estava realmente muito nervoso, até que de repente ele começa a chorar muito, inconformado. A professora vai até ele tentando acalmá-lo dizendo: "Calma, o máximo que vai acontecer é você ficar de recuperação..." Ao final ele desiste e sai muito triste. A professora conta que esse é um aluno excelente aluno, muito esforçado, que sempre faz todas as atividades em sala, mas que não consegue ter uma boa atuação em nenhuma avaliação de inglês.

\section{AULA 10 (Nível: $2^{\text {a }}$ série ou $3^{\circ}$ ano)}

Os alunos chegam para a aula aos poucos; havia sido o intervalo e muitos não subiram ao sinal. Demoram quase vinte minutos até que todos cheguem para começar a aula. A professora aguarda.

A professora introduz a aula com uma música; muitos fazem brincadeiras com a canção, como se estivessem achando a canção muito infantil. A música é tocada por duas vezes.

A professora dá alguns comandos em inglês, com bastante demonstração gestual, ao que a maioria compreende e obedece. Os alunos estão dispostos em grupos de quatro em cada mesinha. Um aluno que estava muito agitado é retirado de seu grupo e colocado sozinho em uma outra mesa mais afastada durante toda a aula. 
A professora tenta dar as instruções do jogo que fará em seguida, mas todos estão muito agitados e dizem não ter o material que ela solicita, papel e lápis. Pede que copiem tudo o que ela fizer na lousa. Ela desenha um grande retângulo.

Nesse momento, a classe se agita muito, com alunos fora do lugar, gritando por causa que estão emprestando o material um para o outro. A professora interfere bastante brava com o barulho, pedindo que sentem imediatamente. A maioria acata.

Demoram maios ou menos uns dez minutos para fazerem os quadros para o jogo. Trata-se de jogo do bingo. Ela dita as palavras e eles devem escrever nos seus quadros aleatoriamente; depois de alguns minutos ela escreve na lousa nos quadros que já desenhou. Houve alguns problemas e reclamações com um copiando do outro, pois era para que cada um escondesse do outro.

Ao escrever na lousa, ela solicita: "How do you spell...? Poucos soletravam em inglês, a maioria fazia em português.

Depois de composta a tabela que eles mesmos prepararam ela explica que ganha quem fizer primeiro a linha do meio. Alguém diz: "E o que vamos ganhar?" Alguém responde: "A vitória." E alguém retruca: "Mas a gente precisa aprender a perder..."

Os alunos estavam bastante animados com a competição. Quiseram disputar até o $5^{\circ}$ lugar... Ao final, gritaram, subiram nas carteiras e a professora apagou a luz contando um, dois, três, até que todos fizessem silêncio.

\section{AULA 11 (Nível: $6^{\text {a }}$ série ou $7^{\circ}$ ano)}

Os alunos entram na sala um pouco agitados, com um ar de cansado. Parece que estão vindo de alguma aula de esportes. Todos estão muito ansiosos e falam ao mesmo tempo pedindo para ver as provas. A professora diz que não trouxe as provas e diz que pode adiantar que foram muito mal na avaliação, muito abaixo do esperado e que vão conversar a respeito só na próxima semana, já com as médias feitas, pois o que já está feito acabou.

A professora anuncia que vão fazer um jogo, dividindo a turma em grupos de quatro. Ela explica o jogo; vão precisar do livro e do livro de exercícios; diz que cada grupo deve fazer quatro perguntas sobre a unidade 1, quatro sobre a unidade dois e quatro sobre a unidade três, dando a indicação das respectivas páginas de cada unidade solicitada. Montarão um tabuleiro, posteriormente.

Ela passa pelos grupos verificando se entenderam o solicitado para a confecção do jogo. Os grupos se mantém bastante agitados, com brincadeiras, gritos, jogando objetos, etc. Nesse 
momento, dois alunos foram colocados para fora da sala e ela conversa com eles durante algum tempo no corredor.

Enquanto isso, os grupos começam a trabalhar na atividade aos poucos. Os dois alunos não voltam mais para a aula; depois soube que eles foram para algum outro lugar na escola fazer exercícios no livro.

Ao construir as perguntas, eles se mantiveram dentro dos temas solicitados (unidades do livro indicadas) e também as estruturas das unidades indicadas, como foi solicitado. Um dos grupos termina antes e começa a atrapalhar; a professora interfere. Um outro grupo, que já estava com alguns problemas disciplinares, faz a seguinte pergunta, em tom nitidamente provocativo, entre as questões escolhidas para o jogo: "Do you use toillete paper?" A professora interfere dizendo que não aceita, alegando não pertencer ao vocabulário solicitado. Antes de dispensá-los da aula ela solicita que tragam materiais como cartolina e lápis especiais para terminarem o jogo. 


\section{ANEXOS}

\section{Decreto do Serra que afeta a educação em língua estrangeira http://www.jusbrasil.com.br/legislacao/819016/decreto-54758-09-sao-paulo-sp}

JOSÉ SERRA, GOVERNADOR DO ESTADO DE SÃO PAULO, no uso de suas atribuições legais, Considerando o disposto na Lei federal $n^{\circ}$ 9.394, de 20 de dezembro de 1996, que fixa diretrizes e bases da educação nacional;

Considerando as inovações introduzidas nos currículos do ensino fundamental e médio das escolas da rede estadual;

Considerando a importância de se assegurar aos alunos da rede pública estadual a oportunidade de desenvolver e ampliar novas formas de expressão;

Considerando a necessidades de se propiciar aos alunos instrumento de acesso às novas tecnologias e ao mercado de trabalho que exige cada vez mais o domínio de um idioma estrangeiro; e Considerando a oferta obrigatória pela escola e de matrícula facultativa para o aluno do ensino da língua espanhola, a partir de 2010, Decreta:

Artigo $1^{\circ}$ - Os Centros de Estudos de Línguas - CELs, criados no âmbito da rede estadual de ensino pelo Decreto $\mathrm{n}^{\mathrm{o}} 27.270$, de 10 de agosto de 1987, ficam disciplinados nos termos deste decreto.

Artigo $2^{\circ}$ - Os Centros de Estudos de Línguas - CELs de que trata o artigo $1^{\circ}$ deste decreto têm por finalidade proporcionar aos alunos das escolas públicas estaduais a possibilidade de aprendizagem de língua estrangeira moderna, em caráter opcional, de livre escolha da clientela escolar.

Parágrafo único - Os cursos de língua estrangeira moderna oferecidos nos centros de que trata o "caput" deste artigo destinam-se aos alunos do ensino fundamental, a partir da $6^{\text {a }}$ série, e aos do ensino médio.

Artigo $3^{\circ}$ - O ensino de língua estrangeira moderna nos Centros de Estudos de Línguas CELs, deverá enfatizar o domínio da linguagem oral ou o seu caráter instrumental e de acesso à cultura de outros povos e civilizações, como mecanismo de enriquecimento curricular. Artigo $4^{\circ}$ - A língua estrangeira moderna que integra obrigatoriamente o currículo escolar do aluno poderá ser cursada por ele também nos Centros de Estudos de Línguas - CELs, dado o caráter de enriquecimento curricular de que se reveste o seu ensino nessa unidade.

Artigo $5^{\circ}$ - Esgotada a capacidade dos Centros de Estudos de Línguas - CELs de atender à demanda de alunos interessados na aprendizagem de uma língua estrangeira moderna opcional, a Secretaria da Educação poderá contar com instituições públicas e privadas que 
tenham por finalidade o ensino de idiomas, devidamente credenciadas para esse fim, observadas as disposições legais pertinentes.

Artigo $6^{\circ}$ - A Secretaria da Educação poderá baixar normas complementares para o cumprimento do disposto neste decreto.

Artigo $7^{\circ}$ - Este decreto entra em vigor na data de sua publicação, revogadas as disposições em contrário, em especial o parágrafo único do artigo $1^{\circ}$, e os artigos $2^{\circ}$ e $3^{\circ}$ do Decreto ${ }^{\circ}$ 27.270, de 10 de agosto de 1987.

Palácio dos Bandeirantes, 10 de setembro de 2009

\section{JOSÉ SERRA}

Publicado em: 11/09/2009 


\section{Propagandas dos institutos de idiomas para a terceirização}

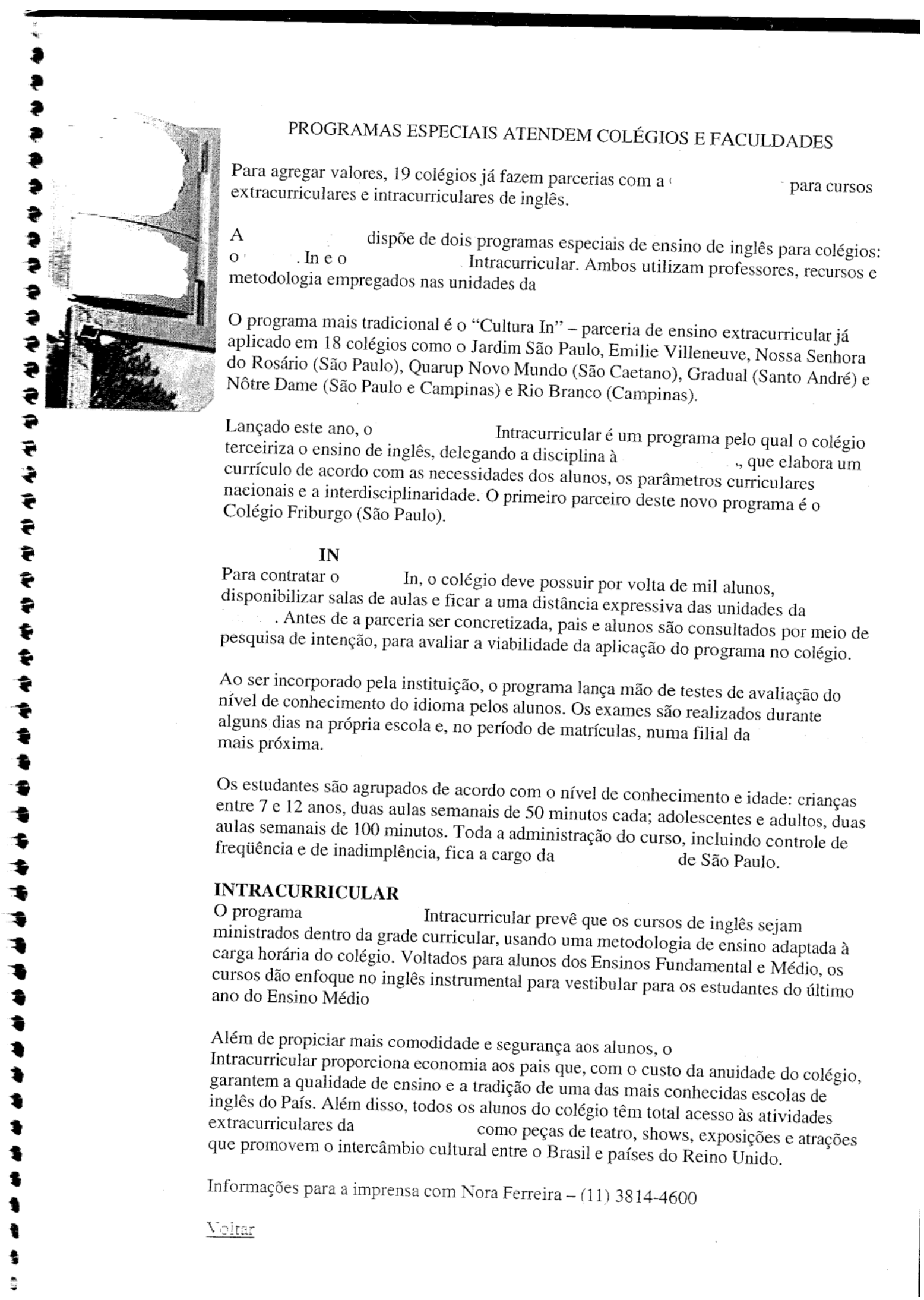


Convênio Escola- - $\quad$ EDUCA+

O programa de ensino de idiomas completo para a sua escola

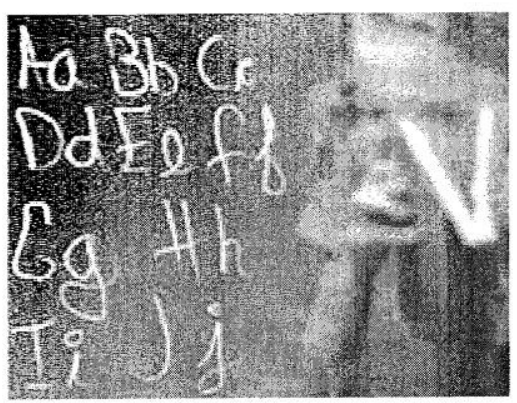

As exigências do mercado

Em um mercado cada vez mais

competitivo, como o de educação,

destacam-se as Instituiç̃os de Ensino que

oferecem mais e melhores diferenciais,

através de atividades extracurriculares e cursos adicionais. Afinal, os pais procuram as escolas mais completas, que ofereçam o maior mix de aprendizado em uma boa relação custo $X$ benefício.

\section{A força da marca}

o : é reconhecidamente uma das marcas mais fortes no setor de educação, em nível nacional. Possui a maior média de alunos por escola, em todo o país.

\section{(C) Metodologia : Ensino de Idiomas Pensado Para a Vida}

No $\quad 0$ aluno aprende o idioma naturalmente, da mesma maneira como aprendeu a falar Português. A proposta pedagógica do tem como base a comunicação e o uso constante do idioma em situações reais do dia-a-dia.

Com suporte de um material didático exclusivo, feito sob medida para o público brasileiro, o aluno do aprende a se comunicar em Inglês e Espanhol ouvindo músicas, assistindo a filmes, encenando situações cotidianas, participando de atividades e de jogos interativos.

O aprendizado gramatical é inserido neste contexto e é absorvido pelo aluno com o incentivo de professores dinâmicos e criativos, treinados especialmente para este tipo de aprendizado e para a metodologia Todos os professores e coordenadores pedagógicos da Rede passam por treinamentos e reciclagens constantes, além de participarem de palestras e workshops, bem como da já tradicional Conferência de Ensino que reúne profissionais de ensino de idiomas de todo o país.

A combinação certa entre bons professores, um excelente material e uma metodologia dinâmica e inovadora oferece aos alunos o melhor em um ensino de idiomas que, em todos os momentos, é pensado para a vida.

\section{EDUCA+}

Uma grande rede de ensino. Dois formatos de negócios. A certeza do sucesso.

A melhor escola de idiomas dentro da sua escola

Formatos de parcerias para Instituições de Ensino: 


\section{Extracurricular}

Um verdadeiro posto avançado , instalado nas dependências de sua Instituição de Ensino para melhor atender aos seus alunos. Confira as vantagens no formato Extracurricular:

- Mais segurança, conforto e conveniência: com aulas na própria Instituição de Ensino, os alunos não perdem tempo nem têm custos adicionais com transporte. Para os pais, fica a certeza de que seus filhos estão seguros, no próprio ambiente da escola.

- Fidelização: quanto maior o valor agregado ao curso oferecido por sua Instituição de Ensino, maior o grau de retenção de alunos e, consequëntemente, maior rentabilidade para o seu negócio.

- Equipe de ensino formatada para atender às necessidades específicas de seus alunos.

\section{Convênios}

Através deste formato, alunos da sua Instituição de Ensino têm descontos especiais nos cursos : ministrados na Unidade mais próxima. Consulte as condições especiais oferecidas pelo: a as alunos conveniados.

Educa +

Um programa completo e intercambiável

No ., os programas educacionais para Instituições de Ensino são multifuncionais e intercambiáveis. Isso significa que a Escola pode optar não apenas por um dos formatos acima descritos (Extracurricular e Convênios), mas aplicar ambos, dependendo da necessidade de seus alunos.

Desta forma, a Instituição poderá oferecer cursos de idiomas tanto em seu ambiente físico (extracurricular) quanto na Unidade (Convênio). Fale com nossos consultores e monte o seu plano exclusivo de parceria.

- Metodologia comunicativa e material didático exclusivo, feito sob medida para o aluno brasileiro. O material é complementado com CDs de áudio e de multimídia, além de atividades específicas na Internet.

- Atividades extracurriculares, para apoio ao ensino em sala de aula: os alunos realmente vivenciam a cultura dos paises das línguas inglesa e espanhola.

- Suporte pedagógico: um coordenador de ensino sempre estará à disposição de sua escola. O é a única rede de ensino de idiomas cuja autora dos materiais didáticos é também diretora de ensino e vice-presidente de toda a Rede, o que comprova a orientação pedagógica da Empresa.

- Os melhores professores: treinamentos, workshops, palestras, conferências e reciclagens constantes. O professor . está sempre atualizado sobre as mais modernas técnicas de ensino.

- Terceiro Setor: O é reconhecidamente uma empresa cidadã, cujo foco de atividades no Terceiro Setor é voltado para a educação infantil, através da Fundação e de outras atividades, como a parceria com a Secretaria de Educação do Estado de São Paulo (Projeto Escola da Família) e outras associações, como o Instituto Ethos.

- 30 anos de experiência no ensino de idiomas.

- 372 Unidades em todo o Brasil.

- Mais de 375 mil alunos, de todas as idades 
nas escolas

Sua escola pode ter os mesmos cursos de inglês e espanhol oferecidos no : Veja só quantas vantagens o pode trazer para seus alunos:

- Eficácia: inglês e espanhol com metodologia comprovadamente eficaz, dinâmica e atraente como nas unidades. Nas escolas, o ? verece cursos de inglês da Classe de Alfabetização ao Ensino Médio e cursos de espanhol da 5. a série do Ensino Fundamental até a 3. a série do Ensino Médio.

- Economia: os mesmos cursos oferecidos nas unidades são oferecidos nas escolas por preços bem mais acessíveis e com a mesma qualidade, inclusive com emissão de certificados.

- Qualidade: em grupos reduzidos, os alunos aprendem com professores do ou da própria escola, treinados e supervisionados pela equipe do

- Conforto e segurança: sem precisar se deslocar, os alunos têm aulas dentro da própria escola, integradas ou não à grade curricular.

Oferecemos fitas de vídeo, CD-ROMs e, é claro, planos de aulas e conjunto de livros para os professores. De acordo com o número de alunos matriculados, sua escola recebe gratuitamente uma Estação Multimídia composta por:

. computador

. TV de 29"

videocassete

- amplificador de som

2 caixas acústicas 


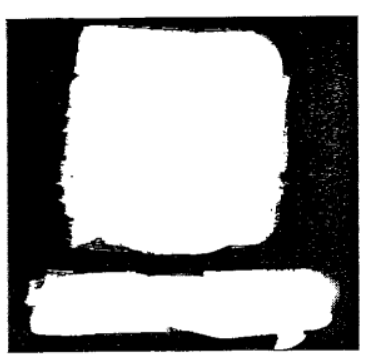

Faça uma parceria com quem fala vários idiomas e tem mais de 30 anos de experiência na área educacional.

De preferência, alguém que ofereça cursos de idiomas no Brasil e vivência no exterior, e que tenha 20 unidades estrategicamente localizadas. Alguém que esteja aberto à comunidade de professores, oferecendo cursos para seu desenvolvimento e aprimoramento. Alguém que preste assessoria no ensino de Inglês em escolas regulares, com eficiência, metodologia de vanguarda, recursos tecnológicos avançados e com a seriedade que o mercado exige. 


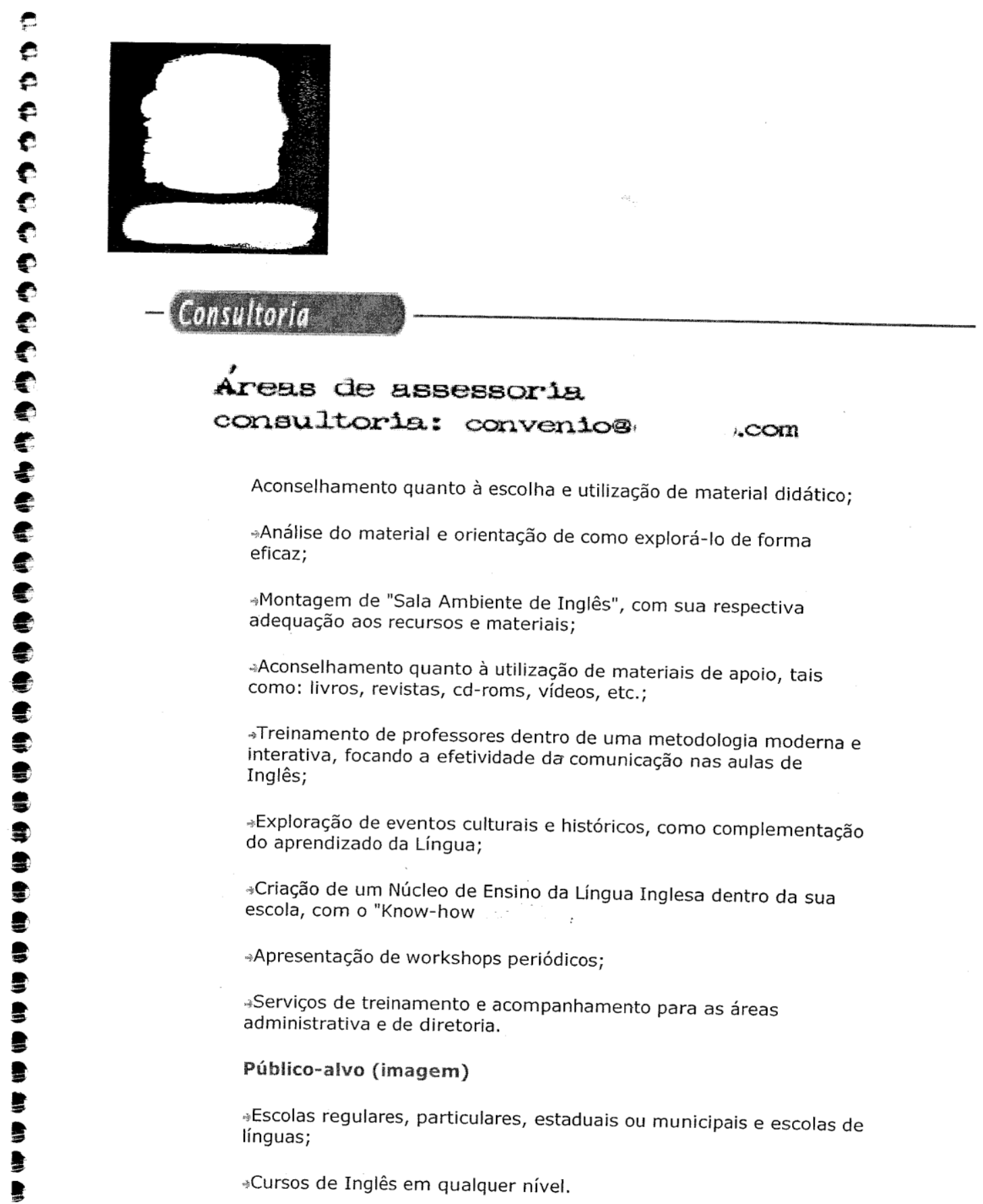

